science for a changing world

\title{
Estimates of Natural Ground-Water Discharge and Characterization of Water Quality in Dry Valley, Washoe County, West-Central Nevada, 2002-2003
}

Scientific Investigations Report 2004-5155

Prepared in cooperation with WASHOE COUNTY

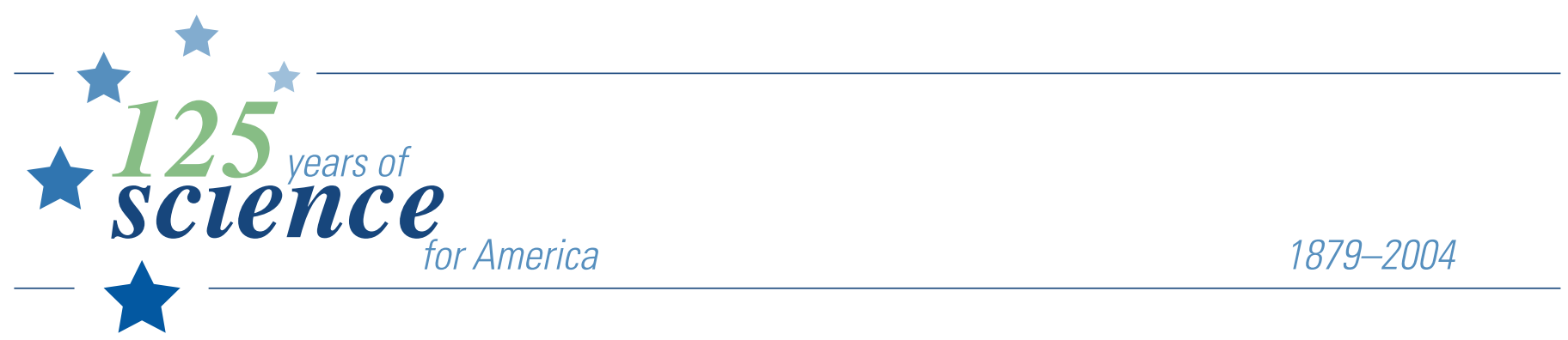

U.S. Department of the Interior U.S. Geological Survey 
(Back of Cover) 


\section{Estimates of Natural Ground-Water Discharge and Characterization of Water Quality in Dry Valley, Washoe County, West-Central Nevada, 2002-2003}

By David L. Berger, Douglas K. Maurer, Thomas J. Lopes, and Keith J. Halford

U.S. GEOLOGICAL SURVEY

Scientific Investigations Report 2004-5155

Prepared in cooperation with

WASHOE COUNTY 


\title{
U.S. DEPARTMENT OF THE INTERIOR GALE A. NORTON, Secretary
}

\author{
U.S. GEOLOGICAL SURVEY \\ CHARLES G. GROAT, Director
}

Any use of trade, product, or firm names in this publication is for descriptive purposes only and does not imply endorsement by the U.S. Government

For additional information contact:

\section{District Chief}

U.S. Geological Survey

333 West Nye Lane, Room 203

Carson City, NV 89706-0866

email: GS-W-NVpublic-info @ usgs.gov

http://nevada.usgs.gov
Copies of this report can be purchased from:

U.S. Geological Survey

Information Services

Building 810

Box 25286, Federal Center

Denver, CO 80225-0286 


\section{CONTENTS}

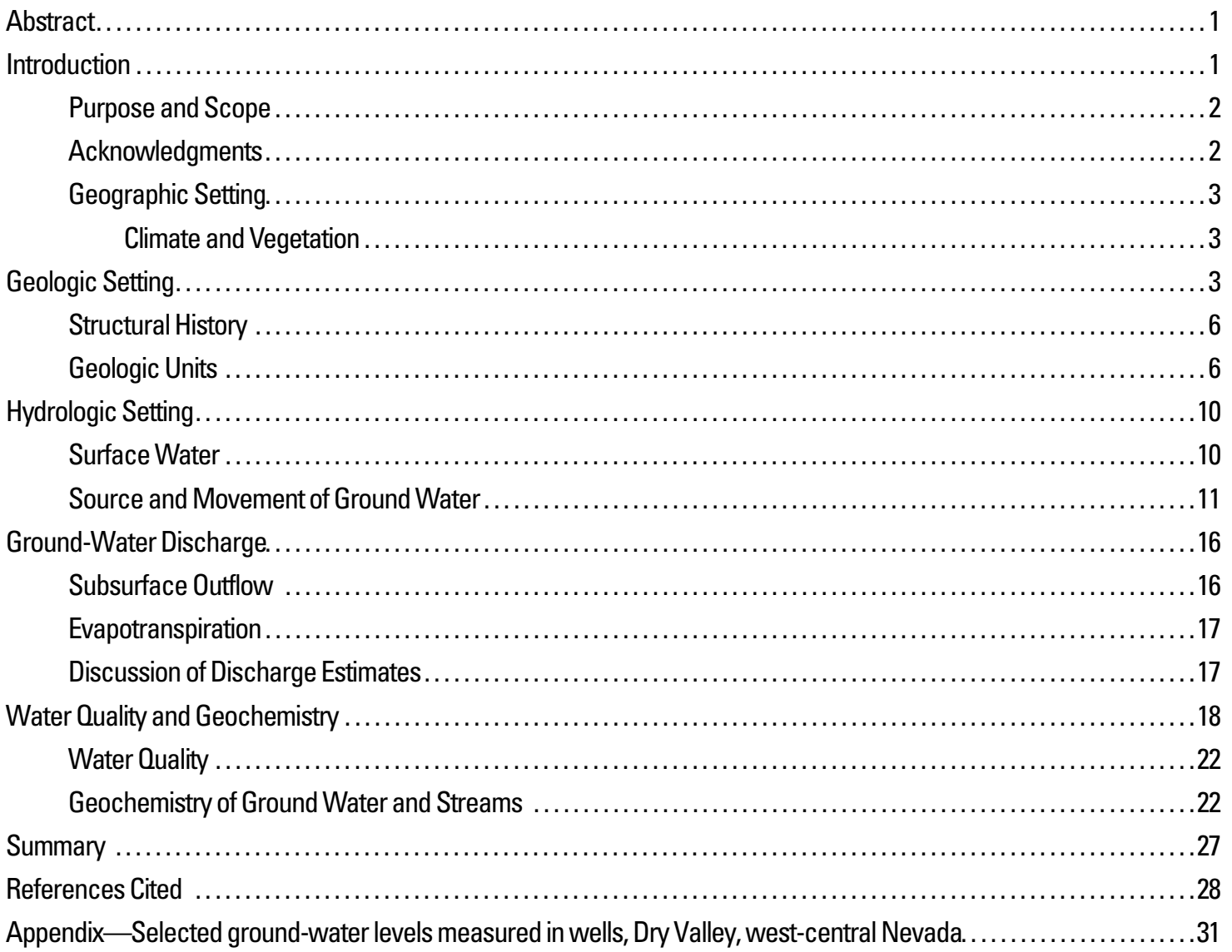

FIGURES

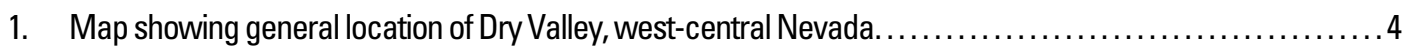

2. Map showing geographic features of study area, distribution of geologic units and faults, and locations

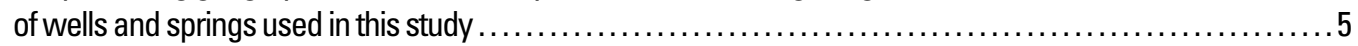

3. Map showing distribution of geologic units and faults in western part of the study area. $\ldots \ldots \ldots \ldots \ldots \ldots \ldots$

4. Graphs showing example of borehole-geophysical and lithological logs collected from a borehole where well sites 14,15 , and 16 are installed along the State line, Dry Valley, west-central Nevada............... 9

5. Graphs showing time-distance curves and resultant velocity-depth cross section for seismic-refraction

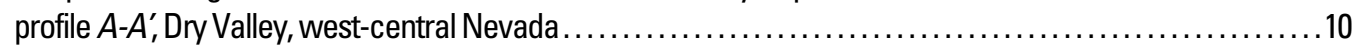

6. Graphs showing water-level fluctuations for 2002 through 2003 in selected wells in Dry Valley, west-central

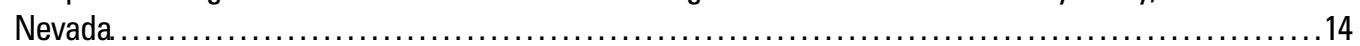

7. Graph showing hydrogeologic cross section $B-B^{\prime}$ near the mouth of Dry Valley, west-central Nevada. ......17

8. Satellite imagery showing area of phreatophytic vegetation and shallow depth to ground water ............18

9. Graph showing ratios of major ion chemistry for water sampled in Dry Valley, west-central Nevada ........23

10. Graph showing chloride as a function of dissolved-solids concentration, Dry Valley, west-central

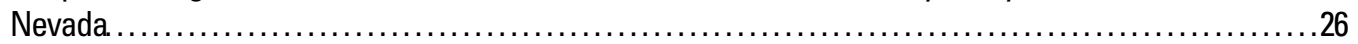

11. Graph showing relation of deuterium to oxygen-18 in sampled ground water and springs in Dry Valley, west-central Nevada. 
TABLES

1. Site number, location, well construction, and type of data available for well and spring sites, Dry Valley,

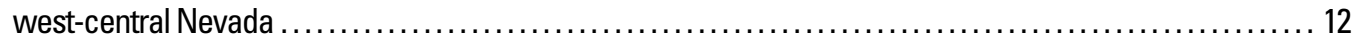

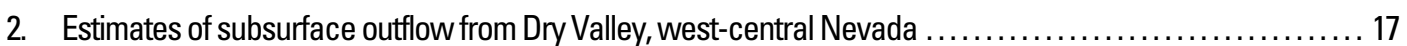

3. Estimates of ground-water discharge by evapotranspiration in areas of phreatophytic vegetation,

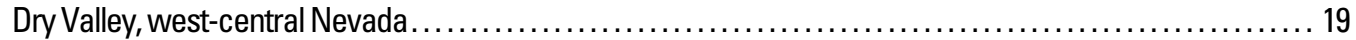

4. Estimates of natural ground-water discharge from Dry Valley, west-central Nevada .................. 19

5. Results of chemical analyses for water samples from selected well and spring sites, Dry Valley,

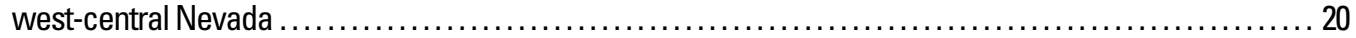

6. Comparison of selected inorganic constituents for primary and secondary drinking-water standards,

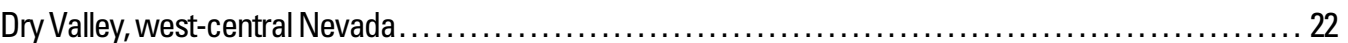

7. Saturation indices of calcite for ground water in Dry Valley, west-central Nevada $\ldots \ldots \ldots \ldots \ldots \ldots \ldots \ldots \ldots \ldots \ldots \ldots \ldots$

\section{CONVERSION FACTORS, VERTICAL DATUM, AND ABBREVIATED UNITS}

\begin{tabular}{rll}
\hline Multiply & By & To obtain \\
\hline acre & 4,047 & square meter \\
acre-foot (acre- $\mathrm{ft})$ & 0.001233 & cubic hectometer \\
acre foot per year (acre- $\mathrm{ft} / \mathrm{yr})$ & 0.001233 & cubic hectometer per year \\
cubic foot per second $\left(\mathrm{ft}^{3} / \mathrm{s}\right)$ & 0.02832 & cubic meter per second \\
foot $(\mathrm{ft})$ & 0.3048 & meter \\
foot per day $(\mathrm{ft} / \mathrm{d})$ & 0.3048 & meter per day \\
foot per second $(\mathrm{ft} / \mathrm{s})$ & 0.3048 & meter per second \\
inch $(\mathrm{in.})$ & 25.4 & millimeter \\
mile $(\mathrm{mi})$ & 1.609 & kilometer \\
square foot per day $\left(\mathrm{ft}^{2} / \mathrm{d}\right)$ & 0.09290 & meter squared per day \\
gallon per minute $(\mathrm{gal} / \mathrm{min})$ & 0.06308 & liter per second \\
square mile $\left(\mathrm{mi} \mathrm{m}^{2}\right)$ & 2.590 & square kilometer \\
\hline
\end{tabular}

Temperature: Degrees Celsius $\left({ }^{\circ} \mathrm{C}\right)$ can be converted to degrees Fahrenheit $\left({ }^{\circ} \mathrm{F}\right)$ by using the formula ${ }^{0} \mathrm{~F}=\left[1.8\left({ }^{\circ} \mathrm{C}\right)\right]+32$. Degrees Fahrenheit can be converted to degrees Celsius by using the formula ${ }^{\circ} \mathrm{C}=0.556\left({ }^{\circ} \mathrm{F}-32\right)$.

Sea level: In this report, "sea level” refers to the National Geodetic Vertical Datum of 1929 (NGVD of 1929, formerly called "Sea-Level Datum of 1929"), which is derived from a general adjustment of the first-order leveling networks of the United States and Canada.

Metric water-quality and geophysical units:

$\mathrm{g} / \mathrm{cm}^{3}$, gram per cubic centimeter $\mu \mathrm{m}$, micrometer $\mathrm{mg} / \mathrm{L}$, milligram per liter permil, part per thousand
mGal, milliGal $\mu \mathrm{S} / \mathrm{cm}$, microsiemens per centimeter at $25^{\circ} \mathrm{C}$ $\mathrm{mL}$, milliliter

Note: English units are used throughout this report, except in instances where a measurement has no common English-unit equivalent. 


\title{
Estimates of Natural Ground-Water Discharge and Characterization of Water Quality in Dry Valley, Washoe County, West-Central Nevada, 2002-2003
}

\author{
by David L. Berger, Douglas K. Maurer, Thomas J. Lopes, and Keith J. Halford
}

\section{Abstract}

The Dry Valley Hydrographic Area is being considered as a potential source area for additional water supplies for the Reno-Sparks area, which is about 25 miles south of Dry Valley. Current estimates of annual ground-water recharge to Dry Valley have a considerable range. In undeveloped valleys, such as Dry Valley, long-term ground-water discharge can be assumed the same as long-term ground-water recharge.

Because estimating ground-water discharge has more certainty than estimating ground-water recharge from precipitation, the U.S. Geological Survey, in cooperation with Washoe County, began a three-year study to re-evaluate the ground-water resources by estimating natural ground-water discharge and characterize ground-water quality in Dry Valley.

In Dry Valley, natural ground-water discharge occurs as subsurface outflow and by ground-water evapotranspiration. The amount of subsurface outflow from the upper part of Dry Valley to Winnemucca and Honey Lake Valleys likely is small. Subsurface outflow from Dry Valley westward to Long Valley, California was estimated using Darcy's Law. Analysis of two aquifer tests show the transmissivity of poorly sorted sediments near the western side of Dry Valley is 1,200 to 1,500 square feet per day. The width of unconsolidated sediments is about 4,000 feet between exposures of tuffaceous deposits along the State line, and decreases to about 1,500 feet ( 0.5 mile) west of the State line. The hydraulic gradient east and west of the State line ranges from 0.003 to 0.005 foot per foot. Using these values, subsurface outflow to Long Valley is estimated to be 50 to 250 acre-feet per year.

Areas of ground-water evapotranspiration were field mapped and partitioned into zones of plant cover using relations derived from Landsat imagery acquired July 8, 2002. Evapotranspiration rates for each plant-cover zone were multiplied by the corresponding area and summed to estimate annual groundwater evapotranspiration. About 640 to 790 acre-feet per year of ground water is lost to evapotranspiration in Dry Valley. Combining subsurface-outflow estimates with ground-water evapotranspiration estimates, total natural ground-water discharge from Dry Valley ranges from a minimum of about 700 acre-feet to a maximum of about 1,000 acre-feet annually.

Water quality in Dry Valley generally is good and primary drinking-water standards were not exceeded in any samples collected. The secondary standard for manganese was exceeded in three ground-water samples. One spring sample and two surface-water samples exceeded the secondary standard for $\mathrm{pH}$. Dry Valley has two primary types of water chemistry that are distinguishable by cation ratios and related to the two volcanicrock units that make up much of the surrounding mountains. In addition, two secondary types of water chemistry appear to have evolved by evaporation of the primary water types. Ground water near the State line appears to be an equal mixture of the two primary water chemistries and has as an isotopic characteristic similar to evaporated surface water.

\section{Introduction}

Increasing population growth in west-central Nevada has resulted in urban expansion to valleys generally north of the Reno-Sparks area (fig. 1). Although the Truckee River provides most of the water to the Reno-Sparks area, ground water is the primary source for the northern valleys. Further development in several of the more urbanized valleys has been limited because additional ground-water resources are not available. Concerns about the availability of good quality ground water to sustain continued growth has led regional water planners to look for additional resources in other valleys that currently are undeveloped.

The Dry Valley Hydrographic Area ${ }^{1}$ (HA), a valley north of the Reno-Sparks area, currently has little ground-water development and is being considered as a potential source area for additional water supplies. Precipitation that falls within Dry Valley is the primary source of ground water. A previous waterresources investigation made in the late 1960's, estimated ground-water recharge to Dry Valley from precipitation to be

\footnotetext{
${ }^{1}$ The U.S. Geological Survey and Nevada Division of Water Resources delineated formal hydrographic areas in Nevada systematically in the late 1960's for scientific and administrative purposes (Cardinalli and other, 1968; Rush, 1968). The official hydrographic-area names, numbers, and geographic boundaries continue to be used in U.S. Geological Survey scientific reports and Division of Water Resources administrative activities. Hydrographic-area boundaries generally coincide with drainage-area boundaries.
} 


\section{Estimates of Natural Ground-Water Discharge and Characterization of Water Quality in Dry Valley, 2002-2003}

about 2,400 acre-ft/yr (Rush and Glancy, 1967, p. 20). This estimate was derived from a reconnaissance-level technique, known as the Maxey-Eakin Method, which estimates groundwater recharge as a function of fixed fractions of precipitation (Maxey and Eakin, 1949, p. 40-41). Rush and Glancy (1967, p. 20) used a 1965 revised version of the precipitation map developed by Hardman $(1936,1965)$ to estimate annual precipitation in Dry Valley to be 44,000 acre-ft.

A statistical-topographic model used to estimate regional precipitation (Daly and others, 1994) indicates that annual precipitation in Dry Valley may be as much as 80,000 acre-ft and the resultant ground-water recharge more than 4 times the estimate of Rush and Glancy (1967). Thomas and Albright (2003), using the chloride mass-balance method, estimate between 1,400 to 4,800 acre-ft/yr of ground-water recharge from precipitation in Dry Valley. Estimates of ground-water recharge based on the mass balance of chloride, in part, is a direct function of the amount of precipitation that is assumed to fall in recharge source areas within a ground-water basin (Dettinger, 1989). Thomas and Albright (2003, p. 7) estimate that nearly 66,000 acre-ft/yr of precipitation falls in the recharge source areas in Dry Valley and is based on a relation between short-term, local precipitation data and regional, long-term precipitation data. Consequently, current estimates of annual ground-water recharge to Dry Valley have a considerable range and are a direct function of the particular precipitation data used in the recharge estimate.

Ground-water discharge can be estimated with much more certainty than ground-water recharge from precipitation (Adar and others, 1988). Processes of natural ground-water discharge; evapotranspiration (ET) and subsurface outflow, typically vary only slightly both aerially and temporally. In contrast, groundwater recharge is unpredictable, particularly in arid and semiarid environments where recharge from precipitation is episodic and often of short duration. For ground-water systems in undeveloped basins, like Dry Valley, long-term average recharge can be assumed to approximate long-term average discharge (Theis, 1940, p. 277). This assumption suggests that natural ground-water discharge from Dry Valley can be equated to ground-water recharge from precipitation and that long-term changes in ground-water storage are negligible (Watson and others, 1975 , p. 342).

In Nevada, ground-water withdrawals from a basin are limited by law to the estimate of perennial yield (NRS 533.271). Perennial yield is defined as "the maximum amount of natural discharge that can be salvaged each year over the long term by pumping without bringing about some undesired result" (Nevada State Engineer, 1974, p. 12). Previous estimates of ground-water discharge in Dry Valley were made by Rush and Glancy (1967), in their reconnaissance-level study that included 11 valleys north of the Reno-Sparks area. Rush and Glancy (1967, p. 33 and 37) estimated natural ground-water discharge from Dry Valley to be about 2,300 acre-ft/yr as ground-water outflow and ET. Assuming that about half the estimated discharge could be salvaged, Rush and Glancy (1967, p. 49) estimated the perennial yield in Dry Valley to be about
1,000 acre-ft/yr. Because no hydrologic data were available in Dry Valley during the investigation, their discharge estimates are based on assumed values of transmissivity, ground-water gradients, and ET rates. Ground-water quality was not assessed because no wells existed in Dry Valley (Rush and Glancy, 1967).

An updated estimate of the amount of natural groundwater discharge and evaluation of water quality will allow for more effective planning of the water resources in Dry Valley and help determine the potential of Dry Valley as a source of ground water for continued regional growth. In the summer of 2002, the U.S. Geological Survey (USGS), in cooperation with Washoe County, began a three-year study to re-evaluate the ground-water resources in Dry Valley, with emphasis on estimating natural ground-water discharge.

\section{Purpose and Scope}

The purposes of this report are to present estimates of natural ground-water discharge and characterize the quality of ground water in Dry Valley. The study area includes that part of Dry Valley that lies entirely in Nevada. Field work began in July 2002 and included; seismic-refraction profiling, installation of monitoring wells and collection of borehole geophysical data, water-level measurements, aquifer tests, mapping of phreatophytic vegetation and geology, and chemical analysis of water sampled from wells and springs.

Ground-water discharge by outflow through the basin fill to Long Valley, Calif., was estimated using Darcy's Law. The estimate was based on modified geologic maps of the area, water levels measured in 23 wells, and two aquifer tests made in May and July 2003. Ground-water discharge by ET was estimated using areas of mapped phreatophytic vegetation and the application of remote sensing techniques for deriving ET rates. Field mapping was enhanced using satellite imagery acquired July 8, 2003.

Water quality was characterized and compared to primary and secondary drinking-water standards using data from 3 wells and 5 springs sampled from January 2002 to June 2003 and from other water chemistry data collected during previous studies. Constituents analyzed included major ions, trace elements, nutrients, dissolved solids, and isotopes of oxygen and hydrogen. The geochemistry of ground water and streams is described using these analyses.

\section{Acknowledgments}

The authors express appreciation to Norman Knox who granted access to property and provided supplies, materials, and equipment for this study; also to John Lenz, and Russel Mendoza who granted access to their property and provided historical information about Dry Valley. The authors also acknowledge the following agencies for assistance in this study; Washoe County Department of Water Resources, California Department of Water Resources, and Lassen County Department of Community Development. 


\section{Geographic Setting}

Dry Valley is a slightly rectangular east-west trending basin in west-central Nevada, about 25 miles north of the Reno-Sparks area (fig. 1). The boundary of the hydrographic area, which generally coincides with the drainage-area boundary, encompasses about $82 \mathrm{mi}^{2}$ in Washoe County, Nev., and about $3 \mathrm{mi}^{2}$ in Lassen County, Calif.

Currently, the population in Dry Valley consists of one part-time resident in the southwest part of the valley. The principle industry in the area is open-range cattle grazing, which is supported by small areas of natural meadow grass and rangeland vegetation. Near the central part of the valley floor along Dry Valley Creek, a small commercial gravel pit is operated infrequently (fig. 2).

Dry Valley is topographically open to the west and is bounded on the north, east, and south by fault-controlled mountain blocks. Although a small area of Dry Valley extends into California, the Nevada-California State line was chosen as the western boundary of the study area to provide a practical location for estimating ground-water outflow (fig. 2). Dry Valley Creek, which drains Dry Valley, flows across the western boundary and is tributary to Long Valley Creek in California. Honey Lake, which is about 20 miles northwest of Dry Valley, is the terminal lake for Long Valley Creek (fig. 1). The altitude of the valley floor ranges from $4,430 \mathrm{ft}$ above sea level, where Dry Valley Creek crosses the State line, to nearly 4,600 ft about three miles east.

The northern boundary of the study area is made up of the northwest-trending Fort Sage Mountains. State Line Peak, the highest peak in the range, reaches 7,990 ft. A small topographically closed subbasin (about $9 \mathrm{mi}^{2}$ ) referred to by Rush (1968, p. 18) as the Newcomb Lake Hydrographic Area completes the northern boundary (fig. 1). The Virginia Mountains, with altitudes approaching $8,200 \mathrm{ft}$, make up the entire eastern boundary and separates Dry Valley from Pyramid Lake, another terminal lake. Seven Lakes Mountain (about 6,000 ft) and the northern extension of Dogskin Mountain (about 6,600 ft) make up the southern boundary.

\section{Climate and Vegetation}

The principal sources of moisture to west-central Nevada are the Pacific Ocean and Gulf of Mexico. The most important source is the Pacific Ocean, which produces moisture from October to June; the Gulf of Mexico produces most of the moisture from July to mid-September (Houghton, 1969, p. 5; Brenner, 1974). The study area lies in the rain shadow of the Sierra Nevada and, as a result, has an arid to semiarid climate.

No long-term precipitation stations operate within the study area; however, long-term precipitation data are available from two weather stations near Doyle California, one station at Sutcliff, a small community along the western shore of Pyramid Lake, and one at Sand Pass, about 17 miles north of the study area (fig. 1; Western Regional Climate Center, 2003). Average annual precipitation, based on the 30-year record (1971-2000) at Doyle $(4,240 \mathrm{ft})$ is 11.81 inches, for Doyle $4 \operatorname{SSE}(4,390 \mathrm{ft})$ is $17.44 \mathrm{in}$. and for Sutcliff (4,000 ft) is $8.33 \mathrm{in}$. Average annual precipitation determined for Sand Pass $(3,900)$ is 7.81 inches for the previous 30-year record (1961-1990). More than 60 percent of the annual precipitation occurs during the period of November through March. Annual precipitation recorded at both Doyle stations and Sutcliff for several water years prior to the study and during the study (1999 through 2003) was between 15 and 83 percent below the 30-year average of 1971-2000.

Temperatures in the study area vary greatly, as is typical in arid to semiarid climates. Maximum summer temperatures can reach $100^{\circ} \mathrm{F}$ but normally range from 80 to $90^{\circ} \mathrm{F}$. Minimum temperatures in the winter often can fall below $0^{\circ} \mathrm{F}$, but range from about 22 to $30^{\circ} \mathrm{F}$. The average annual growing season is about 140 days (Rush and Glancy, 1967, p. 7).

The pattern of natural vegetation in Dry Valley reflects the general long-term distribution of precipitation, the physical and chemical properties of the soil, and depth to ground water. The sagebrush community is the principal vegetation in Dry Valley and covers much of the alluvial slopes adjacent to the valley floor. Mixed woodlands of pinyon and juniper sparsely cover the surrounding mountains and isolated juniper trees are scattered across the valley floor. Vegetation on the valley floor, where the water table is shallow, consists mostly of saltgrass with small isolated stands of greasewood, rabbitbrush, and big sagebrush. Vegetation growing in areas where the water table or capillary fringe above the water table is shallow and within reach of their root system are called phreatophytes (Meinzer, 1927, p. 1). Phreatophytic vegetation has a limited areal extent in Dry Valley. Based on field mapping and satellite imagery acquired on July 8, 2003, phreatophytic vegetation on the valley floor covers about 620 acres. Riparian type vegetation found along stream channels and near springs and ground-water seeps includes cottonwood trees, willows, and a variety of shrubs and grasses.

\section{Geologic Setting}

The study area lies on the very western edge of the Great Basin region of the Basin and Range physiographic province. The Great Basin region is characterized by internal drainage and the Basin and Range province is characterized by generally north-south trending mountain ranges separated by valleys. Extensional faulting that began about 17 million years ago (Ma; Stewart, 1980, p. 110) produced the present day physiography. This faulting was caused by extension of the earth's crust that uplifted the mountain blocks and down dropped the valley floors. Erosion of materials from the mountain blocks has partly filled the valleys with unconsolidated sediments which form the principal aquifers in the Great Basin. 


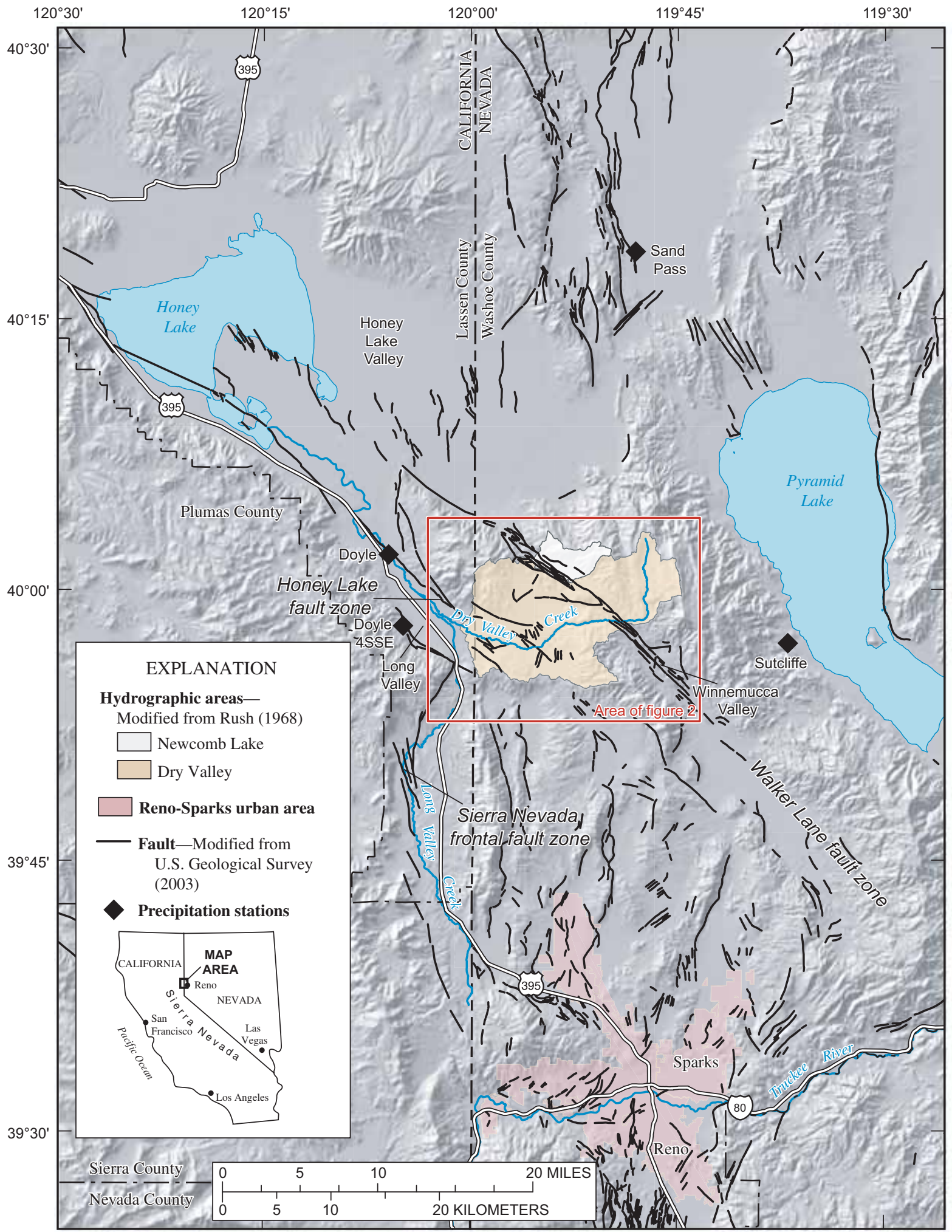

Base from U.S. Geological Survey digital data, 1:100,000, 1979-1982.

Universal Transverse Mercator projection, North American Datum of 1927.

Shaded-relief base from 30-meter Digital Elevation Model; sun illumination from

northwest at 30 degrees above horizon.

Figure 1. General location of Dry Valley, west-central Nevada. 


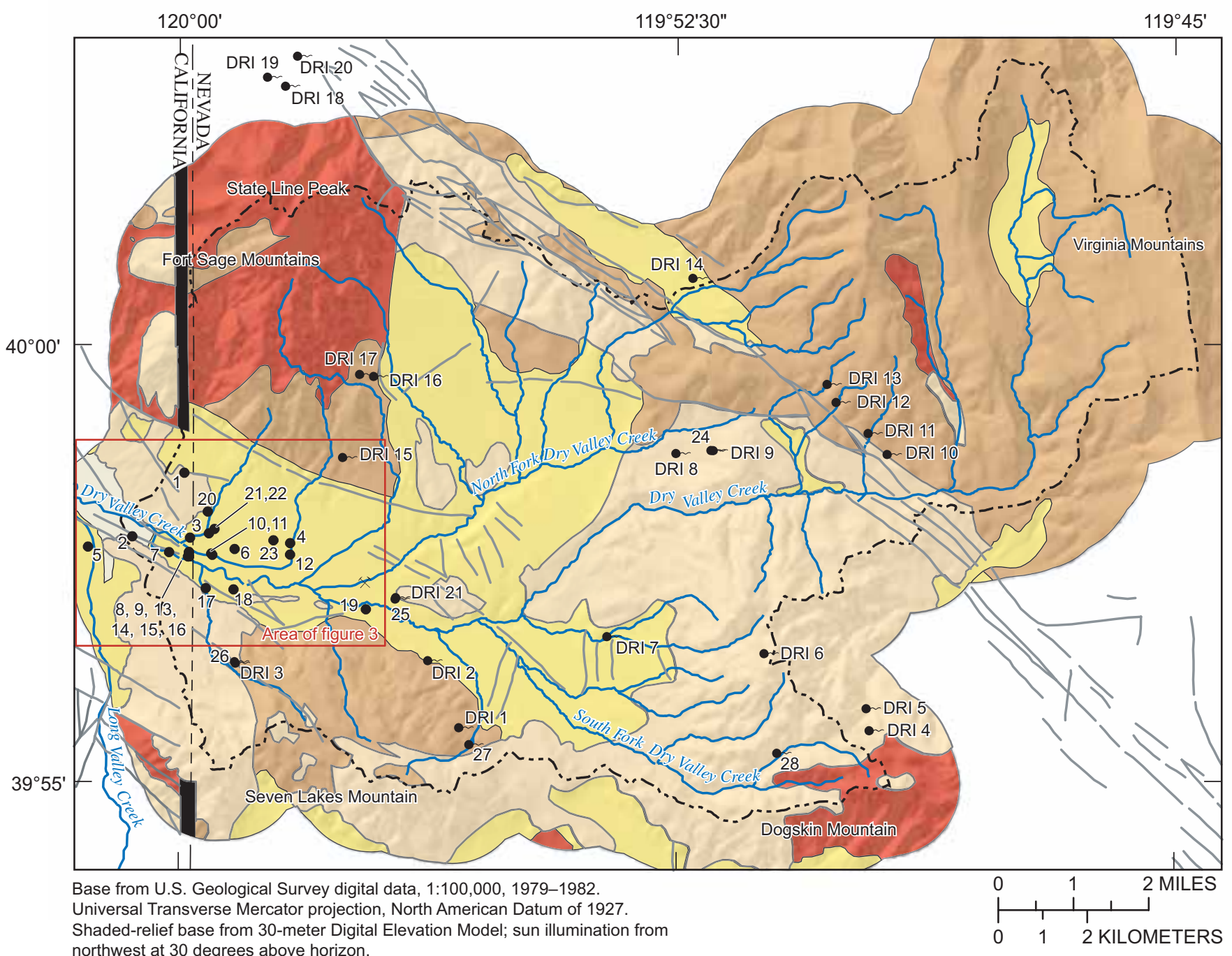

\section{EXPLANATION}

Basin-fill sediments (Quaternary)_Unconsolidated to poorly consolidated interbedded clay, silt, sand, gravel, and boulders

Lake deposits (Quaternary) — Semi-consolidated sand, silt, clay, and minor fine gravel of Lake Lahontan (Grose and Mergner, 2000)

Volcanic rocks (Tertiary) — Basalt, basaltic andesite, andesite flows, and flow breccias of Pyramid Sequence (Bonham, 1969, p. 28)

Rhyolitic tuffs or Tuffaceous deposits (Tertiary) — Welded and unwelded ash-fall and ash-flow tuffs, and tuffaceous sedimentary deposits (Bonham, 1969, p. 23; Grose and Mergner, 2000)

Granitic rocks (pre-Tertiary)_Undifferentiated plutonic rocks, principally biotite-hornblende granodiorite in composition (Bonham, 1969, p. 8)

Area of unmapped geology

- - - - Boundary of hydrographic area-Modified from Rush (1968)

Fault-Modified from U.S. Geological Survey (2003)

19 Well sites-Number corresponds to table 1

26 Spring sites-Number corresponds to table 1 (DRI indicates spring data from Thomas and Albright, 2003)

父 Gravel pit

Figure 2. Geographic features of study area, distribution of geologic units and faults, and locations of wells and springs used in this study. 


\section{Estimates of Natural Ground-Water Discharge and Characterization of Water Quality in Dry Valley, 2002-2003}

\section{Structural History}

Dry Valley HA is near the intersection of two major zones of faulting. One is northwest-trending strike-slip movement along the Walker Lane fault zone and the other is north-south trending normal faulting of the Sierra Nevada frontal fault zone (fig. 1; Bell, 1984, p. 35; Bonham, 1969, p. 52, Grose and Merger, 2000). Strike-slip faults typically have horizontal movement, whereas normal faults have vertical movement. The Walker Lane fault zone is a broad zone of faulting that extends from Las Vegas, Nev. to Honey Lake Valley, Calif. (fig. 1; Bonham, 1969, p. 43-45). Although large vertical displacements along the Walker Lane fault zone have been noted, the dominant sense of displacement has been right-lateral, strikeslip, with as much as $20 \mathrm{mi}$ of displacement (Bonham, 1969, p. 45). The Sierra Nevada frontal fault zone extends from just west of the valleys north of Reno, southward to Carson Valley, south of Carson City, Nev. (Bell, 1984, p. 32, Grose and Mergner, 2000). Vertical offsets along the Sierra Nevada frontal fault zone are as great as 5,000 ft (Bonham, 1969, p. 50).

Just southwest of Dry Valley HA, northeast to north-south trending faults are abruptly truncated by the right-lateral northwest trending Honey Lake fault zone which is part of the Walker Lane fault zone, as mapped by Grose and Mergner (2000). Movement along the Honey Lake fault zone is active as shown by displacement in the Holocene Epoch, less than 10 thousand years ago $(\mathrm{Ka})$, and may have formed the sedimentary basin beneath the lower part of Long Valley Creek (Grose and Mergner, 2000). Northwest trending strike-slip faults are mapped near where Dry Valley Creek crosses the State line and continues along a zone through the center of valley (fig. 1). Movement along these faults also is vertical, producing the uplift of Dogskin Mountain (Bonham, 1969, p. 52).

In consolidated rocks, faults may be barriers to, or conduits for ground-water flow (Goodwin and others, 1999, p. 1-2; Caine and Forster, 1999, p. 124; Antonellini and others, 1999, p. 24; Nelson and others, 1999 , p. 69). In unconsolidated sediments, faults usually are barriers to ground-water flow (Goodwin and others, 1999, p. 27; Heynekamp and others, 1999, p. 27).

\section{Geologic Units}

Geologic units in Dry Valley HA have been mapped most recently by Grose and Mergner (2000) in California, and by Bonham (1969) in Nevada. The mapping in California is at a scale of 1:62,500, whereas the mapping in Nevada is at a scale of 1:250,000. Neither of the two maps cover an area about 1,000 $\mathrm{ft}$ wide along the State line. Resolution of discrepancies between the two geologic maps and extrapolation across the $1,000 \mathrm{ft}$ wide data gap required reconnaissance mapping by the authors. This was accomplished by collecting samples, locating geologic contacts with a Global Positioning System, and using aerial photography. The reconnaissance mapping was done along the State line about $1.5 \mathrm{mi}$ north and about $3 \mathrm{mi}$ south from Dry Valley Creek (fig. 2). The reconnaissance mapping involved extending the contact of the rhyolitic tuff of Grose and Merger (2000) eastward into Nevada. The rhyolitic tuff unit as mapped by the authors in Nevada appear largely non-welded and also may include tuffaceous-sedimentary deposits. Discrepancies in geologic mapping within the mountain blocks north and south of this area were not resolved. Geologic units beyond the area of reconnaissance mapping are shown on figure 2 as originally mapped by Grose and Mergner (2000) and Bonham (1969).

The mountain blocks surrounding Dry Valley HA are composed of granitic rocks of pre-Cenozoic age (more than $66 \mathrm{Ma})$, overlain by two volcanic-rock units of Tertiary age (1.6 to 66 Ma; Bonham, 1969, p. 52). Near Dry Valley HA the granitic rocks are exposed near the center of Fort Sage Mountains, on the southern part of Dogskin Mountain (Bonham, 1969, p. 52, plate 1), and on the western flank of Seven Lakes Mountain (Grose and Mergner, 2000). The granitic rocks likely are thousands of feet thick and form an impermeable basement to ground-water flow.

The oldest volcanic rocks directly overlying the granitic rocks are rhyolitic tuffs of early to middle Miocene age, about 23 to $28 \mathrm{Ma}$ (Bonham, 1969, p. 25; Grose and Mergner, 2000). The ash-fall and ash-flow tuffs range from welded to nonwelded and are mapped as the Hartford Hill Rhyolite by Bonham (1969, p. 23). Both Bonham (1969, p. 23) and Grose and Mergner (2000) describe interbedded sandstone and conglomerate near the base of the tuffs. As mapped by Grose and Mergner (2000) in Calif., the tuffs form low hills on the northern and southern sides of the western part of Dry Valley HA (fig. 2). In Nevada, the tuffs are exposed on the flanks of the Fort Sage and Seven Lakes Mountains, and on the northern end of Dogskin Mountain (fig. 2; Bonham 1969, plate 1). Bonham (1969, p. 23) states the maximum thickness for the tuffs to be about 4,000 ft near Dogskin Mountain. Grose and Mergner (2000) estimate the tuffs may reach great thicknesses and extend into the subsurface beneath Long Valley. Based on exposures near the western part of Dry Valley HA, non-welded tuffs and tuffaceous sediments may underlie much of the valley floor in that area. Where welded and fractured, the tuffs and tuffaceous sediments may be capable of transmitting ground water. In contrast, non-welded tuffs likely are fairly impermeable to ground-water flow.

Overlying the rhyolitic tuffs are rocks informally assigned to the Pyramid Sequence by Bonham (1969, p. 28). The Pyramid Sequence consists of a complex mixture of basalt, basaltic andesite, andesite flows, and flow breccias. These rocks are interbedded with sedimentary rocks of diatomite and shale, rhyolitic tuffs and tuff breccias, and dacite welded tuffs (Bonham, 1969, p. 28). The Pyramid Sequence is late Miocene in age, ranging from 5 to $15 \mathrm{Ma}$ (Bonham, 1969, p. 30). The Pyramid Sequence covers large areas of the Virginia Mountains and is exposed on the southern and northern flanks of the Fort Sage and Seven Lakes Mountains, respectively (fig. 2). Bonham (1969, p. 28 and 29) states the thickness of the unit may range from 2,000 to 3,000 ft. Basaltic rocks of the Pyramid 
Sequence form an important aquifer in the southeastern corner of Honey Lake Valley with a horizontal hydraulic conductivity of greater than $100 \mathrm{ft} / \mathrm{d}$ where fractured (Handman and others, 1990, p. 14 and 15).

Henry and others (2002) have completed a preliminary geologic map at a scale of 1:24,000 covering the southeastern corner of Dry Valley HA. They map the Pyramid Sequence in more detail than provided by the map of Bonham (1969), and map Tertiary tuffaceous rocks of Oligocene age (24-38 Ma). In addition, they provide a geologic cross section approximately parallel to the topographic divide between Dry Valley HA and Winnemucca Valley. Rocks shown to underlie the divide include sandstone, conglomerate, and breccia of the Pyramid Sequence, and tuffaceous rocks of Oligocene age. Descriptions of the degree of welding of the tuffaceous rocks are not provided. Basaltic and andesitic lavas of the Pyramid Sequence, along with the zone of faulting between Dry Valley HA and Winnemucca Valley, are mapped southeast of the geologic section.

Unconsolidated sediments beneath and along the margins of the floor of Dry Valley HA overlie the consolidated rocks previously described (figs. 2 and 3). In Nevada, Bonham (1969, plate 1) describes the unconsolidated sediments near the center of Dry Valley as stream and alluvial-fan deposits of Quaternary age, less than 1.6 Ma. In California, adjacent to Dry Valley Creek, Grose and Merger (2000) mapped Quaternary alluvium to extend about $0.5 \mathrm{mi}$ west of the State line. West of this point they describe the Quaternary sediments bounding Dry Valley Creek as semi-consolidated lake deposits of sand and silt derived from Lake Lahontan.

Pluvial Lake Lahontan filled many western Nevada basins during the late Pleistocene, reaching high stands of about 4,364 $\mathrm{ft}$ above sea level from about 130 to $180 \mathrm{Ka}$, and again from 12.5 to $13.5 \mathrm{Ka}$ (Benson and Thompson, 1987, p. 78; Reheis and others, 2002, p. 54). This high-stand altitude was reached about $1.2 \mathrm{mi}$ west of the State line near the mouth of the valley. More recently, Reheis and others (2002) have presented evidence that high stands of Lake Lahontan reached 4,593 ft above sea level in the middle Pleistocene, about $650 \mathrm{Ka}$. This altitude is reached about $2.7 \mathrm{mi}$ east of the State line, extending into Dry Valley. The presence of Lake Lahontan in the lower reaches of Dry Valley produced poorly sorted sediments near its mouth. As the levels of Lake Lahontan rose and fell, deposition near the western part of Dry Valley alternated between finegrained silt and clay during high stands, and coarse-grained beach and stream deposits during low stands.

Lithologic descriptions of drill cuttings from boreholes installed for this study note rounded cobbles, gravel, and sand intermixed with silt and clay throughout the upper $200 \mathrm{ft}$ of unconsolidated sediments along the State line. Cobbles were noted to depths of $80 \mathrm{ft}$, and gravel to depths of $440 \mathrm{ft}$. Increasing amounts of clay were noted below depths of $200 \mathrm{ft}$. Near a depth of about $650 \mathrm{ft}$, drill rates decreased markedly in very stiff clays. These clays could be saturated, tuffaceous deposits similar to those exposed north and south of the mouth of Dry Valley.
Geophysical logs collected from the boreholes show the vertical distribution of interbedded coarse- and fine-grained sediments near the State line. Figure 4 shows an example of typical borehole geophysical and lithological logs collected for this study (borehole with well sites 14, 15, and 16). In general, caliper logs show the average diameter and rugosity of the drilled borehole. Natural-gamma logs show clay as relatively high activity values (counts per second) caused by naturally occurring radioactive clay particles. On resistivity logs, coarsegrained sand and gravel are indicated by high resistivity values (ohm-meters), whereas fine-grained silt and clay are indicated by relatively low resistivity values. The logs on figure 4 show sand and gravel layers alternating with clay through the upper 200 to $250 \mathrm{ft}$ of the borehole. Below that depth, sediments become progressively more clayey as indicated by a general decrease in resistivity and increase in gamma activity. However, a sand and gravel layer about $20 \mathrm{ft}$ thick is indicated near $400 \mathrm{ft}$ (fig. 4), along with relatively thin stringers of sand near 490 and $510 \mathrm{ft}$. Below this depth to $778 \mathrm{ft}$, sediments are mostly clay. An increase in clay decreases the effective porosity and permeability of the sediments (Keys, 1990, p. 20).

Seismic-refraction data were collected near the mouth of Dry Valley, about 1,500 ft east of the State line, in order to determine the vertical extent of unconsolidated sediments (fig. $3)$. The seismic-refraction data initially were interpreted in the field from time-distance curves using the intercept-time formula (Dobrin, 1976, p. 297). Subsequent interpretations were guided by an inversion algorithm that uses the delay-time method (Barthelmes, 1946; Pakiser and Black, 1957) to obtain a first-approximation depth model, then enhanced by a series of ray-tracing iterations (Scott, 1993). The resultant velocitydepth profile (fig. 5) shows seismic velocities of 2,500 to $6,600 \mathrm{ft} / \mathrm{s}$, which are typical velocities for unsaturated and saturated unconsolidated sediments, extending to a depth of about $200 \mathrm{ft}$ below land surface. Beneath $200 \mathrm{ft}$, seismic velocities are about $8,000 \mathrm{ft} / \mathrm{s}$, more typical of saturated semiconsolidated sediments which could be representative of saturated non-welded tuffs or tuffaceous deposits (Healy and Press, 1964, p. 347; Zohdy and others, 1974, p. 81; Berger and others, 2001, p. 8). Minimum depths to the underlying granitic basement were computed assuming that the latest recorded traveltime was refracted from an interface with a velocity of 12,000 to $17,000 \mathrm{ft} / \mathrm{s}$, as representing basement velocities. Based on minimum-depth computations, the thickness of semi-consolidated sediments with a velocity of about $8,000 \mathrm{ft} / \mathrm{s}$ is estimated to be at least 800 to $1,000 \mathrm{ft}$ beneath the western side of Dry Valley.

The seismic-velocity change near $200 \mathrm{ft}$, approximately corresponds to the depth where sediments become predominantly clay as determined from the drill cuttings and borehole geophysical logs collected about $1,500 \mathrm{ft}$ west of the seismic profile. This depth may correspond to the top of saturated, nonwelded tuffs or tuffaceous deposits beneath unconsolidated sediments along the State line. The increase in drill rates near a depth of $650 \mathrm{ft}$ may have been caused by a slightly more consolidated section of the tuffaceous deposits. Alternatively, the 


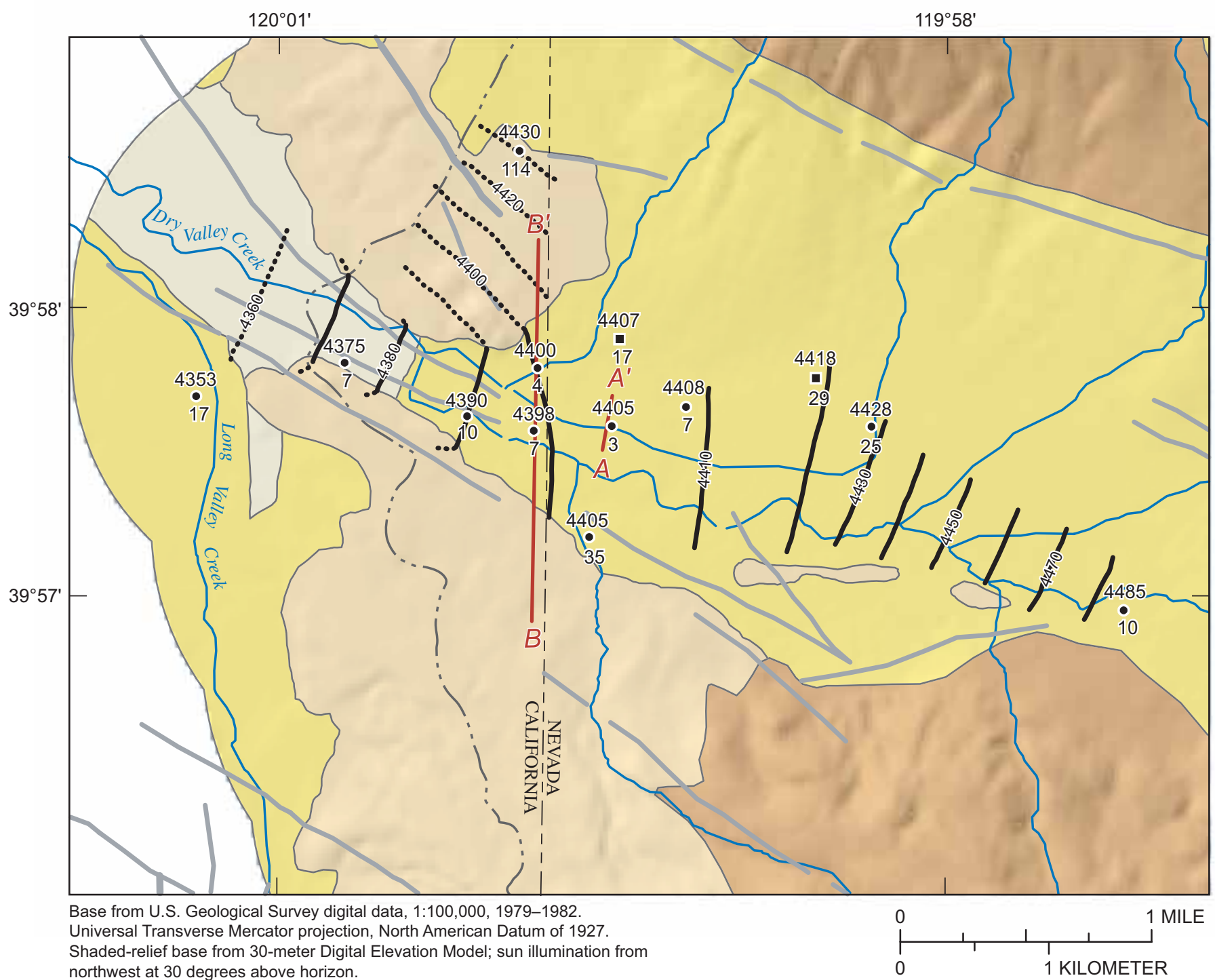

northwest at 30 degrees above horizon.

\section{EXPLANATION}

Basin-fill sediments (Quaternary)_Unconsolidated to poorly consolidated interbedded clay, silt, sand, gravel, and boulders

Lake deposits (Quaternary)—Semi-consolidated sand, silt, clay, and minor fine gravel of Lake Lahontan (Grose and Mergner, 2000)

Volcanic rocks (Tertiary) —Basalt, basaltic andesite, andesite flows, and flow breccias of Pyramid Sequence (Bonham, 1969, p. 28)

Rhyolitic tuffs or Tuffaceous deposits (Tertiary) - Welded and unwelded ash-fall and ash-flow tuffs, and tuffaceous sedimentary deposits (Bonham, 1969, p. 23; Grose and Mergner, 2000)

- - - Boundary of hydrographic area-Modified from Rush (1968)

Fault-Modified from U.S. Geological Survey (2003)

Locations of seismic-refraction profile (A) and hydrogeologic cross section (B)_See figures 5 and 7

Water-level contour, January 2004 - Shows altitude of water level in well screened in Quaternary sediments. Contour interval is 10 feet; dashed where approximately located. Datum is sea level.

4428 Well sites-Location of well used as control point.

25 Upper number is water-level altitude in feet above sea level and bottom number is depth to water in feet.

4418 Hand-dug well sites_-Location of hand-dug well used as control point.

29 Upper number is water-level altitude in feet above sea level and bottom number is depth to water in feet.

Figure 3. Distribution of geologic units and faults in western part of study area. $A-A^{\prime}$, locations of seismic-refraction profile; and $B-B^{\prime}$, hydrogeologic cross section, and contours of ground-water levels and measured depth to ground water in unconsolidated Quaternary sediments, January 2004. 


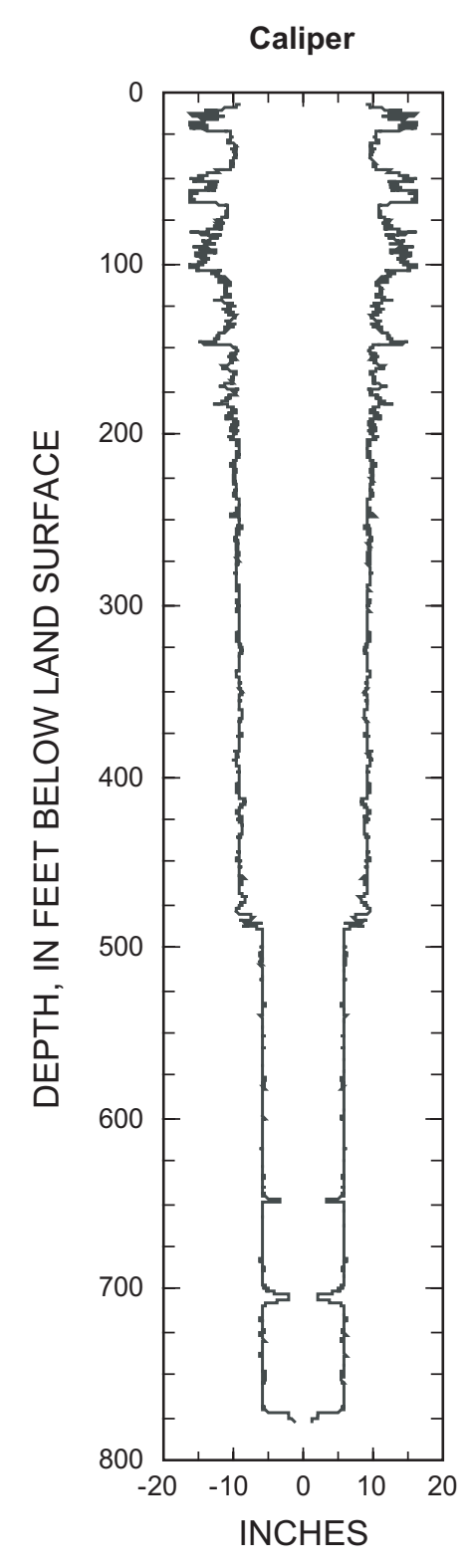

Natural gamma

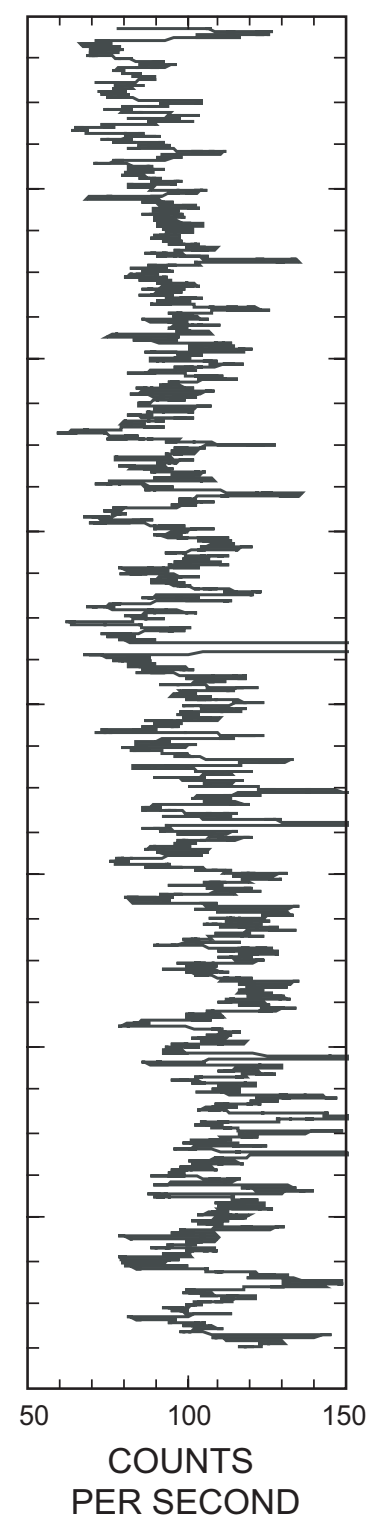

Resistivity

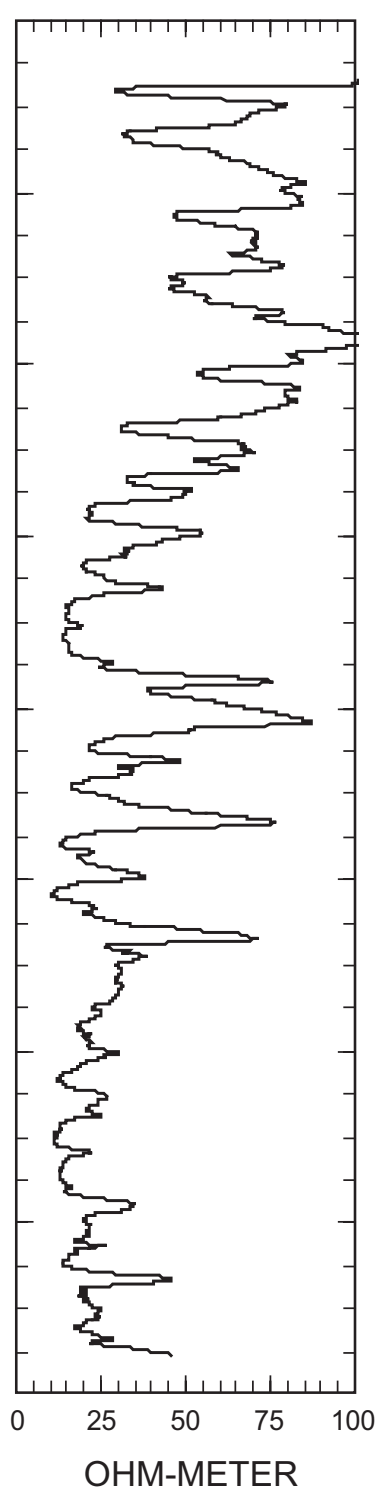

Penetration

rate

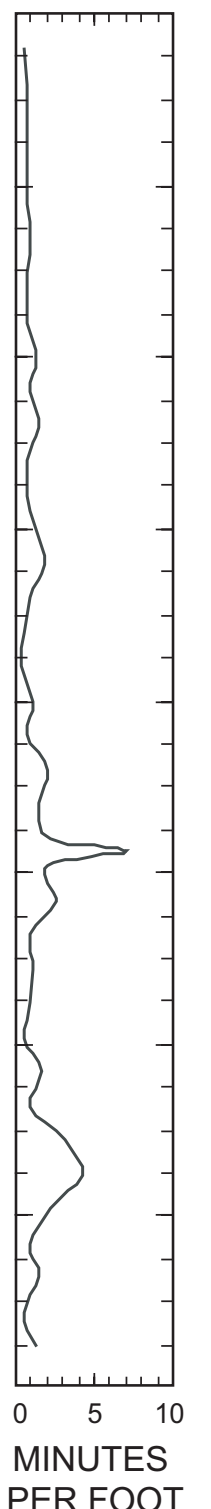

\section{Lithology}

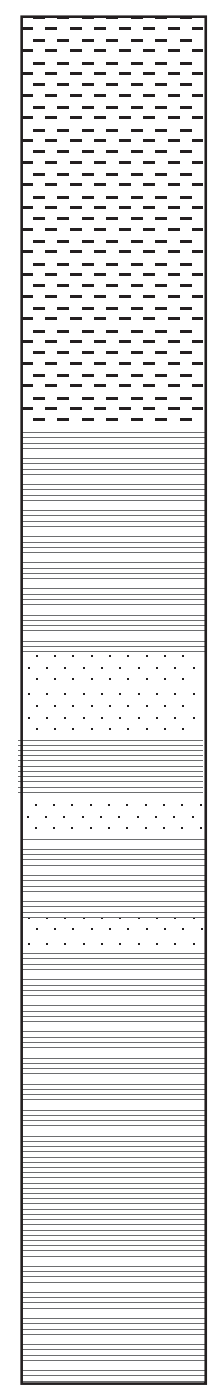
Alternating layers of sand, gravel, silt, and clay

Clay interbedded with silt, sand, and some gravel

\section{Sand and gravel}

Figure 4. Example of borehole-geophysical and lithological logs collected from a borehole where well sites 14, 15, and 16 are installed along the State line, Dry Valley, west-central Nevada. 

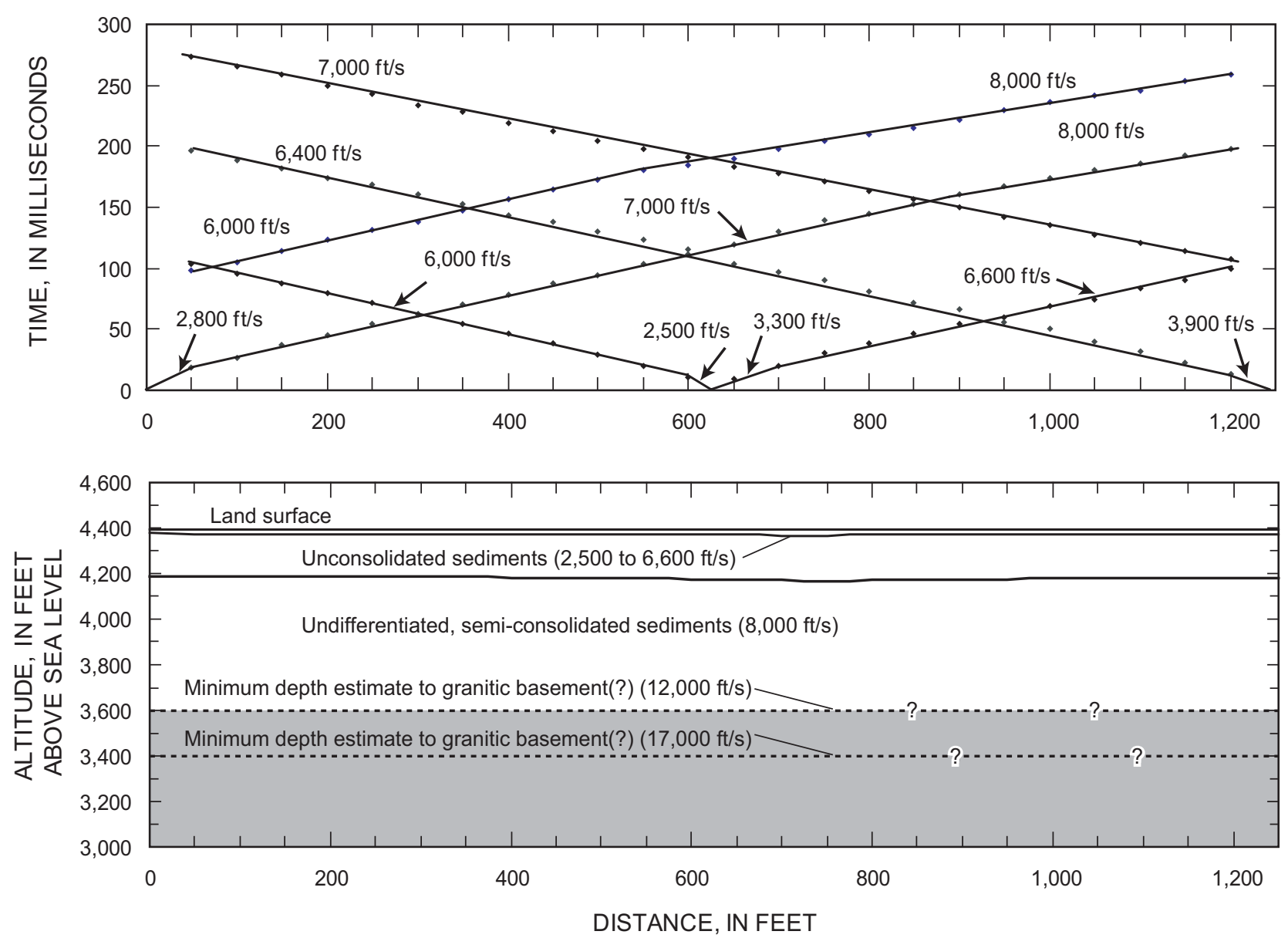

Figure 5. Time-distance curves and resultant velocity-depth cross section for seismic-refraction profile $A-A^{\prime}$, Dry Valley, westcentral Nevada.

upper surface of the tuffaceous deposits may slope towards the west with their top near a depth of $650 \mathrm{ft}$ near the borehole. The sand and gravel layers encountered at depths of 400 to $510 \mathrm{ft}$ could be interbedded sandstone and conglomerate within the tuffaceous deposits noted by Bonham (1969, p. 23) and Grose and Mergner (2000). Regardless of the relative age and original lithology of the sediments, aquifer materials are poorly sorted, have low permeability, and largely are fine-grained below depths of 200 to $250 \mathrm{ft}$. The sediments become more dense below depths of $200 \mathrm{ft}$, about $1,500 \mathrm{ft}$ east of the State line, and below depths of $650 \mathrm{ft}$ along the State line.

\section{Hydrologic Setting}

\section{Surface Water}

The entire drainage area (about $82 \mathrm{mi}^{2}$ ) of Dry Valley is tributary to Dry Valley Creek whose confluence with Long Valley Creek is about 4 mi northwest of the State line in Long Valley, Calif. (fig. 1). Most streams in Dry Valley are ephemeral, although some streams in their upper reaches may be perennial. The generally rectangular pattern of the drainage system in Dry Valley, particularly in the upper reaches, indicates that stream development is structurally controlled (fig. 2; Ritter, 1982, p. 170-171).
Streamflow in Dry Valley Creek was ephemeral between July 2002 and September 2004. Streamflow observations and miscellaneous discharge measurements collected from Dry Valley Creek, about $1 \mathrm{mi}$ west of the State line, indicate streamflow began near the end of October 2002 and had ceased by early May 2003. During this period, average streamflow was less than $0.5 \mathrm{ft}^{3} / \mathrm{s}$. Assuming an average discharge of $0.5 \mathrm{ft}^{3} / \mathrm{s}$ was sustained for 7 months, a maximum of about 210 acre-ft of surface-water outflow from Dry Valley occurred in the 2003 water year (October 2002 through September 2003). Precipitation in the region during the 2003 water year was about 78 percent of the long-term average, which may account for the low streamflow from Dry Valley. Using channel-geometry methods, Rush and Glancy (1967, p. 30) suggest that the long-term average annual streamflow exiting Dry Valley at the State line is $4,000 \mathrm{acre}-\mathrm{ft} / \mathrm{yr}$.

Numerous springs and seeps occur mostly in the mountain blocks surrounding Dry Valley; however, the spring near the center of the valley (site 25; fig. 2) discharges from the basin fill. The proximity of a north-west trending fault just north of the site, indicates that spring discharge probably is fault controlled. During this study, most springs discharged less than $2 \mathrm{gal} / \mathrm{min}$., were stagnant, or were dry. In 2003, several springs that were dry or stagnate in March began discharging in June or July, because of precipitation in April. 


\section{Source and Movement of Ground Water}

All ground water in the study area originates as precipitation. Some precipitation infiltrates to recharge the ground-water system and some runs off as streamflow; however, most is lost to evaporation. The springs in the surrounding mountain blocks discharge ground water that is either lost to evaporation or infiltrates back into the subsurface down gradient of the spring. In Dry Valley, ground water moves along paths of least resistance, from areas of high hydraulic head in the mountain blocks, to areas of low hydraulic head in sediments beneath the valley floor. On the valley floor, much of the ground water is consumed by phreatophytic vegetation or lost directly through bare-soil evaporation. The remainder of the ground water flows westward towards Long Valley.

Early in the study the need for additional wells near the mouth of Dry Valley was recognized. Eight wells were installed in 5 boreholes that penetrated unconsolidated sediments near the mouth of Dry Valley to provide data on ground-water levels, lithology, aquifer properties, and water quality. Sites 10 and 11 were installed in September 2002 at shallow depths using a hollow-stem auger. The remaining wells were installed in November 2002 using mud-rotary methods to depths of 140 to $547 \mathrm{ft}$ (table 1). All wells were cased with polyvinyl-chloride casing with 10 to $40 \mathrm{ft}$ of well screen having 0.02 inch slots. At two boreholes, the wells are 2-in. diameter nested piezometers, screened at different depths within the same borehole. At sites 8 and 9 , the wells were installed to depths of 150 and $385 \mathrm{ft}$, respectively. At sites 14, 15, and 16, the wells were installed to depths of 40, 250, and $547 \mathrm{ft}$, respectively. For the nested piezometers, bentonite grout was emplaced below,

between, and above each well screen and 0.25 -in. silica gravel was emplaced around the well screen. One well (site 3; fig. 2), was constructed with 6-in. diameter casing and well screen to allow installation of a 4-in. submersible pump. All wells were developed by air-lifting and surging.

Existing wells in the study area consist of irrigation wells, domestic and stock wells, monitoring wells installed for a previous study, and several shallow hand-dug wells. Most of these wells and those installed for this study were surveyed to a common datum in November 2002.

Water levels in wells near the floor of Dry Valley indicate ground-water flow is westward, toward Long Valley (fig. 3; app. 1). Water-level contours in figure 3 were developed using water-level data only from wells screened in the upper $100 \mathrm{ft}$ of unconsolidated sediments. The water-table gradient increases from $0.003 \mathrm{ft} / \mathrm{ft}$ east of the State line to $0.005 \mathrm{ft} / \mathrm{ft}$ west of the State line. The increase in gradient may be caused by the combination of less permeable lake deposits to the west and a restriction of ground-water flow through the narrow width of unconsolidated sediments west of the State line (fig. 3). In addition, the non-welded rhyolitic tuffs exposed on the northern and southern sides of the unconsolidated sediments have a low permeability and may produce a damming effect on ground water upgradient (east) from the State line. The water level in site 1, on the northern side of Dry Valley, indicates a steep gradient, about $0.13 \mathrm{ft} / \mathrm{ft}$, through rhyolitic tuff southwestward toward
Dry Valley Creek (fig. 3). The steep gradient indicates that the tuffs have a low permeability and likely transmit little ground water.

Depth to water is less than $10 \mathrm{ft}$ below land surface in wells near the floor of Dry Valley, and increases to $30 \mathrm{ft}$ or more in sites 17 and 4 near the toe of the alluvial fans on the southern and northern sides of the valley floor (figs. 2 and 3; app. 1). Depth to water at site 1 , near the upper contact of the rhyolitic tuffs is more than $100 \mathrm{ft}$.

In the nested piezometers, water levels decrease with depth, indicating the potential for downward flow (app. 1). Dividing the difference in water levels by the distance between the mid-point of the screened intervals, vertical hydraulic gradients measured in sites 14-16 average about $0.02 \mathrm{ft} / \mathrm{ft}$. Similarly for sites 8 and 9 , the vertical hydraulic gradient is about 0.014 $\mathrm{ft} / \mathrm{ft}$. Although the water levels indicate a potential downward gradient, the presence of interbedded clays indicate a low vertical hydraulic conductivity The low vertical hydraulic conductivity of the clays would impede downward ground-water flow at those locations near the State line.

Water levels measured during the study show seasonal fluctuations are small, less than $3 \mathrm{ft}$ from 2002 through 2003 (fig. 6). Site 19 shows the greatest fluctuation, likely because it is near the South Fork of Dry Valley Creek and in an area of phreatophytic vegetation (fig. 2). Conversely, sites 4 and 12 shows fluctuations of less than $1 \mathrm{ft}$, probably due to the greater distance from Dry Valley Creek and not being in an area of phreatophytes. Sites 3 and 11, near the center of the valley floor, show fluctuations of about 1.5 to $2 \mathrm{ft}$. Water levels at sites showing the greatest seasonal fluctuations were highest in Spring of 2003 after recharge from winter precipitation, and lowest in late summer and fall of 2003 as ground water was discharged by phreatophytic vegetation and bare-soil evaporation near the valley floor.

The location of northwest-trending faults indicates there may be potential for ground-water outflow through faulted and fractured basaltic rocks along the southeastern part of upper Dry Valley to adjacent Winnemucca Valley (fig. 1). Numerous springs on the northwestern end of Winnemucca Valley also indicate the potential for subsurface flow across the study-area boundary. The lack of wells for measurement of water levels on either side of the hydrographic-area boundary makes determination of this possibility difficult. However, the altitude of areas of phreatophytes in upper Dry Valley and Winnemucca Valley are similar, about 5,250 ft. Assuming the depth to water is similar beneath both areas of phreatophytes, there is not a significant water-table gradient between upper Dry Valley and Winnemucca Valley. This indicates that no significant groundwater outflow southeastward from upper Dry Valley takes place.

Similarly, there is potential for subsurface outflow through faulted and fractured basaltic rocks along northwest-trending faults towards Honey Lake Valley, where the valley floor lies at an altitude of about 4,100 ft. The northwest-trending faults intersect the floor of Honey Lake Valley near the CaliforniaNevada State line where there are no springs or detectable areas of seepage. This fact indicates the lack of subsurface outflow from Dry Valley northwestward towards Honey Lake Valley. 
Table 1. Site number, location, well construction, and type of data available for well and spring sites, Dry Valley, west-central Nevada

[Abbreviations: --, no data; NA, not applicable. Available data: AT, aquifer test; DL, drillers' log; GL, geophysical logs; QW, water chemistry; WL, ground-water levels.]

\begin{tabular}{|c|c|c|c|c|c|c|c|c|c|}
\hline \multirow[b]{2}{*}{$\begin{array}{c}\text { Site } \\
\text { number } \\
\text { (fig. 2) }\end{array}$} & \multicolumn{2}{|c|}{ U.S. Geological Survey site designations ${ }^{a}$} & \multirow[b]{2}{*}{$\begin{array}{c}\text { Latitude } \\
\text { (degrees, } \\
\text { minutes, } \\
\text { seconds) }\end{array}$} & \multirow[b]{2}{*}{$\begin{array}{l}\text { Longitude } \\
\text { (degrees, } \\
\text { minutes, } \\
\text { seconds) }\end{array}$} & \multirow{2}{*}{$\begin{array}{l}\text { Land } \\
\text { surface } \\
\text { altitude } \\
\text { (feet } \\
\text { above } \\
\text { mean } \\
\text { sea } \\
\text { level) }\end{array}$} & \multicolumn{3}{|c|}{ Well construction } & \multirow[b]{2}{*}{ Available data } \\
\hline & Local identification & $\begin{array}{c}\text { Standard } \\
\text { identification }\end{array}$ & & & & $\begin{array}{l}\text { Casing/well } \\
\text { depth (feet) }\end{array}$ & $\begin{array}{l}\text { Casing/well } \\
\text { diameter } \\
\text { (inches) }\end{array}$ & $\begin{array}{l}\text { Screened } \\
\text { interval } \\
\text { (feet } \\
\text { belowland } \\
\text { surface) }\end{array}$ & \\
\hline \multicolumn{10}{|c|}{ Well sites } \\
\hline 1 & 024N018E06H001M & 395832119595901 & 395832 & 1195959 & 4544 & 132 & 6 & $120-130$ & WL \\
\hline 2 & 024N018E07D001M & 395748120004601 & 395748 & 1200046 & 4382.3 & 29 & 8 & -- & WL \\
\hline $\mathrm{b}_{3}$ & 95N24 E18 07ADAB1 & 395747119595401 & 395747 & 1195954 & 4403.8 & 140 & 6 & $100-140$ & WL,DL,GL,AT \\
\hline 4 & 95N24 E18 09BCBD1 & 395743119582401 & 395743 & 1195824 & 4465.8 & 350 & 16 & $60-350$ & WL,DL \\
\hline 5 & 024N017E01F001M & 395740120012601 & 395741 & 1200126 & 4370 & -- & 12 & -- & WL \\
\hline 6 & 95N24 E18 08ACCC1 & 395739119591401 & 395739 & 1195914 & 4415.2 & 23 & 2 & -- & WL,DL \\
\hline 7 & 024N018E07G001M & 395737120001301 & 395737 & 1200013 & 4490 & 11 & 10 & -- & WL \\
\hline $\mathrm{b}_{9}$ & 95N24 E18 07DAAB1 & 395737119595501 & 395737 & 1195955 & 4401.9 & 385 & 2 & $375-385$ & WL,DL,GL,QW \\
\hline $\mathrm{b}_{10}$ & 95N24 E18 08CBAA1 & 395736119593501 & 395736 & 1195935 & 4408.7 & 32 & 2 & $22-32$ & WL,DL \\
\hline $\mathrm{b}_{11}$ & 95N24 E1808CBAA2 & 395735119593401 & 395735 & 1195934 & 4408.4 & 32 & 2 & $22-32$ & WL,DL \\
\hline 12 & 95N24 E18 09CABB1 & 395735119582401 & 395735 & 1195824 & 4453.1 & 35 & 2 & $20-35$ & WL,DL \\
\hline 13 & 025N018E07J001M & 395734119595601 & 395734 & 1195956 & 4404.9 & 440 & 16 & $110-440$ & WL,DL,GL,AT \\
\hline $\mathrm{b}_{14}$ & 95N24 E18 07ADCD3 & 395734119595503 & 395734 & 1195955 & 4404.3 & 40 & 2 & $30-40$ & WL,DL,GL,QW \\
\hline $\mathrm{b}_{15}$ & 95N24 E18 07ADCD2 & 395734119595502 & 395734 & 1195955 & 4404.3 & 250 & 2 & $240-250$ & WL,DL,GL \\
\hline $\mathrm{b}_{16}$ & 95N24 E18 07ADCD1 & 395734119595501 & 395734 & 1195955 & 4404.3 & 547 & 2 & $537-547$ & WL,DL,GL \\
\hline 17 & 95N24 E18 08CCDC1 & 395716119593801 & 395712 & 1195940 & 4438.0 & 100 & 9 & $80-100$ & WL,DL \\
\hline 18 & 95N24 E18 08CDDD1 & 395711119591501 & 395711 & 1195915 & 4421 & ${ }^{c_{2}} 20$ & 2 & -- & WL,DL \\
\hline 19 & 95N24 E18 15BBDD1 & 395657119571601 & 365657 & 1195716 & 4495 & 20 & 2 & $10-20$ & WL,DL,QW \\
\hline \multicolumn{10}{|c|}{ Hand-dug wells } \\
\hline 20 & 95N24 E18 05CCCD1 & 395805119593801 & 395805 & 1195938 & 4452 & 41 & NA & NA & WL \\
\hline 21 & 95N24 E18 08BDDD1 & 395753119593201 & 395753 & 1195932 & 4421 & 18 & NA & NA & WL \\
\hline 22 & 95N24 E18 08BCBA1 & 395750119593701 & 395750 & 1195937 & 4420 & 15 & NA & NA & WL \\
\hline 23 & 95N24 E18 08ADAD1 & 395745119583901 & 395745 & 1195839 & 4447 & 39 & NA & NA & WL \\
\hline
\end{tabular}


Table 1. Site number, location, well construction, and type of data available for well and spring sites, Dry Valley, west-central Nevada--Continued

\begin{tabular}{|c|c|c|c|c|c|c|c|c|c|}
\hline \multirow[b]{2}{*}{$\begin{array}{c}\text { Site } \\
\text { number } \\
\text { (fig. 2) }\end{array}$} & \multicolumn{2}{|c|}{ U.S. Geological Survey site designations ${ }^{a}$} & \multirow[b]{2}{*}{$\begin{array}{c}\text { Latitude } \\
\text { (degrees, } \\
\text { minutes, } \\
\text { seconds) }\end{array}$} & \multirow[b]{2}{*}{$\begin{array}{c}\text { Longitude } \\
\text { (degrees, } \\
\text { minutes, } \\
\text { seconds) }\end{array}$} & \multirow{2}{*}{$\begin{array}{l}\text { Land } \\
\text { surface } \\
\text { altitude } \\
\text { (feet } \\
\text { above } \\
\text { mean } \\
\text { sea } \\
\text { level) }\end{array}$} & \multicolumn{3}{|c|}{ Well construction } & \multirow[b]{2}{*}{ Available data } \\
\hline & Local identification & $\begin{array}{c}\text { Standard } \\
\text { identification }\end{array}$ & & & & $\begin{array}{l}\text { Casing/well } \\
\text { depth (feet) }\end{array}$ & $\begin{array}{c}\text { Casing/well } \\
\text { diameter } \\
\text { (inches) }\end{array}$ & $\begin{array}{l}\text { Screened } \\
\text { interval } \\
\text { (feet } \\
\text { belowland } \\
\text { surface) }\end{array}$ & \\
\hline \multicolumn{10}{|c|}{ Spring sites } \\
\hline 24 & 95N24 E19 05AADB1 & 395846119515801 & 395846 & 1195158 & 5290 & NA & NA & NA & QW \\
\hline 25 & 95N24 E18 15ABAC1 & 395704119564501 & 395704 & 1195645 & 4530 & NA & NA & NA & QW \\
\hline 26 & 95N24 E18 17DCCD1 & 395620119590901 & 395620 & 1195909 & 4850 & NA & NA & NA & QW \\
\hline 27 & 95N24 E18 26ABAC1 & 395523119553901 & 395523 & 1195539 & 5090 & NA & NA & NA & QW \\
\hline 28 & 95N24 E19 28DBBB1 & 395516119510201 & 395516 & 1195102 & 5690 & NA & NA & NA & QW \\
\hline
\end{tabular}

${ }^{a}$ Each U.S. Geological Survey data-collection site is assigned a unique identification on the basis of geographic location. Wells and springs are identified by a local system (Nevada and California) and a standard latitude-longitude system. For convenience, short site number (1 - 28) also are used for sites discussed in this report. In California wells are numbered according to their location in the rectangular system for subdivision of public lands. Identification consists of the township number, north or south $(\mathrm{N}$ or $\mathrm{S})$; the range number, east or west $(\mathrm{E}$ or $\mathrm{W})$; and the section number. Each section is divided into sixteen 40-acre tracts lettered consecutively (except I and O) beginning with "A" in the northeast corner of the section and progressing in a sinusoidal manner to "R" in the southeast corner. Within the 40-acre tract, wells are sequentially numbered in the order they are inventoried. The final letter (M) refers to the Mount Diablo base line and meridian. In Nevada, a local site designation is used to identify a site by hydrographic area (Rush, 1968) and by the official rectangular subdivision of the public lands referenced to the Mount Diablo base line and meridian. Each site designation consists of four units. The first unit is the hydrographic area number. The second unit is the township, preceded by $\mathrm{N}$ to indicate location north of the base line. The third unit is the range, preceded by "E" to indicate location east of the meridian. The fourth unit consists of the section number and letters designating the quarter section, quarter-quarter section and so on (A, B, C, and D indicate the northeast, northwest, southwest, and southeast quarter, respectively), followed by a number indicating the sequence in which the site was recorded.

The standard identification is based on the grid system of latitude and longitude. The number consists of 15 digits. The first six digits denote the degrees, minutes, and seconds of latitude; the next seven digits denote the degrees, minutes, and seconds of longitude; and the last two digits (assigned sequentially) identify the sites within a 1-second grid. The assigned number is retained as a permanent identifier even if a more precise latitude and longitude are later determined.

${ }^{b}$ Well drilled as part of this study. Drilled depth: site 1, $136 \mathrm{ft}$; site 3, $141 \mathrm{ft}$; sites 8 and 9, $387 \mathrm{ft}$; site 10, $44 \mathrm{ft}$; site 11, $41 \mathrm{ft}$; site 13, $456 \mathrm{ft}$; sites 14,15 , and $16,778 \mathrm{ft}$.

${ }^{\mathrm{c} C}$ Collapsed at $15.1 \mathrm{ft}$. 

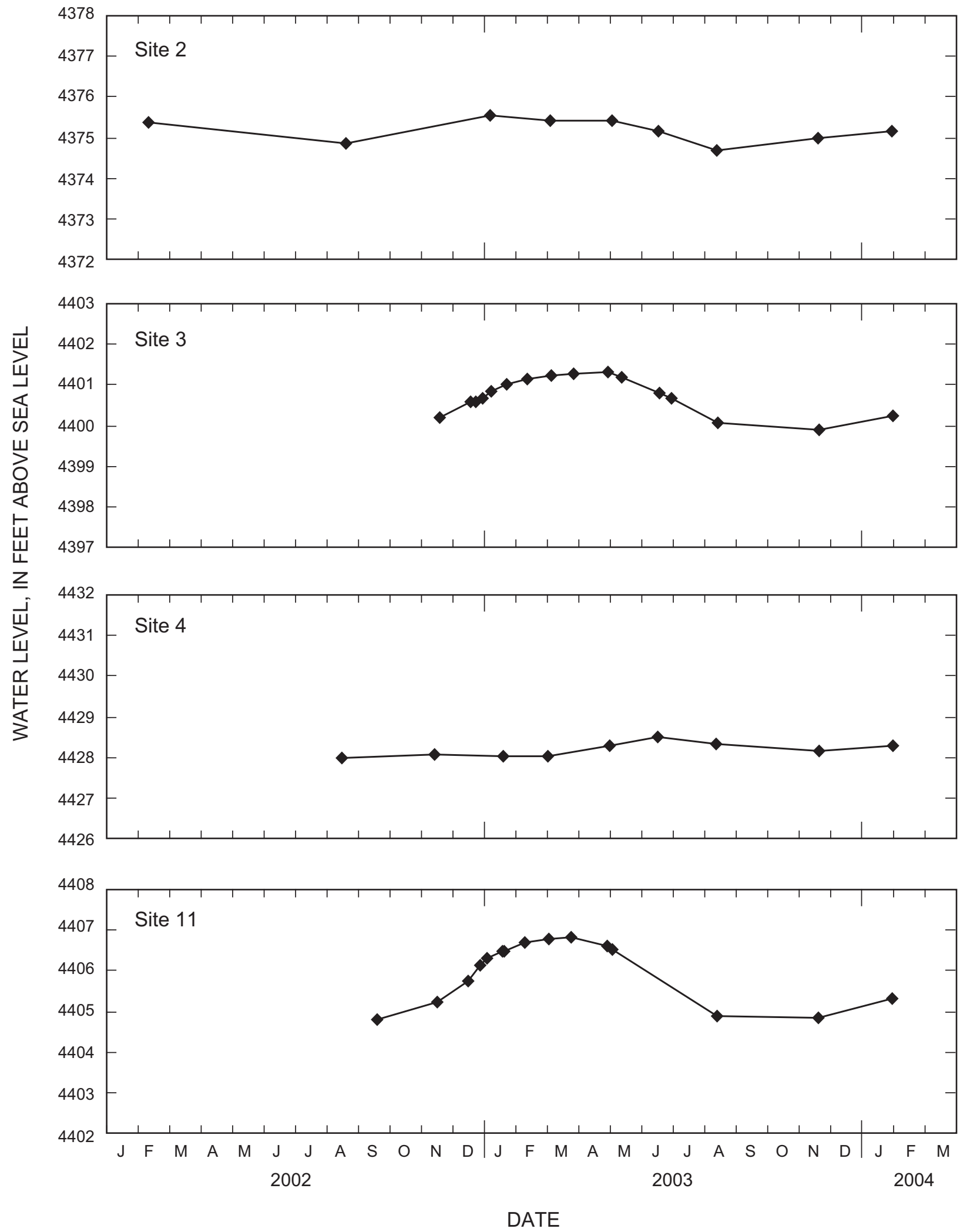

Figure 6. Water-level fluctuations for 2002 through 2003 in selected wells in Dry Valley, west-central Nevada. 


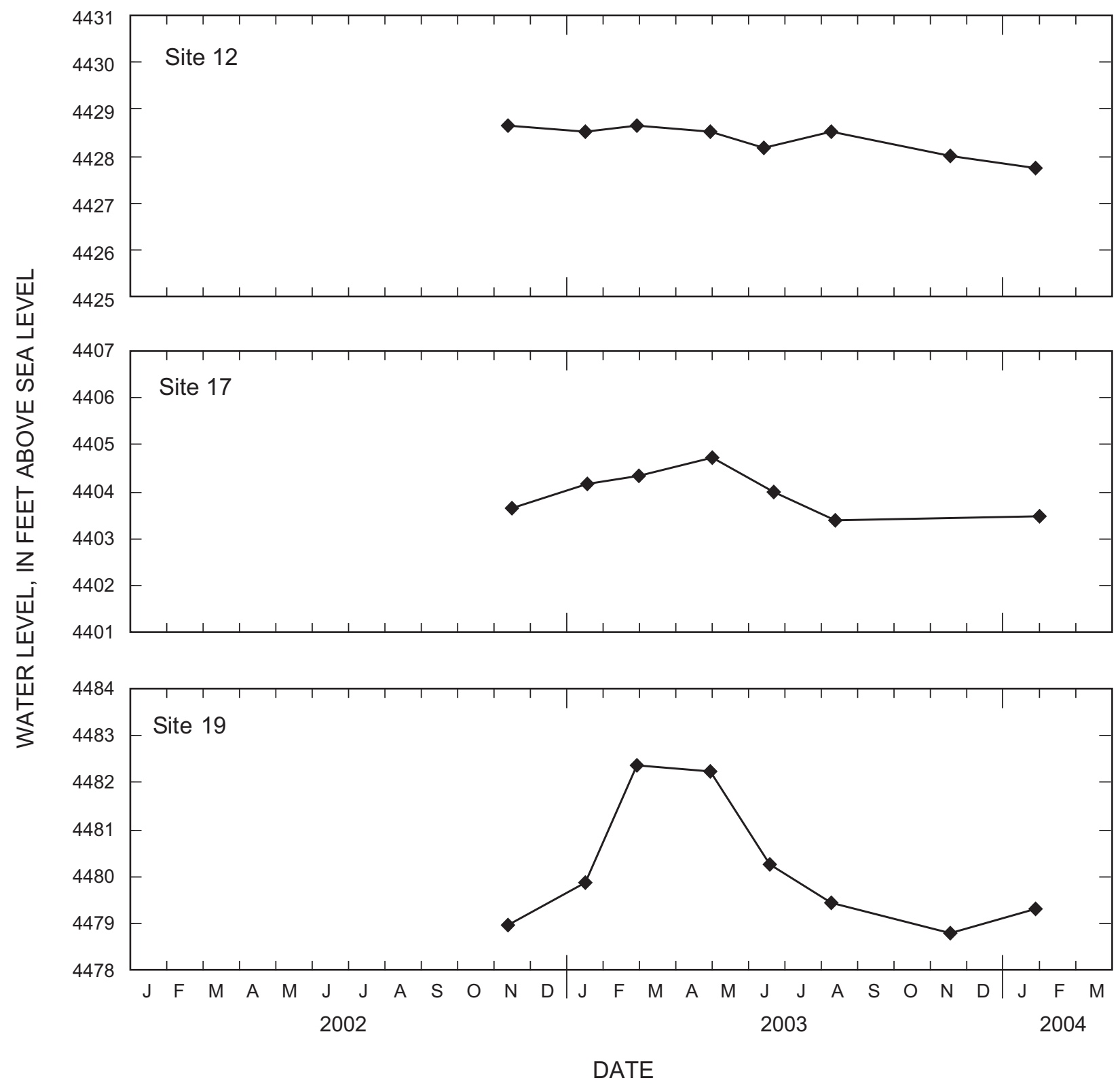

Figure 6.-Continued. 


\section{Ground-Water Discharge}

Natural ground-water discharge from Dry Valley occurs by subsurface outflow to Long Valley and ET by phreatophytic vegetation in areas of shallow ground water. Estimates of subsurface outflow are made by applying Darcy's Law (Health, 1989 , p. 26) and using measured and estimated hydraulic properties of unconsolidated sediments through which flow takes place. Estimates of ET are made from the mapped distribution of phreatophytes and application of ET rates derived from remote sensing techniques developed by Nichols (2000).

\section{Subsurface Outflow}

Subsurface outflow beneath the western boundary of the study area can be estimated directly from Darcy's Law using estimates of transmissivity, the width of unconsolidated sediments through which flow takes place, and the slope of the water table perpendicular to the direction of flow. Subsurface outflow was estimated using the following equation for Darcy's Law as modified from Heath (1989, p. 26):

$$
\mathrm{Q}=0.0084 \mathrm{~T} \mathrm{~W} d h / d l
$$

where $\mathrm{Q}$ is the quantity of subsurface flow in acre-feet per year;
$\mathrm{T}$ is the transmissivity in squared feet per day;

$\mathrm{W}$ is the width of the flow section in feet; $d h / d l$ is the hydraulic gradient, in feet of water-level change per foot of horizontal distance; and

0.0084 is the factor to convert cubic feet per day into acrefeet per year.

Equation 1 was applied to a hydrogeologic cross section across the mouth of Dry Valley coincident with the CaliforniaNevada State line (fig. 7). The cross section was approximately perpendicular to ground-water flow through the mouth of Dry Valley. The section extends from non-welded rhyolitic tuffs on the northern side of the valley floor, through unconsolidated sediments beneath Dry Valley Creek, and into non-welded rhyolitic tuffs on the southern side of the valley (fig. 3). The section is in close proximity to wells installed for this study where lithologic, borehole geophysical, and aquifer-test data are available.

Estimates of the transmissivity of unconsolidated sediments were made from 2 aquifer tests using wells near the mouth of Dry Valley that are completed in unconsolidated sediments (fig. 3). The first test was a multiple-well test of 24-hour duration from May 5 to May 6, 2003. For this test, the irrigation well (site 13) was pumped at an average rate of $415 \mathrm{gal} / \mathrm{min}$., while water levels were recorded at a total of nine observation wells. The observation wells ranged from 100 to $1,700 \mathrm{ft}$ from the pumping well and were screened at depths from 30 to 550 $\mathrm{ft}$. The second aquifer test also was a multiple-well test and con-

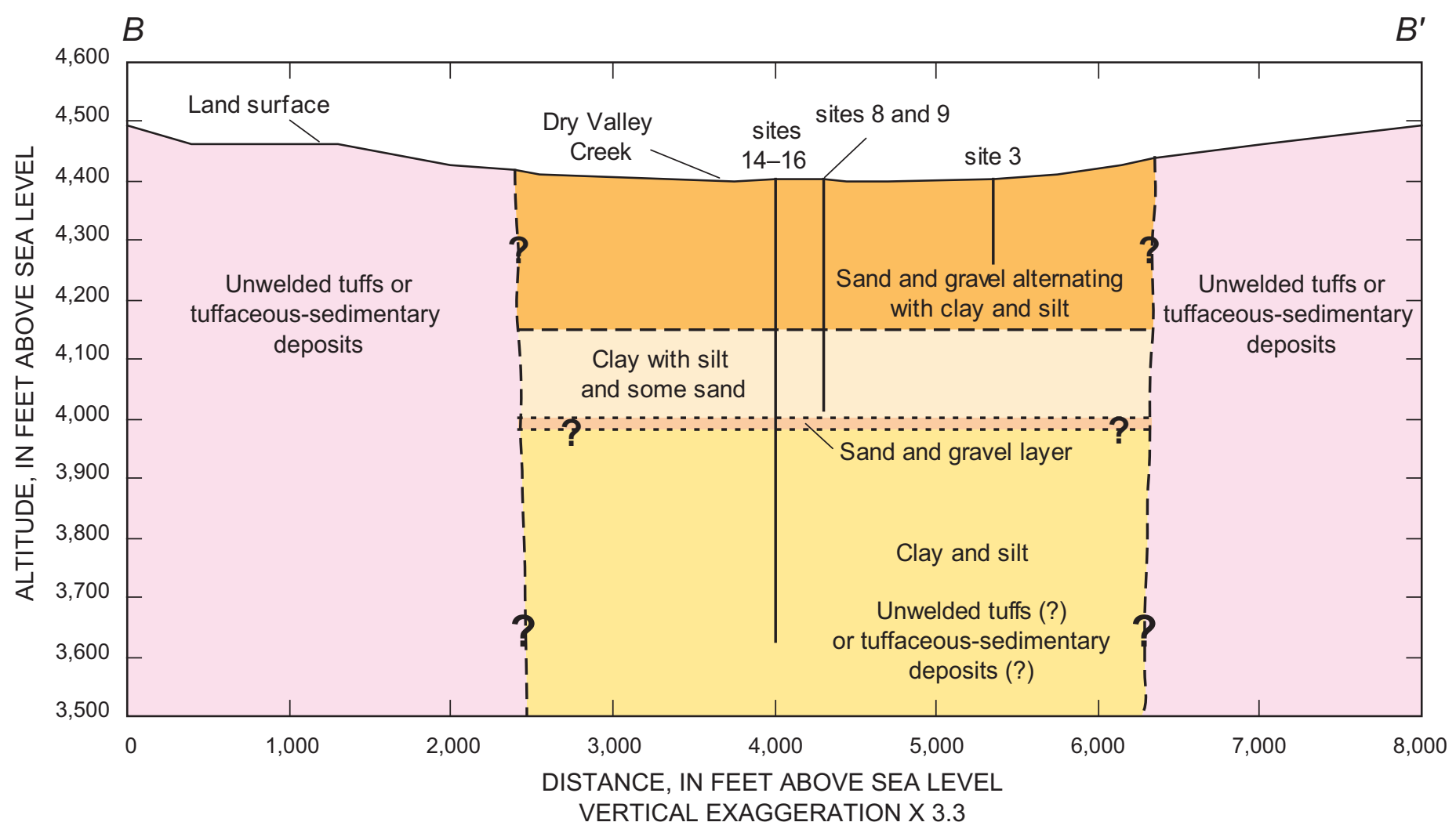

Figure 7. Hydrogeologic cross section $B-B^{\prime}$ near the mouth of Dry Valley, west-central Nevada. 
sisted of pumping a 6-in. diameter well (site 3) installed for this study for a period of four hours on July 10, 2003 at an average rate of $43 \mathrm{gal} / \mathrm{min}$. Water levels were recorded at an observation well about 1,100 ft from the pumped well, but did not respond to pumping during the test.

A transmissivity of $1,500 \mathrm{ft}^{2} / \mathrm{d}$ was estimated initially with the more common single-well aquifer test. Single-well aquifer tests are more common because only one well is needed and analysis tend to be fairly straight forward. Drawdowns from the first aquifer test were analyzed using a straight-line method (Cooper and Jacob, 1946). Effects of partial penetration, aquifer heterogeneity, and water-table conditions were investigated by analyzing the two multiple-well aquifer tests together with a single numerical model.

The analysis was accomplished using the numerical ground-water flow model MODFLOW (McDonald and Harbaugh, 1988; Harbaugh and McDonald, 1996) to simulate twodimensional radial flow. Hydraulic properties of 8 intervals that ranged from 40 to $400 \mathrm{ft}$ in thickness were estimated by minimizing weighted sum-of-squares differences between simulated and measured drawdowns from both aquifer tests (Gill and others, 1981). Transmissivity of the hydrogeologic section was estimated by fitting simulated drawdowns to measured drawdowns from both aquifer tests. A transmissivity of $1,200 \mathrm{ft}^{2} / \mathrm{d}$ was the summation of transmissivities for each of the eight intervals.

Transmissivity estimates ranged from 1,200 to $1,500 \mathrm{ft}^{2} / \mathrm{d}$. The Cooper-Jacob analysis of drawdowns in the single-well test resulted in a transmissivity of $1,500 \mathrm{ft}^{2} / \mathrm{d}$. Results of the model analysis of the multiple-well tests resulted in a similar transmissivity for the entire modeled section of $1,200 \mathrm{ft}^{2} / \mathrm{d}$. These values provide reasonable estimates for the transmissivity of the poorly sorted unconsolidated sediments near the mouth of Dry Valley.

The approximate width of unconsolidated sediments between exposures of the non-welded tuff is about 4,000 ft (figs. 3 and 7). However, $0.5 \mathrm{mi}$. west of the State line the width of the unconsolidated sediments is about $1,500 \mathrm{ft}$, (fig. 3). To provide a range of estimates for subsurface flow, both widths were applied using equation 1.

Based on equation 1, subsurface outflow toward Long Valley from Dry Valley ranges from 50 to 250 acre-ft/yr (table 2). Hydraulic gradients through the cross section ranged from 0.003 to $0.005 \mathrm{ft} / \mathrm{ft}$ (fig. 3). Transmissivity estimates ranged from 1,200 to $1,500 \mathrm{ft}^{2} / \mathrm{d}$. The width of unconsolidated sediments ranged from 1,500 to $4,000 \mathrm{ft}$.

\section{Evapotranspiration}

Satellite data have been used in Nevada to estimate ground-water discharge by ET based on relations between vegetation indices derived from Landsat data and measured plant cover (Nichols, 2000). Nichols (2000, p. A6) determined that ground-water discharge by ET could be estimated as a function of plant cover. Plant cover, in turn, can be determined
Table 2. Estimates of subsurface outflow from Dry Valley, westcentral Nevada

\begin{tabular}{|c|c|c|c|c|c|}
\hline \multirow{2}{*}{$\begin{array}{c}\text { Transmissivity } \\
\text { (square feet } \\
\text { per day) }\end{array}$} & \multirow[t]{2}{*}{$\begin{array}{l}\text { Width } \\
\text { (feet) }\end{array}$} & \multicolumn{2}{|c|}{$\begin{array}{l}\text { Hydraulic gradient } \\
\text { (foot per foot) }\end{array}$} & \multicolumn{2}{|c|}{$\begin{array}{l}\text { Subsurface outflow, } \\
\text { rounded }^{1} \\
\text { (acre-feet/ per year) }\end{array}$} \\
\hline & & Minimum & Maximum & Minimum & Maximum \\
\hline 1,200 & 4,000 & 0.003 & 0.005 & 120 & 200 \\
\hline 1,500 & 4,000 & 0.003 & 0.005 & 150 & 250 \\
\hline 1,200 & 1,500 & 0.003 & 0.005 & 50 & 80 \\
\hline 1,500 & 1,500 & 0.003 & 0.005 & 60 & 100 \\
\hline
\end{tabular}

${ }^{1}$ Calculated using equation 1 , see section titled "Subsurface Outflow".

from Landsat data using easily calculated vegetation indices (Nichols, 2000, p. B6). The relation between vegetation indices and plant cover was used together with the relation between plant cover and ET rates to determine annual estimates of ground-water discharge by phreatophytic vegetation in Dry Valley.

Ground-water discharge by ET ranges from 640 to 790 acre-ft/yr in Dry Valley (table 3). The area of groundwater discharge by ET in Dry Valley was field mapped during the summer of 2002 and 2003 (fig. 8). Outside the boundary of the mapped area, the depth of ground water was assumed to be too deep for phreatophytes to grow. Within the boundary, depth of water is shallow and plants growing there are using ground water, or ground water can evaporate directly through bare soil. The mapped area consisted of about 620 acres of phreatophytic vegetation and about 1,500 acres of bare soil. Landsat data used to derive plant cover and compute annual ET rates were obtained July 8, 2003. Areas of plant cover corresponding to less than 10 percent, 20 to 35 percent, 35 to greater than 50 percent, and bare soil were determined from the Landsat image and field mapping. Estimated ET rates for mapped plant covers in Dry Valley ranged from 0.17 to $2.6 \mathrm{ft} / \mathrm{yr}$, with an average rate for all zones about $1.5 \mathrm{ft} / \mathrm{yr}$. Using the relations developed by Nichols (2000, p. B6), ET rates for each plant-cover zone were multiplied by the corresponding area to estimate annual groundwater discharge by ET.

\section{Discussion of Discharge Estimates}

Estimates of natural ground-water discharge from Dry Valley range from a minimum of about 700 to a maximum of about 1,000 acre-ft/yr (table 4). The estimate of 50 to $250 \mathrm{acre}-\mathrm{ft} / \mathrm{yr}$ of subsurface outflow (table 2) to Long Valley, Calif. is smaller than the discharge estimates of 2,300 acre-ft/yr by Rush and Glancy (1967, p. 37) and 4,500 acre-ft/yr by Stantec Consulting Inc. and Cordilleran Hydrology (2000, p. 16). Although the hydraulic gradient is similar, the flow width is less than half and estimates of transmissivity are only about 


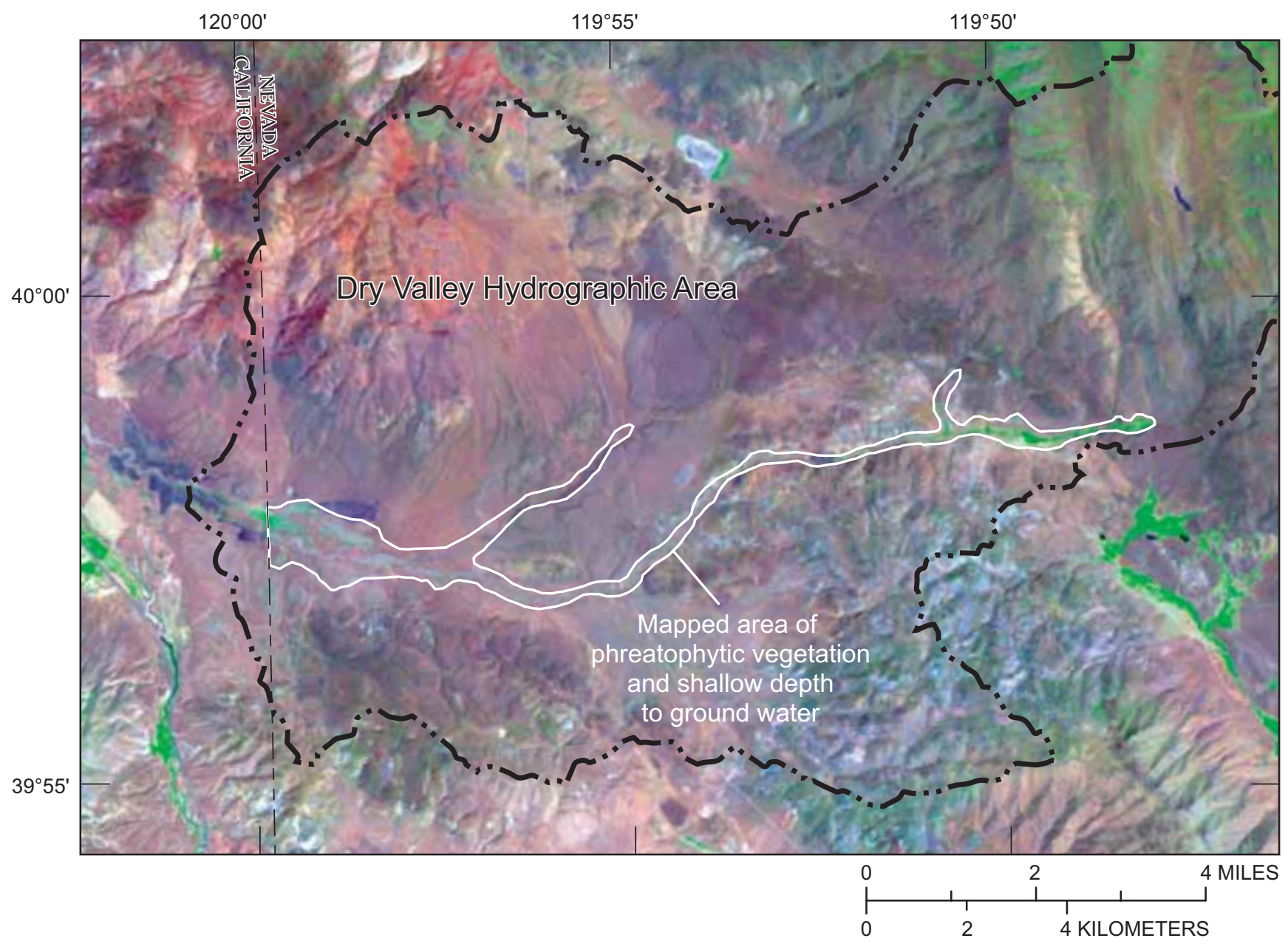

Figure 8. Area of phreatophytic vegetation and shallow depth to ground water. Satellite imagery recorded with enhanced thematic mapper on USGS Landsat 7, Scene ID LE7043032000218950, obtained July 8, 2003, Dry Valley area, west-central Nevada.

12 to 20 percent of that used by the previous studies (Rush and Glancy, 1967, p. 37; Stantec Consulting Inc. and Cordilleran Hydrology, 2000, p. 16). The shorter flow width is based on more recent geologic mapping of the poorly permeable nonwelded rhyolitic tuffs that lie along the State line. Transmissivity values used in this study for sediments near the State line are based on the results of drilling, borehole-geophysical logs, and two aquifer tests in boreholes along the State line.

Ground-water discharge by ET of 640 to 790 acre-ft/yr (table 3) is greater than the discharge of 80 acre- $\mathrm{ft} / \mathrm{yr}$ by Rush and Glancy (1967, p. 33) and similar to the estimate of 500 acre-ft/yr by Stantec Consulting Inc. and Cordilleran Hydrology (2000, p. 21). The difference in estimates is due to a greater and more detailed mapped area of phreatophytic vegetation and higher ET rates being used in this report. The higher ET rates are based on Nichols (2000), which in turn are based, in part, on field-measurement studies. Areas of bare soil, where ground-water discharge by ET takes place from the shallow water table, was apparently not considered by either study, and accounts for more than one third of the estimate.

Thomas and Albright (2003, p. 19-22) estimate average ground-water recharge from precipitation to range from 1,400 to 4,800 acre-ft/yr and suggest that an overall range is 0 to
$17,000 \mathrm{acre}-\mathrm{ft} / \mathrm{yr}$. Their recharge estimates are based on the chloride mass-balance method and assumes that about 63,000 acre-ft of precipitation falls in recharge source areas and is available for ground-water recharge. As part of this study, the maximum estimate of natural ground-water discharge from Dry Valley of about 1,000 acre-ft/yr is in fairly good agreement with the average minimum estimate of 1,400 acre-ft/yr of Thomas and Albright (2003, p. 22).

\section{Water Quality and Geochemistry}

Ground-water samples were collected from 5 springs during January and March 2003 and from 3 wells screened in unconsolidated sediments during May and June 2003 (fig. 2; table 5). Field parameters ( $\mathrm{pH}$, dissolved oxygen, specific conductance, and water temperature) were measured on-site. Samples were collected directly from actively flowing springs and as close to the orifice as possible. At each well, a minimum of three well volumes were pumped prior to sample collection. Ground water was pumped through a flow-through cell and field parameters were monitored until they stabilized (Wilde and others, 1999). 
Table 4. Estimates of natural ground-water discharge from Dry Valley, west-central Nevada

\begin{tabular}{lcc}
\hline Discharge component & $\begin{array}{c}\text { Natural ground-water } \\
\text { discharge } \\
\text { (acre-feet per year) }\end{array}$ \\
\cline { 2 - 3 } & Minimum & Maximum \\
\hline Subsurface outflow & 50 & 250 \\
Evapotranspiration & 640 & 790 \\
\hline Total (rounded) & 700 & 1,000 \\
\hline
\end{tabular}

Samples for dissolved constituents were filtered in the field using 0.45 micron filters. Samples for cations and trace elements were preserved to a $\mathrm{pH}$ of less than 2 , using concentrated ultra-pure nitric acid, and samples for nutrients were chilled on ice. Alkalinity was measured in the field by incremental titration. Samples were analyzed for major ions, trace elements, nutrients, and dissolved solids at the USGS National Water-Quality Laboratory in Denver, Colorado. Stable isotopes of oxygen and hydrogen were analyzed at the USGS Stable Isotope Laboratory in Reston, Virginia.

Data collected by previous investigations were examined for a more complete characterization of water quality and geochemical interpretation of the ground-water system, but are not reproduced in this report (table 5). The Desert Research Institute (Thomas and Albright, 2003, p. 9-10) analyzed major ions and isotopes of oxygen and hydrogen in an additional 21 samples (fig.2; DRI 1 through 21) collected from springs in June and July 2003. Three of the springs sampled by Thomas and Albright (2003) also were sampled for this study (table 5; sites 24, 25, and 26). Constituent concentrations and field parameters measured by the USGS and Thomas and Albright (2003) were similar for the three springs, indicating results are comparable. In March 2003, Bootlegger Spring (DRI 15) and Upper and Lower Willow Springs (DRI 16 and 17) were dry and Gooseberry Spring and Higgens Spring (DRI 1 and 7) were stagnant and were not sampled. However, Thomas and Albright (2003, p. 9-10) collected samples from these springs in June and July 2003. Spring discharge apparently resumed after heavy precipitation in April 2003.

Stream samples from the lower reaches of Dry Valley Creek and North Fork Dry Valley Creek were sampled on April 5, 2000 (Stantec Consulting, Inc. and Cordilleran Hydrology, 2000 , p. 19). Samples were analyzed for major ions, nitrate, dissolved solids, and trace elements by the Nevada State Health Laboratory. Except for high pH (8.9 and 9.35), concentrations of all other constituents were similar to ground-water samples. 
Table 5. Results of chemical analyses for water samples from selected well and spring sites, Dry Valley, west-central Nevada

[Abbreviations and symbols: mg/L, milligrams per liter; $\mu \mathrm{g} / \mathrm{L}$, micrograms per liter; $\mu \mathrm{S} / \mathrm{cm}$, microsiemens per centimeter; ${ }^{\circ} \mathrm{C}$, degrees Celsius; <, less than; E, estimated value; M, presence verified, not quantified; --, not determined; Deuterium and oxygen are relative to Vienna Standard Mean Ocean Water.].

\begin{tabular}{|c|c|c|c|c|c|c|c|c|c|c|c|}
\hline $\begin{array}{l}\text { Site } \\
\text { number } \\
\text { (fig. 2) }\end{array}$ & $\begin{array}{c}\text { Standard } \\
\text { identification }\end{array}$ & $\begin{array}{c}\text { Date } \\
\text { sampled }\end{array}$ & $\begin{array}{c}\text { Specific } \\
\text { conductance } \\
(\mu \mathrm{S} / \mathrm{cm})\end{array}$ & $\begin{array}{c}\mathrm{pH} \\
\text { (standard } \\
\text { units) }\end{array}$ & $\begin{array}{c}\text { Water } \\
\text { temperature } \\
\left({ }^{\circ} \mathrm{C}\right)\end{array}$ & $\begin{array}{c}\text { Dissolved } \\
\text { oxygen, } \\
\text { (mg/L) }\end{array}$ & $\begin{array}{l}\text { Calcium } \\
\text { (mg/L) }\end{array}$ & $\begin{array}{l}\text { Magnesium } \\
(\mathrm{mg} / \mathrm{L})\end{array}$ & $\begin{array}{l}\text { Sodium } \\
\text { (mg/L) }\end{array}$ & $\begin{array}{l}\text { Potassium } \\
\text { (mg/L) }\end{array}$ & $\begin{array}{c}\text { Alkalinity } \\
\text { as } \mathrm{CaCO}_{3} \\
\text { (mg/L) }\end{array}$ \\
\hline \multicolumn{12}{|c|}{ Well sites } \\
\hline 9 & 395737119595503 & $05-14-03$ & 435 & 7.4 & 15.5 & 0.2 & 26.5 & 13.8 & 51.6 & 3.39 & 190 \\
\hline 14 & 395734119595501 & $05-07-03$ & 530 & 7.4 & 12.5 & .1 & 22.0 & 9.75 & 86.9 & 2.48 & 208 \\
\hline 19 & 395657119571601 & $06-25-03$ & 528 & 7.5 & 18.5 & 5.6 & 35.3 & 20.2 & 53.4 & 2.00 & 210 \\
\hline \multicolumn{12}{|c|}{ Spring sites } \\
\hline \multirow[t]{2}{*}{24} & 395846119515801 & $01-22-02$ & -- & -- & -- & -- & -- & -- & -- & -- & -- \\
\hline & & $03-11-03$ & 134 & 6.3 & 12.0 & 6.2 & 2.76 & .851 & 21.1 & 2.67 & 33 \\
\hline \multirow[t]{2}{*}{25} & 395704119564501 & $01-22-02$ & -- & -- & -- & -- & -- & -- & -- & -- & -- \\
\hline & & $01-23-03$ & 339 & 6.7 & 13.0 & 5.6 & 3.79 & 1.33 & 73.0 & 2.01 & 128 \\
\hline 26 & 395620119590901 & $01-23-03$ & 260 & 7.6 & 9.5 & 11.5 & 23.0 & 14.6 & 15.4 & 1.91 & 133 \\
\hline 27 & 395523119553901 & $01-23-03$ & 380 & 7.4 & 9.0 & 5.2 & 12.3 & 2.89 & 67.0 & 3.73 & 124 \\
\hline 28 & 395516119510201 & $03-11-03$ & 300 & 7.2 & 7.2 & 6.5 & 50.4 & .581 & 14.9 & 1.04 & 139 \\
\hline
\end{tabular}

\begin{tabular}{|c|c|c|c|c|c|c|c|c|c|c|c|}
\hline $\begin{array}{c}\text { Site } \\
\text { number } \\
\text { (fig. 2) }\end{array}$ & $\begin{array}{l}\text { Sulfate } \\
\text { (mg/L) }\end{array}$ & $\begin{array}{l}\text { Chloride } \\
\text { (mg/L) }\end{array}$ & $\begin{array}{l}\text { Fluoride } \\
\text { (mg/L) }\end{array}$ & $\begin{array}{l}\text { Bromide } \\
\text { (mg/L) }\end{array}$ & $\begin{array}{l}\text { Silica } \\
\text { (mg/L) }\end{array}$ & $\begin{array}{l}\text { Residue on } \\
\text { evaporation } \\
\text { (mg/L) }\end{array}$ & $\begin{array}{l}\text { Nitrite plus } \\
\text { nitrate } \\
\text { (mg/L) }\end{array}$ & $\begin{array}{l}\text { Nitrite } \\
\text { (mg/L) }\end{array}$ & $\begin{array}{c}\text { Ammonia } \\
\text { plus } \\
\text { organic } \\
\text { nitrogen } \\
\text { (mg/L) }\end{array}$ & $\begin{array}{c}\text { Ammonia } \\
\text { (mg/L) }\end{array}$ & $\begin{array}{l}\text { Orthophosphate } \\
\text { (mg/L) }\end{array}$ \\
\hline \multicolumn{12}{|c|}{ Well sites } \\
\hline 9 & 15.8 & 10.4 & .23 & .09 & 62.9 & 303 & .80 & E.004 & $<.10$ & $<.04$ & .12 \\
\hline 14 & 29.8 & 14.8 & .37 & .12 & 46.1 & 353 & $<.06$ & $<.008$ & .24 & .17 & 4.26 \\
\hline 19 & 20.0 & 19.6 & .5 & .17 & 55.8 & 347 & .94 & E.005 & E.07 & $<.04$ & .17 \\
\hline \multicolumn{12}{|c|}{ Spring sites } \\
\hline 24 & -- & -- & -- & -- & -- & -- & -- & -- & -- & -- & -- \\
\hline & 10.8 & 8.67 & .10 & .07 & 58.5 & 142 & 1.79 & $<.008$ & $<.10$ & $<.04$ & .07 \\
\hline \multirow[t]{2}{*}{25} & -- & -- & -- & -- & -- & -- & -- & -- & -- & -- & -- \\
\hline & 23.1 & 10.8 & .40 & .08 & 57.0 & 254 & .83 & $<.008$ & .13 & E.02 & .11 \\
\hline 26 & 4.5 & 3.07 & $<.17$ & .04 & 47.2 & 187 & 1.31 & $<.008$ & E.05 & $<.04$ & .04 \\
\hline 27 & 29.4 & 23.1 & .25 & .16 & 48.7 & 268 & E.04 & $<.008$ & .23 & .04 & .46 \\
\hline 28 & 6.6 & 6.80 & .07 & .04 & 31.5 & 203 & .30 & $<.008$ & $<.10$ & $<.04$ & E.01 \\
\hline
\end{tabular}


Table 5. Results of chemical analyses for water samples from selected springs and well sites, Dry Valley, west-central Nevada—Continued

\begin{tabular}{|c|c|c|c|c|c|c|c|c|c|c|c|c|c|}
\hline $\begin{array}{c}\text { Site } \\
\text { number } \\
\text { (fig. 2) }\end{array}$ & $\begin{array}{l}\text { Aluminum } \\
(\mu \mathrm{g} / \mathrm{L})\end{array}$ & $\begin{array}{c}\text { Antimony } \\
(\mu \mathrm{g} / \mathrm{L})\end{array}$ & $\begin{array}{c}\text { Arsenic } \\
(\mu \mathrm{g} / \mathrm{L})\end{array}$ & $\begin{array}{l}\text { Barium } \\
(\mu \mathrm{g} / \mathrm{L})\end{array}$ & $\begin{array}{l}\text { Beryllium } \\
(\mu \mathrm{g} / \mathrm{L})\end{array}$ & $\begin{array}{l}\text { Boron } \\
(\mu \mathrm{g} / \mathrm{L})\end{array}$ & $\begin{array}{l}\text { Cadmium } \\
(\mu \mathrm{g} / \mathrm{L})\end{array}$ & $\begin{array}{l}\text { Chromium } \\
\qquad(\mu \mathrm{g} / \mathrm{L})\end{array}$ & $\begin{array}{l}\text { Cobalt } \\
(\mu \mathrm{g} / \mathrm{L})\end{array}$ & $\begin{array}{c}\text { Copper } \\
(\mu \mathrm{g} / \mathrm{L})\end{array}$ & $\begin{array}{l}\text { Iron } \\
(\mu \mathrm{g} / \mathrm{L})\end{array}$ & $\begin{array}{l}\text { Lead } \\
(\mu \mathrm{g} / \mathrm{L})\end{array}$ & $\begin{array}{c}\text { Lithium } \\
(\mu \mathrm{g} / \mathrm{L})\end{array}$ \\
\hline \multicolumn{14}{|c|}{ Well sites } \\
\hline 9 & E1 & $<.30$ & 7.5 & 39 & $<.06$ & 33 & .04 & 1.1 & .14 & .6 & $<10$ & $<.08$ & .6 \\
\hline 14 & 2 & .35 & 6.9 & 48 & $<.06$ & 59 & .04 & $<.8$ & .47 & .6 & 19 & $<.08$ & 1.6 \\
\hline 19 & M & E.17 & 5.0 & 50 & $<.06$ & 52 & E.03 & $<.8$ & .23 & 5.5 & $<8$ & .18 & .7 \\
\hline \multicolumn{14}{|c|}{ Spring sites } \\
\hline \multirow[t]{2}{*}{24} & -- & -- & -- & -- & -- & -- & -- & -- & -- & -- & -- & -- & -- \\
\hline & 9 & $<.30$ & 1.6 & 8 & $<.06$ & 44 & $<.04$ & $<.8$ & .02 & E. 2 & $<10$ & $<.08$ & 5.2 \\
\hline \multirow[t]{2}{*}{25} & -- & -- & -- & -- & -- & -- & -- & -- & -- & -- & -- & -- & -- \\
\hline & E1 & $<.30$ & 9.4 & 5 & $<.06$ & 395 & .07 & $<.8$ & .10 & .4 & $<10$ & $<.08$ & 37.3 \\
\hline 26 & 2 & $<.30$ & 1.8 & 14 & $<.06$ & 14 & $<.04$ & $<.8$ & .08 & .4 & $<10$ & $<.08$ & 2.1 \\
\hline 27 & 3 & E.19 & 6.3 & 10 & $<.06$ & 62 & E.02 & $<.8$ & .05 & .4 & $<10$ & $<.08$ & 16.3 \\
\hline 28 & $<2$ & E. 20 & 2.5 & 36 & $<.06$ & 11 & $<.04$ & $<.8$ & .10 & E.2 & E9 & .10 & 12.4 \\
\hline
\end{tabular}

\begin{tabular}{|c|c|c|c|c|c|c|c|c|c|c|c|c|}
\hline $\begin{array}{l}\text { Site } \\
\text { number } \\
\text { (fig. 2) }\end{array}$ & $\begin{array}{c}\text { Manganese } \\
(\mu \mathrm{g} / \mathrm{L})\end{array}$ & $\begin{array}{l}\text { Molybdenum } \\
(\mu \mathrm{g} / \mathrm{L})\end{array}$ & $\begin{array}{l}\text { Nickel } \\
(\mu \mathrm{g} / \mathrm{L})\end{array}$ & $\begin{array}{l}\text { Selenium } \\
(\mu \mathrm{g} / \mathrm{L})\end{array}$ & $\begin{array}{l}\text { Silver } \\
(\mu \mathrm{g} / \mathrm{L})\end{array}$ & $\begin{array}{l}\text { Strontium } \\
(\mu \mathrm{g} / \mathrm{L})\end{array}$ & $\begin{array}{l}\text { Thallium } \\
(\mu \mathrm{g} / \mathrm{L})\end{array}$ & $\begin{array}{l}\text { Vanadium } \\
(\mu \mathrm{g} / \mathrm{L})\end{array}$ & $\begin{array}{l}\text { Uranium } \\
(\mu \mathrm{g} / \mathrm{L})\end{array}$ & $\begin{array}{l}\text { Zinc } \\
(\mu \mathrm{g} / \mathrm{L})\end{array}$ & $\begin{array}{c}\text { Delta } \\
\text { deuterium } \\
\text { (per mil) }\end{array}$ & $\begin{array}{c}\text { Delta } \\
\text { oxygen-18 } \\
\text { (per mil) }\end{array}$ \\
\hline \multicolumn{13}{|c|}{ Well sites } \\
\hline 9 & 51.3 & 8.9 & .87 & E.5 & $<.20$ & 189 & $<.04$ & 41.9 & 4.71 & M & -113 & -14.62 \\
\hline 14 & 407 & 13.7 & 1.93 & $<.5$ & $<.20$ & 208 & $<.04$ & 3.4 & 1.13 & 1 & -112 & -14.30 \\
\hline 19 & 103 & 5.3 & 1.1 & E. 5 & $<.20$ & 333 & $<.04$ & 22.9 & 3.89 & 239 & -105 & -13.45 \\
\hline \multirow[t]{2}{*}{24} & -- & -- & -- & -- & -- & -- & -- & -- & -- & -- & -112 & -14.24 \\
\hline & .5 & .7 & .21 & E. 3 & $<.20$ & 26.2 & $<.04$ & 1.8 & .30 & M & -113 & -14.34 \\
\hline \multirow[t]{2}{*}{25} & -- & -- & -- & -- & -- & -- & -- & -- & -- & -- & -116 & -14.58 \\
\hline & 18.8 & 24.4 & .35 & E. 3 & $<.20$ & 27.4 & $<.04$ & 4.4 & 4.07 & M & -114 & -14.34 \\
\hline 26 & .6 & .4 & 1.04 & E. 4 & $<.20$ & 164 & $<.04$ & 12.6 & 1.19 & $<1$ & -112 & -14.39 \\
\hline 27 & .8 & 2.4 & .65 & 1.0 & $<.20$ & 54.0 & $<.04$ & 5.5 & 2.99 & $\mathrm{M}$ & -112 & -14.62 \\
\hline 28 & 6.2 & E. 2 & 2.31 & $<.5$ & $<.20$ & 178 & $<.04$ & 1.8 & 5.12 & M & -115 & -14.94 \\
\hline
\end{tabular}




\section{Estimates of Natural Ground-Water Discharge and Characterization of Water Quality in Dry Valley, 2002-2003}

\section{Water Quality}

Concentrations of selected constituents were compared to primary and secondary drinking-water standards (table 6). Primary standards are an enforceable, maximum concentration allowed in public water supplies; secondary standards are not enforceable. No primary drinking-water standards were exceeded for any of the constituents that were analyzed. Samples from the three wells exceeded the secondary standard for manganese. One spring sample (site 24) and both stream samples were outside the range for the secondary standard for $\mathrm{pH}$.

Manganese can discolor water, cause black staining, and leaves a bitter taste. Low $\mathrm{pH}$ water can leave a bitter, metallic taste and corrode metal pipes. High $\mathrm{pH}$ water can have a slippery feel, a soda taste, and cause deposits in pipes. Samples were not analyzed for all inorganic constituents that have a primary drinking-water standard or for organic contaminants. Organic contaminants were not analyzed because Dry Valley is undeveloped and has no known sources of pesticides, volatile organic compounds, or other anthropogenic contaminants.

\section{Geochemistry of Ground Water and Streams}

Dry Valley has two primary types of water chemistry that are distinguishable by ratios of cations, and are related to the lithology of the geologic units. The first primary water type is characterized by the sodium-bicarbonate chemistry of a spring near an outcrop of welded tuff of the Hartford Hill Rhyolite in the center of the basin (site 25, DRI 21; figs. 2 and 9). The second primary water type is represented by samples from Dry Valley Creek and several springs in the Virginia, Seven Lakes, and Fort Sage Mountains and has a calcium-magnesium-bicarbonate chemistry (fig. 9). Much of these mountains are comprised of basaltic rocks of the Pyramid Sequence which overlie the Hartford Hill Rhyolite. The higher ratio of calcium and magnesium to sodium observed in the second primary water type likely is due to the mafic to intermediate chemistry associated with the Pyramid Sequence. The different chemistry represented by site 25 indicates a different source area of recharge than that of the second primary water type. Ground water discharging at the spring (site 25 ) has probably moved through the Hartford Hill Rhyolite exposed up gradient over the entire northern end of Dogskin Mountain. The absence of the Pyramid Sequence along this flow path would explain this unique chemistry observed in the center of the basin.

The Hartford Hill Rhyolite has about two times more sodium than calcium or magnesium (Bonham, 1969, p. 24). The sodium-bicarbonate chemistry of site 25 likely is due to dissolution of albite, a sodium feldspar that is a common silicate mineral in rhyolite (Hurlbert and Klein, 1977, p. 430). Hydrolysis of silicate minerals occurs by a sequence of reactions that begin when carbon dioxide in the atmosphere forms carbonic acid in water (eq. 2). Carbonic acid dissociates to yield hydrogen and
Table 6. Comparison of selected inorganic constituents for primary and secondary drinking-water standards, in Dry Valley, west-central Nevada

[Abbreviations and symbols: mg/L, milligrams per liter; $\mu \mathrm{g} / \mathrm{L}$, micrograms per liter; $<$, less than; TT, a required process intended to reduce the level of a contaminant in drinking water.]

\begin{tabular}{|c|c|c|}
\hline Contaminant & $\begin{array}{l}\text { Maximum } \\
\text { allowed } \\
\text { concentration }\end{array}$ & $\begin{array}{c}\text { Maximum measured } \\
\text { concentration } \\
\text { (see table 5) }\end{array}$ \\
\hline \multicolumn{3}{|c|}{ Primary drinking water standards } \\
\hline Antimony $(\mu \mathrm{g} / \mathrm{L})$ & 6 & $<.35$ \\
\hline Arsenic $(\mu \mathrm{g} / \mathrm{L})$ & $\mathrm{a}_{10}$ & 9.4 \\
\hline Barium $(\mu \mathrm{g} / \mathrm{L})$ & 2000 & 0.050 \\
\hline Beryllium $(\mu \mathrm{g} / \mathrm{L})$ & 4 & $<0.06$ \\
\hline Cadmium $(\mu \mathrm{g} / \mathrm{L})$ & 5 & 0.07 \\
\hline Chromium (total, $\mu \mathrm{g} / \mathrm{L}$ ) & 100 & 1.1 \\
\hline Copper $(\mu \mathrm{g} / \mathrm{L})$ & $1,300(\mathrm{TT})$ & 5.5 \\
\hline Fluoride (mg/L) & 4 & 0.40 \\
\hline Lead $(\mu \mathrm{g} / \mathrm{L})$ & $15(\mathrm{TT})$ & 0.10 \\
\hline Nitrate $(\mathrm{mg} / \mathrm{L})$ & 10 & 1.79 \\
\hline Nitrite (mg/L) & 1 & $<0.008$ \\
\hline Selenium $(\mu \mathrm{g} / \mathrm{L})$ & 50 & 1.0 \\
\hline Thallium $(\mu \mathrm{g} / \mathrm{L})$ & 2 & $<0.04$ \\
\hline Uranium $(\mu \mathrm{g} / \mathrm{L})$ & 30 & 5.12 \\
\hline \multicolumn{3}{|c|}{ Secondary drinking water standards } \\
\hline Aluminum $(\mu \mathrm{g} / \mathrm{L})$ & 50 to 200 & 9 \\
\hline Chloride (mg/L) & 250 & 23.1 \\
\hline Copper $(\mu \mathrm{g} / \mathrm{L})$ & 1,000 & 5.5 \\
\hline Fluoride $(\mathrm{mg} / \mathrm{L})$ & 2 & 0.40 \\
\hline Iron $(\mu \mathrm{g} / \mathrm{L})$ & 300 & 19 \\
\hline Manganese ( $\mu \mathrm{g} / \mathrm{L})$ & 50 & 407 \\
\hline $\mathrm{pH}$ (standard units) & $6.5-8.5$ & $6.3-7.5$ \\
\hline Silver $(\mu \mathrm{g} / \mathrm{L})$ & 100 & $<0.2$ \\
\hline Sulfate (mg/L) & 250 & 29.8 \\
\hline Zinc $(\mu \mathrm{g} / \mathrm{L})$ & 5,000 & 239 \\
\hline Dissolved solids (mg/L) & 500 & 353 \\
\hline
\end{tabular}

${ }^{a}$ Effective date January 23, 2006

bicarbonate ions (eq. 3). Hydrogen ions then react with albite, forming kaolinite and releasing silica and sodium ions (eq. 4; Hem, 1985, p. 62):

$$
\begin{gathered}
\mathrm{CO}_{2}(\mathrm{~g})+\mathrm{H}_{2} \mathrm{O}=\mathrm{H}_{2} \mathrm{CO}_{3}(\mathrm{aq}) \\
2 \mathrm{H}_{2} \mathrm{CO}_{3}(\mathrm{aq})=2 \mathrm{H}^{+}+2 \mathrm{HCO}_{3}^{-} \\
2 \mathrm{NaAlSi}_{3} \mathrm{O}_{8}(\mathrm{c})+2 \mathrm{H}^{+}+9 \mathrm{H}_{2} \mathrm{O}(1)=\mathrm{Al}_{2} \mathrm{Si}_{2} \mathrm{O}_{5}(\mathrm{OH})_{4}(\mathrm{c})+ \\
4 \mathrm{H}_{4} \mathrm{SiO}_{4}(\mathrm{aq})+2 \mathrm{Na}^{+}
\end{gathered}
$$




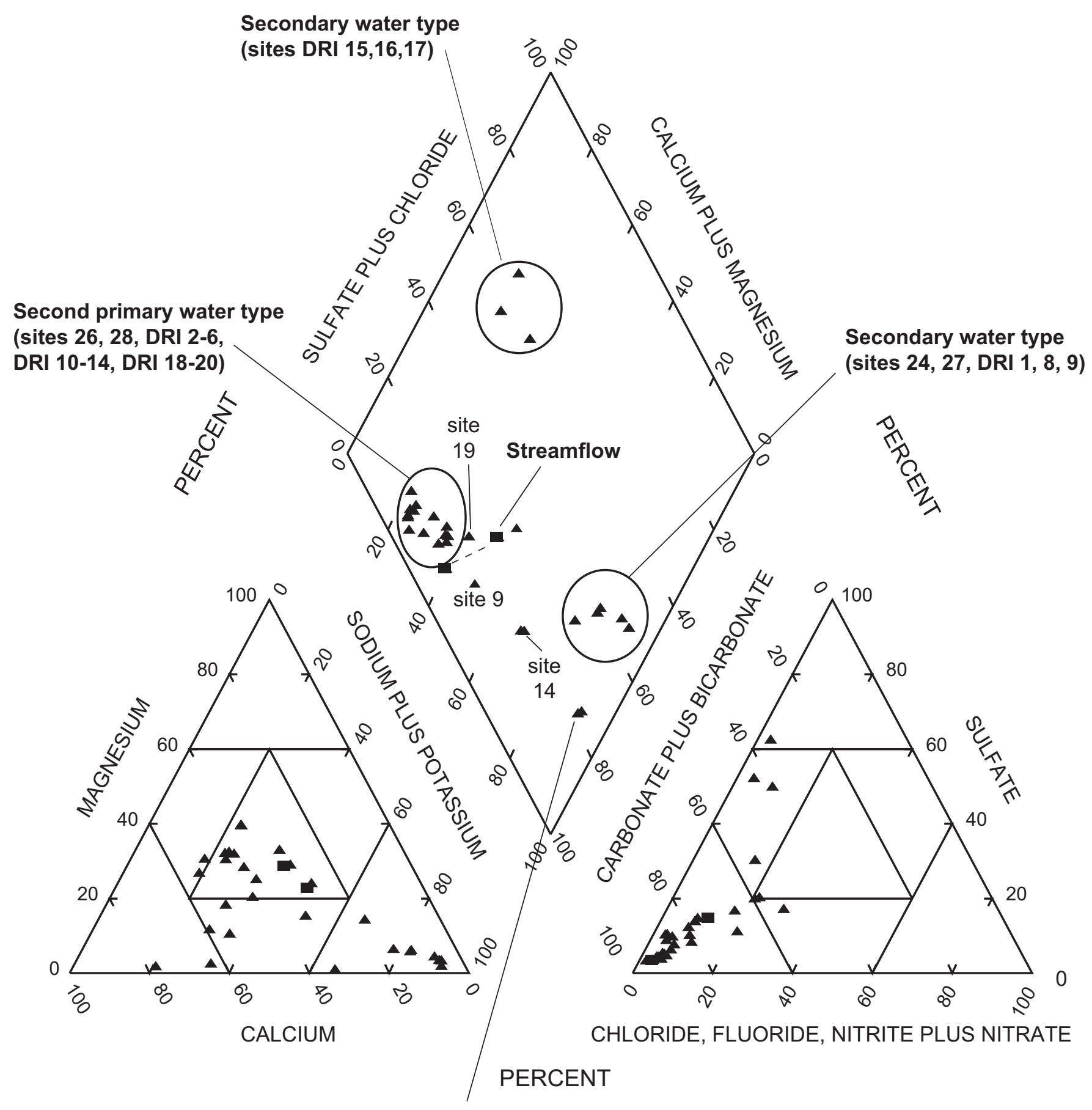

First primary water type (sites 25, DRI 21)

Figure 9. Ratios of major ion chemistry for water sampled in Dry Valley, west-central Nevada. 


\section{Estimates of Natural Ground-Water Discharge and Characterization of Water Quality in Dry Valley, 2002-2003}

The sodium and bicarbonate produced by these reactions explain the chemistry of site 25 . A similar reaction occurs during hydrolysis of other silicate minerals. Alternatively, rocks with a mafic to intermediate composition, similar to the Pyramid Sequence, would produce large amounts of calcium, magnesium, and bicarbonate.

Evaporation appears to have altered the two primary types of water chemistry at certain springs. Springs sampled in the southern Fort Sage Mountains have a calcium-magnesiumsulfate chemistry, which is not typical of springs that discharge from the Pyramid Sequence (fig. 9; DRI 15, 16, and 17). Springs sampled in the eastern Seven Lakes Mountain (site 27 and DRI 1) and in the northern Dogskin Mountains (site 24 and DRI 8, and 9) have a sodium-bicarbonate-sulfate chemistry, which is not typical of springs that discharge from the Hartford Hill Rhyolite. Most of these springs were dry or stagnant in March 2003, but flow resumed in April and were sampled in June 2003 by Thomas and Albright (2003). Evaporation of spring discharge would concentrate dissolved ions and, if discharge completely stopped, precipitate carbonate, sulfate, and chloride salts. When discharge resumes, the spring chemistry would change due to preferential dissolution of chloride first, then sulfate, and finally carbonate salts (Drever, 1988, p. 240). As salts are flushed out, concentrations and ratios of ions would approach the primary water chemistry. This would explain the high ratios of sulfate to bicarbonate in these samples as compared to the primary water types.

Ion ratios in ground water of the basin-fill aquifer (sites 9, 14, and 19) and in streamflow (Stantec Consulting, Inc. and Cordilleran Hydrology, 2000, p. 19) plot between the two primary water types, indicating a mixture of water (fig. 9). Springs with secondary chemistry have little to no affect on the chemistry of ground water in the basin-fill aquifer and streamflow. Ion ratios in shallow ground water near Dry Valley Creek in the center of the basin (site 19), deep ground water near the State line (site 9), and streamflow are similar to springs that discharge from the Pyramid Sequence. Ion ratios in shallow ground water near the mouth of Dry Valley (site 14) appear to be about an equal mixture of the two primary water types, indicating mixing of ground water that has moved through both the Pyramid Sequence and Hartford Hill Rhyolite. Additional ground water could be discharging along a fault or fault zone at shallow depths into the unconsolidated sediment, resulting in the mixed chemistry observed in the shallow ground water near the State line.

Chloride is a good indicator of evaporation because it behaves conservatively relative to other major ions. If evaporation is the main process affecting constituent concentrations, then there should be a positive, linear relation between chloride and dissolved-solids concentrations. This assumes that recharge is the only source of chloride and minerals do not precipitate along ground-water flow paths. Precipitation and dry fallout likely is the only source of chloride in Dry Valley because mafic rocks and rhyolite are not significant sources. If chloride salts were present in the unconsolidated sediments, then concentrations and ratios of chloride to other anions should be higher in ground water than in spring discharge.

Calcite is commonly the first salt to reach saturation and subsequently precipitate from solution. To determine if calcite could precipitate from ground water in Dry Valley, saturation indices $\left(\mathrm{SI}_{\text {calcite }}\right)$ were calculated using WATEQ4F (Ball and Nordstrom, 1991). If calcite has not reached saturation, it is unlikely that other salts have reached saturation. $\mathrm{SI}_{\text {calcite }}$ values of zero $( \pm 0.3)$ indicate that the water is at or near equilibrium and that calcite could precipitate. $\mathrm{SI}_{\text {calcite }}$ values indicate only three springs (DRI 5, 15, and 17; Thomas and Albright, 2003) and one ground-water sample (site 19) are at equilibrium with respect to calcite and the remaining samples are under saturated (table 7). Therefore, it is unlikely that significant amounts of salts are precipitating along ground-water flow paths. However, minerals likely will precipitate around spring orifices as discharge evaporates.

The relation between chloride and dissolved-solids concentrations for samples collected in Dry Valley generally is positive and linear, but exhibit different slopes for primary and secondary water chemistries (fig. 10). Springs with primary water chemistry, ground water in unconsolidated sediments, and streamflow all plot along the same trend. Sites 9, 14, 19, 25, and 27 have the highest chloride and dissolved solids concentrations (table 5). This relation and the ratios of major ions (fig. 9) indicate that ground water has evolved by evaporation of primary waters and mixing with water that is characterized by the chemistry observed at site 25 . The mean and median chloride concentration for springs with a primary water chemistry is 4.5 and 4.8 $\mathrm{mg} / \mathrm{L}$, respectively. Chloride concentrations in streamflow were 7 and $9 \mathrm{mg} / \mathrm{L}$. Chloride concentrations in deep ground water (site 9) and in the spring on the valley floor (site 25) were 10.4 and $10.8 \mathrm{mg} / \mathrm{L}$, respectively. Concentrations of chloride in shallow ground water (sites 14 and 19) are 14.8 and $19.6 \mathrm{mg} / \mathrm{L}$. If spring discharge represents recharge to the deeper ground water and streamflow infiltration recharges the shallow ground water, then about 50 percent of spring discharge and streamflow would need to evaporate to obtain the chloride concentrations that were measured in ground water.

Compared to the relation for primary water chemistries, springs that were stagnant have high chloride concentrations and springs that had ceased to flow have low concentrations for the same dissolved-solids concentrations. These differences could be due to the nature of spring discharge and flushing of salts that had accumulated around the spring orifice. Soils around springs that are stagnant are moist, indicating that evaporation is continually accumulating salts in the discharge zone even when there is no visible flow. Carbonate salts could precipitate in the diffuse discharge zone without precipitation of chloride salts, which could explain the high chloride to dissolved- solids ratio for these springs. Soils were dry around springs that ceased to flow, so all salts would have precipitated in the discharge zone. When spring discharge resumes, preferential dissolution of chloride salts could result in initially high chloride to dissolved-solids ratio for these springs. Continued 
Table 7. Saturation indices of calcite $\left(\left.S\right|_{\text {calcite }}\right)$ for ground water in Dry Valley, west-central Nevada

\begin{tabular}{|c|c|}
\hline $\begin{array}{l}\text { Site number } \\
\text { (fig. 2) }\end{array}$ & SI $_{\text {calcite }}{ }^{a}$ \\
\hline \multicolumn{2}{|c|}{ Well sites (fig. 2) } \\
\hline 9 & -0.4 \\
\hline 14 & -0.6 \\
\hline 19 & -0.1 \\
\hline \multicolumn{2}{|c|}{ Spring sites (fig. 2) } \\
\hline 24 & -3.2 \\
\hline 25 & -2.1 \\
\hline 26 & -0.4 \\
\hline 27 & -1.0 \\
\hline 28 & -0.5 \\
\hline \multicolumn{2}{|c|}{$\begin{array}{c}\text { Spring Sites } \\
\text { (Thomas and Albright, 2003, table 4) }\end{array}$} \\
\hline DRI-1 & -2.4 \\
\hline DRI-2 & -0.8 \\
\hline DRI-3 & -0.4 \\
\hline DRI-4 & -0.6 \\
\hline DRI-5 & 0.2 \\
\hline DRI-6 & -2.8 \\
\hline DRI-7 & -0.4 \\
\hline DRI-8 & -2.2 \\
\hline DRI-9 & -3.2 \\
\hline DRI-10 & -1.3 \\
\hline DRI-11 & -2.4 \\
\hline DRI-12 & -1.3 \\
\hline DRI-13 & -1.6 \\
\hline DRI-14 & -1.4 \\
\hline DRI-15 & -0.2 \\
\hline DRI-16 & -0.9 \\
\hline DRI-17 & -0.2 \\
\hline DRI-18 & -1.6 \\
\hline DRI-19 & -2.1 \\
\hline DRI-20 & -2.2 \\
\hline DRI-21 & -2.1 \\
\hline
\end{tabular}

${ }^{\mathrm{a} S a t u r a t i o n}$ index $=\log [$ Activity product $] / \mathrm{K}_{T \text { - }}$ where $\mathrm{K}_{T}=$ equilibrium constant at temperature $T$. By convention, a positive value indicates a mineral can precipitate from solution, and a negative value indicates a mineral can dissolve if present.

discharge would flush the chloride salts from the discharge zone resulting in low chloride to dissolved-solids ratios for springs that had been previously dry.

Stable isotopes of oxygen and hydrogen of water are useful in determining if different sources of water are hydraulically connected and if water has evaporated. The stable isotopes evaluated were oxygen-18 relative to oxygen- $16\left({ }^{18} \mathrm{O} /{ }^{16} \mathrm{O}\right)$ and deuterium (hydrogen-2) relative to hydrogen- $1\left({ }^{2} \mathrm{H} /{ }^{1} \mathrm{H}\right)$. Each ratio is determined for a sampled water and then related mathemati- cally to the comparable ratio for an international reference standard known as Vienna-Standard Mean Ocean Water (V-SMOW; Fritz and Fontes, 1980). By convention, the computed results are expressed as delta oxygen-18 $\left(\delta^{18} \mathrm{O}\right)$ and delta deuterium $(\delta \mathrm{D})$ in parts per thousand (abbreviated "permil" or $\% o$ ). The delta notation is computed from the equation:

$$
\delta=\left[\left(\mathrm{R}_{\mathrm{x}}-\mathrm{R}_{\mathrm{std}}\right) / \mathrm{R}_{\mathrm{std}}\right] * 1,000
$$

where $\delta$ is the delta notation of $\delta^{18} \mathrm{O}$ or $\delta \mathrm{D}$;

$$
\begin{aligned}
& \mathrm{R}_{\mathrm{x}} \text { is the ratio of }{ }^{18} \mathrm{O} /{ }^{16} \mathrm{O} \text { or }{ }^{2} \mathrm{H} /{ }^{1} \mathrm{H} \text { measured in sample; } \\
& \mathrm{R}_{\text {std }} \text { is the ratio of }{ }^{18} \mathrm{O} /{ }^{16} \mathrm{O} \text { or }{ }^{2} \mathrm{H} /{ }^{1} \mathrm{H} \text { in standard. }
\end{aligned}
$$

Water that is enriched in lighter isotopes $\left({ }^{1} \mathrm{H}\right.$ and $\left.{ }^{16} \mathrm{O}\right)$ relative to $\mathrm{V}-\mathrm{SMOW}$ has negative values. Evaporation and condensation are the most significant processes that change delta values. Variations in ${ }^{18} \mathrm{O} /{ }^{16} \mathrm{O}$ and ${ }^{2} \mathrm{H} /{ }^{1} \mathrm{H}$ in ground water reflect differences in latitude, altitude, and seasonal variations, which are factors that affect recharge temperature. The ratios of these isotopes are virtually unaffected by low-temperature geochemical processes in ground water (Muir and Coplen, 1981), such as in Dry Valley.

Springs and ground water are part of the same flow system in Dry Valley indicated by linear related $\delta \mathrm{D}$ and $\delta^{18} \mathrm{O}$ values (fig. 11). In general, high altitude springs have the most negative values and ground water from the unconsolidated sediments has the least negative values. The slope of $\delta \mathrm{D} \%$ o versus $\delta^{18} \mathrm{O} \%$ in ground water and springs in Dry Valley is $4.2 \mathrm{com}$ pared to a slope of 8 for global meteoric water (Craig, 1961; fig. 11). In contrast, $\delta \mathrm{D} \%$ o versus $\delta^{18} \mathrm{O} \%$ in ground water from Spanish Springs Valley plots nearly parallel to the global meteoric water line (Berger and others, 1997, p. 34; Seiler, 1999). A slope between 3 and 6 is characteristic of evaporation from surface water (Coplen and others, 2000, p. 87), indicating springs and ground water in Dry Valley are similar to surfacewater than a typical ground-water system.

Isotopes and concentrations of major ions and their ratios indicate that a large volume of water is evaporated along ground-water flow paths in Dry Valley. Evapotranspiration of ground water by phreatophytic vegetation was estimated to be about 640 to $790 \mathrm{acre}-\mathrm{ft} / \mathrm{yr}$, which is a small fraction of the total precipitation that falls in Dry Valley and could not explain the chemistry indicating evaporation throughout the basin. Most of the springs in Dry Valley discharge from bedrock areas in the surrounding mountain blocks. The amount of subsurface discharge directly from bedrock areas to the basin-fill aquifer is unknown, but the chloride concentration and isotopes from deep ground water suggest it is small. It is possible that much of the spring discharge evaporates before it recharges the basin-fill aquifer. If evaporation of spring discharge is significant before it recharges the basin-fill aquifer, then using chemistry data from springs would overestimate ground-water recharge. 


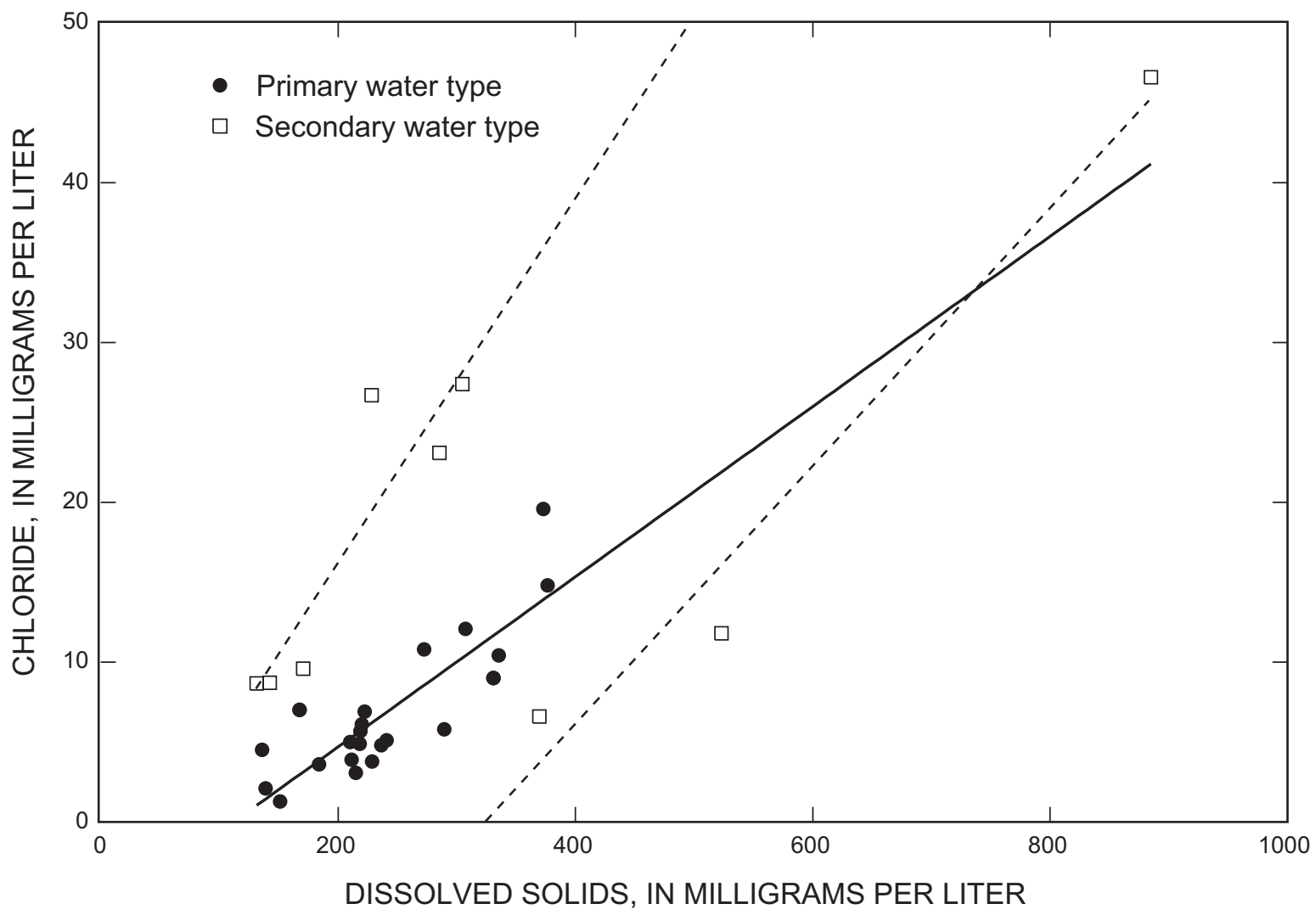

Figure 10. Chloride as a function of dissolved-solids concentration, Dry Valley, west-central Nevada.

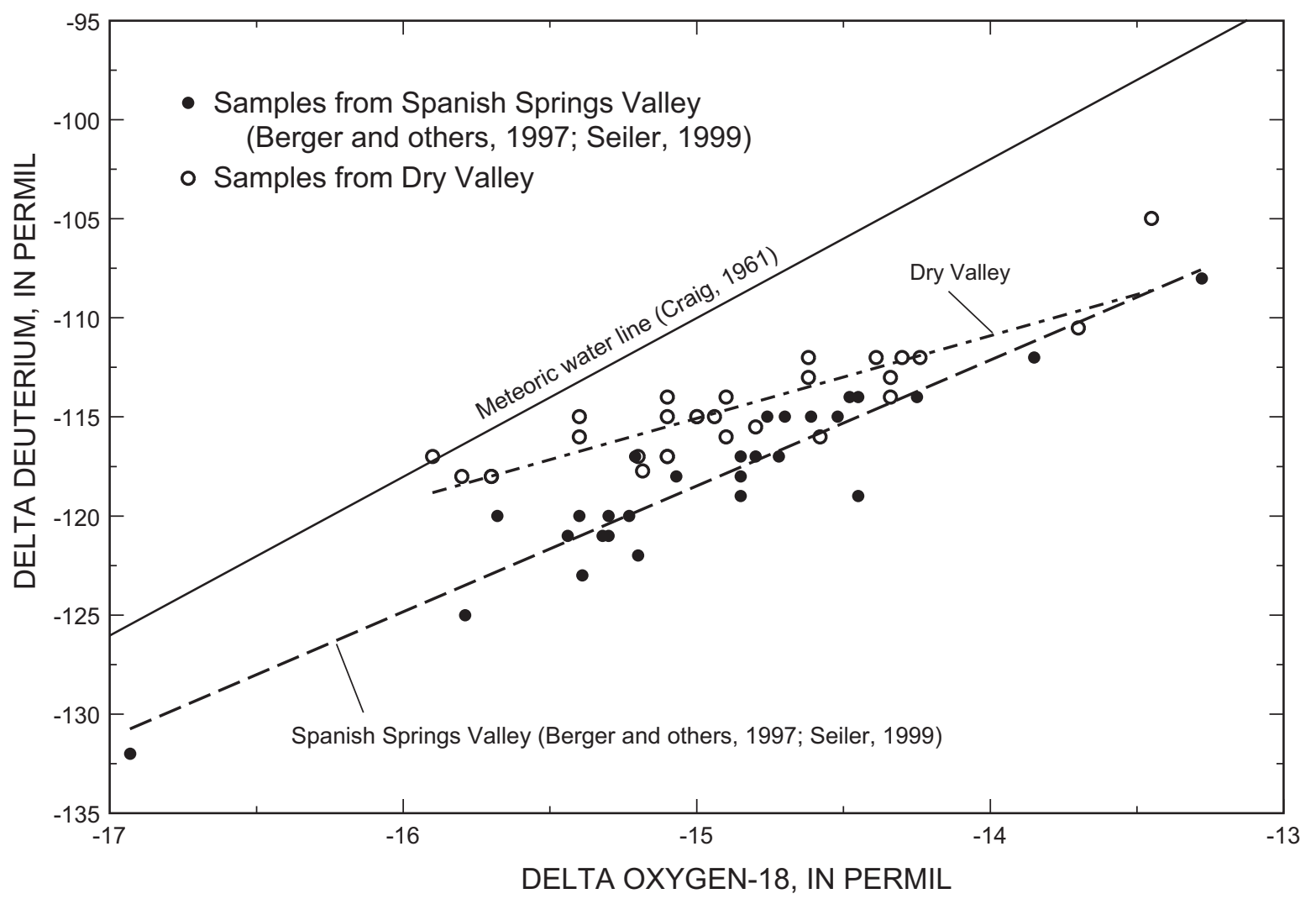

Figure 11. Relation of deuterium to oxygen-18 in sampled ground water and springs in Dry Valley, west-central Nevada. 


\section{Summary}

The Dry Valley Hydrographic Area is being considered as a source area for additional water supplies for the Reno-Sparks area, which is about $25 \mathrm{mi}$ to the south of Dry Valley. Current estimates of annual ground-water recharge to Dry Valley have a considerable range and are a direct function of the particular precipitation data used in the recharge estimate. Because estimating ground-water discharge has more certainty than estimating ground-water recharge from precipitation, the USGS, in cooperation with Washoe County, began a three-year study to re-evaluate the ground-water resources in Dry Valley, with emphasis on estimating natural ground-water discharge.

The boundary of the Dry Valley Hydrographic Area encompasses about $82 \mathrm{mi}^{2}$ in Washoe County, Nev. and about $3 \mathrm{mi}^{2}$ in Lassen County, Calif. Dry Valley is topographically open to the west and is bounded on the north, east, south by fault-controlled mountain blocks. The Nevada-California State line was chosen as the western boundary of the study area to provide a practical location for estimating ground-water outflow. Dry Valley Creek, which drains the entire area of Dry Valley, flows across the western boundary and is tributary to Long Valley Creek in California.

Phreatophytic vegetation on the valley floor consists of saltgrass with small isolated stands of greasewood, rabbitbrush, and big sagebrush. Based on field mapping and satellite imagery acquired on July 8, 2002, phreatophytic vegetation covers about 620 acres. Areas of bare soil, where ground-water ET takes place from the shallow water table, covers about 1,500 acres. Riparian type vegetation found along stream channels and near springs and ground-water seeps includes cottonwood trees, willows, and a variety of shrubs and grasses.

Dry Valley is near the intersection of the northwest-trending strike-slip Walker Lane fault zone and the north-trending normal-type Sierra Nevada frontal fault zone. Northwest trending strike-slip faults are mapped near the mouth of Dry Valley on the western side and along a zone through the center of Dry Valley. Movement along these faults also is vertical, producing the uplift of Dogskin Mountain. In unconsolidated sediments, faults usually are barriers to ground-water, whereas the effect of faulting on ground-water flow in consolidated rocks is variable and difficult to predict without water-level data near the fault.

The mountain blocks surrounding Dry Valley are composed of granitic rocks of pre-Cenozoic age, overlain by two volcanic rock units of Tertiary age. Granitic rocks make up the bulk of the Sierra Nevada west of Dry Valley. Near Dry Valley they are exposed near the center of Fort Sage Mountain, on the southern part of Dogskin Mountain, and on the western flank of Seven Lakes Mountain. The granitic rocks likely are thousands of feet thick and form a relatively impermeable basement to ground-water flow.

The oldest volcanic rocks overlying the granitic rocks are welded to non-welded rhyolitic tuffs of early to middle Miocene age, mapped as the Hartford Hill Rhyolite. The maximum thickness of the tuffs is about $4,000 \mathrm{ft}$ and they may extend into the subsurface beneath Long Valley and western Dry Valley. Near the mouth of Dry Valley, the tuffs appear to be largely nonwelded and may include tuffaceous-sedimentary deposits. Where welded, the tuffs may be capable of transmitting ground water. Where non-welded, the tuffs and tuffaceous-sedimentary deposits are likely relatively impermeable.

Overlying the rhyolitic tuffs is a complex mixture of basalt, basaltic andesite, andesite flows, and flow breccias, interbedded with sedimentary rocks of diatomite and shale, rhyolitic tuffs and tuff breccias, and dacite welded tuffs. These rocks are informally assigned to the Pyramid Sequence of late Miocene age. They cover large areas of the Virginia Mountains and are exposed on the southern and northern flanks of the Fort Sage and Seven Lakes Mountains, respectively. The thickness of the unit may range from 2,000 to $3,000 \mathrm{ft}$.

Unconsolidated sediments beneath and along the margins of the floor of Dry Valley HA consist of stream and alluvial fan deposits of Quaternary age and deposits derived from Pleistocene Lake Lahontan. High stands of Lake Lahontan extended about $2.7 \mathrm{mi}$ east of the State line into the mouth of Dry Valley. As the levels of Lake Lahontan rose and fell, deposition near the western side of Dry Valley alternated between fine-grained silts and clay during high stands, and coarse-grained beach and stream deposits during low stands, producing poorly sorted sediments.

Geophysical logs collected from boreholes of wells installed near the State line show sand and gravel layers alternating with clay throughout the upper 200 to $250 \mathrm{ft}$ of the boreholes. Below that depth, sediments become progressively more clayey with a sand and gravel layer about $20 \mathrm{ft}$ thick near $400 \mathrm{ft}$, and relatively thin stringers of sand near 490 and $510 \mathrm{ft}$. Below that depth, sediments are mostly clay. Seismic-refraction data show velocities typical of unsaturated and saturated unconsolidated sediments 2,500 to $6,600 \mathrm{ft} / \mathrm{s}$ to a depth of about $200 \mathrm{ft}$ below land surface. Beneath $200 \mathrm{ft}$, velocities are about $8,000 \mathrm{ft} / \mathrm{s}$, more typical of saturated semi-consolidated sediments. The aquifer materials likely are poorly permeable at depths more than 200-250 ft beneath the floor of Dry Valley.

Streamflow observations and miscellaneous discharge measurements collected from Dry Valley Creek, about one mile west of the State line, indicate a maximum of about 210 acre- $\mathrm{ft}$ of surface water outflow from Dry Valley in the 2003 water year. Precipitation in the region during the 2003 water year was about 78 percent of the long-term average, which may account for the low streamflow from Dry Valley. Rush and Glancy (1967, p. 30), suggest that the long-term average annual streamflow exiting Dry Valley at the State line is 4,000 acre-ft/yr.

Water levels in wells on the floor of Dry Valley confirm that ground-water flow is toward the west. The water-table gradient near the State line changes from $0.003 \mathrm{ft} / \mathrm{ft}$ east of the State line to $0.005 \mathrm{ft} / \mathrm{ft}$ west of the State line. The change in gradient across the State line may be caused by the combination of less permeable lake deposits to the west and restriction of ground-water flow through the narrow width of unconsolidated sediments west of the State line. The non-welded rhyolitic tuffs 
on the northern and southern sides of the unconsolidated sediments are poorly permeable and produce a damming effect on ground-water upgradient from the State line.

Ground-water flow from the upper part of Dry Valley to Winnemucca Valley likely is not significant based on similar altitudes for phreatophytes in each valley. Ground-water outflow from the upper part of Dry Valley to Honey Lake near the California-Nevada State line is not likely because of a lack of springs in that part of Honey Lake Valley.

Analysis of two aquifer tests show the transmissivity of poorly sorted sediments near the western side of Dry Valley is 1,200 to $1,500 \mathrm{ft}^{2} /$ day. The width of unconsolidated sediments ranges from 1,500 to 4,000 ft near the State line. The hydraulic gradient east and west of the State line ranges from 0.003 to 0.005. Using these values with Darcy's Law, estimates of subsurface outflow to Long Valley ranges from 50 to 250 acre-ft/yr.

About 640 to 790 acre-ft/yr of ground water is lost to evapotranspiration in Dry Valley. Combining subsurface-outflow estimates with ground-water evapotranspiration estimates, total natural ground-water discharge from Dry Valley ranges from a minimum of 700 acre- $\mathrm{ft}$ to a maximum of 1,000 acre- $\mathrm{ft}$ annually.

Water quality in Dry Valley generally is good and primary drinking-water standards were not exceeded in any samples collected. The secondary standard for manganese was exceeded in three ground-water samples. One spring sample and two surface-water samples were outside the range for the secondary standard for $\mathrm{pH}$. Dry Valley has two primary types of water chemistry that are distinguishable by cation ratios and related to the two volcanic units that make up much of the surrounding mountains. In addition, two secondary types of water chemistry appear to have evolved by evaporation of the primary water types. Ground water near the State line appears to be almost an equal mixture of the two primary water chemistries and has as an isotopic characteristic similar to evaporated surface water.

\section{References Cited}

Adar, E.M., Neuman, S.P., and Woolhiser, D.A., 1988, Estimation of spatial recharge distribution using environmental isotopes and hydrochemical data, 1. Mathematical model and application to synthetic data: Journal of Hydrology, 97, p. 251-277.

Antonellini, Marco, Aydin, Atilla, and Orr, Lynn, 1999, Outcrop-aided characterization of a faulted hydrocarbon reservoir: Arroyo Grande Oil Field, California, USA, in Haneberg, W.C., Mozley, P.S., Moore, J.C., and Goodwin, L.B., eds., Faults and subsurface fluid flow in the shallow crust, Geophysical Monograph 113, American Geophysical Union, Washington, D.C., 222 p.
Ball, J.W., and Nordstrom, D.K., 1991, User's manual for WATEQ4F, with revised thermodynamic data base and test cases for calculating speciation of major, trace, and redox elements in natural waters: U.S. Geological Survey OpenFile Report 91-183, 189 p. (Revised and reprinted August 1992).

Bell, J.W., 1984, Quaternary fault map of Nevada of the 1-degree by 2-degree Reno quadrangle, [Nevada]: U.S. Geological Survey Open-File Report 81-982, 62 p.

Barthelmes, A.J., 1946, Application of continuous profiling to refraction shooting: Geophysics, v. 11, no. 1, p. 24-42.

Benson, L.V., and Thompson, R.S., 1987, Lake-level variation in the Lahontan Basin for the past 50,000 years: Quaternary Research, v. 28, p. 69-85.

Berger, D.L., Ponce, D.A., and Ross, W.C., 2001, Hydrogeologic framework of Antelope Valley and Bedell Flat, Washoe County, west-central Nevada: U.S. Geological Survey Water-Resources Investigation Report 01-4220, 11 p.

Berger, D.L., Ross, W.C., Thodal, C.E., and Robledo, A.R., 1997, Hydrogeology and simulated effects of urban development on water resources of Spanish Springs Valley, Washoe County, west-central Nevada: U.S. Geological Survey Water-Resources Investigation Report 96-4297, 80 p.

Bonham, H.F., 1969, Geology and mineral deposits of Washoe and Story Counties Nevada: Nevada Bureau of Mines and Geology Bulletin 70, 140 p.

Brenner, I.S., 1974, A surge of maritime tropical air-Gulf of California to the southwestern United States: Monthly Weather Review, v. 102, p. 375-389.

Caine, J.S., and Forster, C.B., 1999, Fault zone architecture and fluid flow-Insights from field data and numerical modeling, in Haneberg, W.C., Mozley, P.S., Moore, J.C., and Goodwin, L.B., eds., Faults and subsurface fluid flow in the shallow crust: American Geophysical Union Monograph, v. 113, p. 101-127.

Cardinalli, J.L., Roach, L.M., Rush, F.E., and Vasey, F.J., comps., 1968, State of Nevada hydrographic areas: Nevada Division of Water Resources Bulletin 33, 162 p.

Cooper, H.H., and Jacob, C.E., 1946, A generalized graphical method for evaluating formation constants and summarizing well field theory: American Geophysical Union Transactions, v. 27, p. 526-534.

Coplen, T.B., Herczeg, A.L., and Barnes, Chris, 2000, Isotope engineering-Using stable isotopes of the water molecule to solve practical problems: in Environmental Tracers in Subsurface Hydrology, Cook, P., and Herczeg, A.L., eds., Boston, Kluwer Academic Publishers, 529 p.

Craig, H., 1961, Isotopic variations in natural water: Science, v. 133, p. 1702-1703.

Daly, Christopher, Neilson, R.P., and Phillips, D.L., 1994, A statistical topographic model for mapping climatological precipitation over mountainous terrain: Journal of Applied Meteorology, v. 33, p. 140-158. 
Dettinger, M.D., 1989, Reconnaissance estimates of natural recharge to desert basins in Nevada, U.S.A., by using chloride-balance calculations: Journal of Hydrology, v. 106, p. 55-78.

Nevada State Engineer, 2003, Title 48-Water: Nevada Division of Water Resources, Nevada Water Laws, chap. 232, NRS 232.005, 232.010 through 232.150.

Dobrin, M.R., 1976, Introduction to geophysical prospecting: New York, McGraw-Hill Inc. 630 p.

Drever, J.I., 1988, The geochemistry of natural water: Prentice Hall, Inc., New Jersey, 437 p.

Fritz, Peter, and Fontes, Jean-Charles, eds., 1980, Handbook of environmental isotope geochemistry, v. 1: Amsterdam, Elsevier Scientific Publishing Company, 545 p.

Gill, P.E., Murray W., and Wright, M.H., 1981, Practical Optimization, Academic Press, San Diego, Calif., 401 p.

Goodwin, L.B., Mozley, P.S., Moore, J.C., and Haneberg, W.C., 1999, Introduction, in Hanneberg, W.C., Mozley, J.C., and Goodwin, L.B., eds., Faults and subsurface fluid flow in the shallow crust, Geophysical Monograph 113, American Geophysical Union, Washington, D.C., 222 p.

Grose, T.L.T., and Merger, M., 2000, Geologic map of the Chilcoot 15 minute quadrangle, Lassen and Plumas Counties, California: California Division of Mines and Geology OpenFile Report 2000-23, scale, 1:62,500.

Handman, E.H., Longquist, C.J., and Maurer, D.K., 1990, Ground-water resources of Honey Lake Valley, Lassen County, California, and Washoe County, Nevada: U.S. Geological Survey Water-Resources Investigation Report 90-4050, 112 p.

Harbaugh, A.W., and McDonald, M.G., 1996, Programmer's documentation for MODFLOW-96, an update to the U.S. Geological Survey modular finite-difference ground-water flow model: U.S. Geological Survey Open-File Report 96-486, $220 \mathrm{p}$.

Hardman, George, 1936, Nevada precipitation and acreages of land by rainfall zones: University of Nevada, Reno Agricultural Experiment Station mimeographed report, 10 p. and map.

Hardman, George, 1965, Nevada precipitation map: Nevada Division of Conservation and Natural Resources Report, $27 \mathrm{p}$.

Heath, R.C., 1989, Basic ground-water hydrology: U.S. Geological Survey Water-Supply Paper 2220, 84 p.

Healy, J.H. and Press, Frank, 1964, Geophysical studies of basin structures along the eastern front of the Sierra Nevada, California: Geophysics, v. 24, no. 3, p. 337-359

Hem, J.D., 1985, Study and interpretation of the chemical characteristics of natural water: U.S. Geological Survey Water-Supply Paper 2254, 263 p.

Henry, C.D., Faulds, J.E., de Polo, C.M., and Davis, D.A., 2002, Preliminary geologic map of the Dogskin quadrangle, Washoe County, Nevada: Nevada Bureau of Mines and Geology, Open-File Report 03-16, 1-map sheet, 1:24,000.
Heynekamp, M.R., Goodwin, L.B., Mozley, P.S., and Haneberg, W.C., 1999, Controls on fault-zone architecture in poorly lithified sediments, Rio Grande Rift, New Mexico: implications for fault-zone permeability and fluid flow, in Haneberg, W.C., Mozley, P.S., Moore, J.C., and Goodwin, L.B., eds., Faults and subsurface fluid flow in the shallow crust: American Geophysical Union Monograph 113, American Geophysical Union, Washington D.C., 222 p.

Houghton, J.G., 1969, Characteristics of rainfall in the Great Basin: University of Nevada, Desert Research Institute Report, 205 p.

Hurlbert, C.S. Jr., and Klein, Cornelis, 1977, Manual of mineralogy (19th ed.): John Wiley and Sons, New York, 532 p.

Keys, W.S., 1990, Borehole geophysics applied to groundwater investigations: U.S. Geological Survey Techniques of Water-Resources Investigations, Book 2, Chap. E2, 150 p.

Maxey, G.B., and Eakin, T.E., 1949, Ground water in White River Valley, White Pine, Nye, and Lincoln Counties Nevada: Nevada State Engineer, Water-Resources Bulletin $8,59 \mathrm{p}$.

McDonald, M.G., and Harbaugh, A.W., 1988, A modular threedimensional finite-difference ground-water flow model: U.S. Geological Survey Techniques of Water-Resources Investigations, book 6, chap. A1, $576 \mathrm{p}$.

Meinzer, O.E., 1927, Plants as indicators of ground water: U.S. Geological Survey Water-Supply Paper 577, 586 p.

Muir, K.S., and Coplan, T.B., 1981, Tracing ground-water movement by using the stable isotopes of oxygen and hydrogen, Upper Penitencia Creek alluvial fan, Santa Clara Valley, California: U.S. Geological Survey Water-Supply Paper 2075, 18 p.

Nelson, E.P., Kullman, A.J., Gardner, M.H., and Batzle, Michael, 1999, Fault-fracture networks and related fluid flow and sealing, Brushy Canyon Formation, west Texas, in Haneberg, W.C., Mozley, P.S., Moore, J.C., and Goodwin, L.B., eds., Faults and subsurface fluid flow in the shallow crust, Geophysical Monograph 113, American Geophysical Union, Washington, D.C., 222 p.

Nevada State Engineer, 1974, Water-Legal and administrative aspects: Nevada Division of Water Resources, Water for Nevada Special Information Report, 60 p.

Nichols, W.D., 2000, Regional ground-water evapotranspiration and ground-water budgets, Great Basin, Nevada: U.S. Geological Survey Professional Paper 1628, 82 p.

Pakiser, L.C., and Black, R.A., 1957, Exploring for ancient channels with the refraction seismograph: Geophysics, v. 22, no. 1, p. 32-47.

Reheis, M.C., Sarna-Wojciki, A.M., Reynolds, R.L., Repenning, C.A., and Mifflin, M.D., 2002, Pliocene to middle Pleistocene lakes in the western Great Basin: ages and connections, in Hershler, R., Curry, D., and eds., Great Basin aquatic systems history: Washington D.C., Smithsonian Institution, Smithsonian contributions to the earth sciences, p. 53-108. 
Ritter, D.F., 1982, Process geomorphology: Southern Illinois University at Carbondale, Wm. C. Brown, Dubuque, Iowa, $603 \mathrm{p}$.

Rush, F.E., 1968, Index of hydrographic areas: Nevada Division of Water Resources, Information Report 6, 38 p.

Rush, F.E., and Glancy, P.A., 1967, Water-resources appraisal of the Warm Springs-Lemmon Valley area, Washoe County, Nevada: Nevada Department of Conservation and Natural Resources, Water Resources-Reconnaissance Report 43, $70 \mathrm{p}$.

Scott, J.H., 1993, SIPT2-A personal computer program for interpreting seismic refraction data using modeling and iterative ray tracing techniques: Rimrock Geophysics, Inc. $12 \mathrm{p}$.

Seiler, R.L., 1999, A chemical signature for ground water contaminated by domestic wastewater: University of Nevada, Reno, Department of Environmental Sciences and Health, Ph. D. dissertation, $125 \mathrm{p}$.

Stantec Consulting Inc. and Cordilleran Hydrology, 2000, Hydrogeology of Dry Valley, Washoe County, Nevada: prepared for Intermountain Pipeline, Ltd., Reno, Nevada, Project No. 80200124, 27 p.

Stewart, J.H., 1980, Geology of Nevada-Discussion to accompany the geologic map of Nevada: Nevada Bureau of Mines and Geology Special Publication 4, 136 p.
Theis, C.V., 1940, The sources of water derived from wells: Civil Engineering, May 1940, v. 10, no. 5, p. 277-280.

Thomas, J.T., and Albright, W.H., 2003, Estimated recharge to Dry Valley, northeastern Nevada using the chloride mass balance method: Desert Research Institute Publication no. 41191,25 p.

U.S. Geological Survey, 2003, Quaternary fault and fold database of the United States: U.S. Geological Survey Open-File Report 03-417: accessed April 20, 2004 at URL $<$ http://qfaults.cr.usgs.gov/index.htm>.

Watson, Phil, Sinclair, Peter, Waggoner, Ray, 1975, Quantitative evaluation of a method for estimating recharge to the desert basins of Nevada: Journal of Hydrology, 31, p. 335-357.

Western Regional Climate Center, 2003, Western U.S. climate historical summaries: Desert Research Institute, accessed March 1, 2004, at URL <http://www.wrcc.sage.dri.edu/>. Accessed November 2004 at URL $<$ http://www.wrcc.dri.edu/CLIMATEDATA.html>.

Wilde, F.D., Radtke, D.B., Gibs, Jacob, and Iwatsubo, R.T., 1999, Collection of water samples: Chapter A4 in National Field Manual for the collection of water-quality data, Techniques of Water-Resources Investigations Book 9.

Zohdy, A.A., Eaton, G.P., and Mabey, D.R., 1974, Application of surface geophysics to ground-water investigations: U.S. Geological Survey Techniques of Water-Resources Investigations, book 2, chap. D1, $116 \mathrm{p}$. 


\section{Appendix - Selected ground-water levels measured in wells, Dry Valley, west-central Nevada}


Appendix-Selected ground-water levels measured in wells, Dry Valley, west-central Nevada

Site number is a short identification number in this report.

Each U.S. Geological Survey data-collection site is assigned a unique identification on the basis of geographic location. Wells and springs are identified by a local system (Nevada and California) and a standard latitude-longitude system. For convenience, short site number (1 - 28) also are used for sites discussed in this report. In California wells are numbered according to their location in the rectangular system for subdivision of public lands. Identification consists of the township number, north or south (N or $\mathrm{S}$ ); the range number, east or west (E or W); and the section number. Each section is divided into sixteen 40-acre tracts lettered consecutively (except I and O) beginning with "A" in the northeast corner of the section and progressing in a sinusoidal manner to "R" in the southeast corner. Within the 40-acre tract, wells are sequentially numbered in the order they are inventoried. The final letter (M) refers to the Mount Diablo base line and meridian. In Nevada, a local site designation is used to identify a site by hydrographic area (Rush, 1968) and by the official rectangular subdivision of the public lands referenced to the Mount Diablo base line and meridian. Each site designation consists of four units. The first unit is the hydrographic area number. The second unit is the township, preceded by $\mathrm{N}$ to indicate location north of the base line. The third unit is the range, preceded by " $E$ " to indicate location east of the meridian. The fourth unit consists of the section number and letters designating the quarter section, quarter-quarter section and so on (A, B, C, and D indicate the northeast, northwest, southwest, and southeast quarter, respectively), followed by a number indicating the sequence in which the site was recorded.

The standard identification is based on the grid system of latitude and longitude. The number consists of 15 digits. The first six digits denote the degrees, minutes, and seconds of latitude; the next seven digits denote the degrees, minutes, and seconds of longitude; and the last two digits (assigned sequentially) identify the sites within a 1-second grid. The assigned number is retained as a permanent identifier even if a more precise latitude and longitude are later determined.

Measurement method: S, steel tape; T, electric tape.

\begin{tabular}{|c|c|c|c|c|c|}
\hline $\begin{array}{c}\text { Site } \\
\text { number } \\
\text { (fig. 2) }\end{array}$ & Local identification & Standard identification & $\begin{array}{c}\text { Water-level } \\
\text { date }\end{array}$ & $\begin{array}{c}\text { Water level } \\
\text { below } \\
\text { land surface }\end{array}$ & $\begin{array}{l}\text { Measurement } \\
\text { method }\end{array}$ \\
\hline \multirow[t]{9}{*}{1} & \multirow[t]{9}{*}{ 024N018E06H01M } & \multirow[t]{9}{*}{395832119595901} & $02 / 06 / 2002$ & 116.57 & $\mathrm{~T}$ \\
\hline & & & $08 / 21 / 2002$ & 116.51 & $\mathrm{~T}$ \\
\hline & & & $01 / 07 / 2003$ & 116.55 & $\mathrm{~T}$ \\
\hline & & & $03 / 06 / 2003$ & 116.55 & $\mathrm{~T}$ \\
\hline & & & $05 / 05 / 2003$ & 117.89 & $\mathrm{~S}$ \\
\hline & & & $06 / 19 / 2003$ & 118.07 & $\mathrm{~S}$ \\
\hline & & & $08 / 14 / 2003$ & 116.55 & $\mathrm{~T}$ \\
\hline & & & $11 / 20 / 2003$ & 113.40 & $\mathrm{~T}$ \\
\hline & & & $01 / 30 / 2004$ & 114.23 & $\mathrm{~T}$ \\
\hline \multirow[t]{9}{*}{2} & \multirow[t]{9}{*}{ 024N018E07D01M } & \multirow[t]{9}{*}{395748120004601} & $02 / 12 / 2002$ & 6.94 & $\mathrm{~T}$ \\
\hline & & & $08 / 21 / 2002$ & 7.41 & $\mathrm{~T}$ \\
\hline & & & $01 / 07 / 2003$ & 6.77 & $\mathrm{~T}$ \\
\hline & & & $03 / 06 / 2003$ & 6.89 & $\mathrm{~T}$ \\
\hline & & & $05 / 05 / 2003$ & 6.86 & $\mathrm{~S}$ \\
\hline & & & $06 / 19 / 2003$ & 7.12 & $\mathrm{~S}$ \\
\hline & & & $08 / 14 / 2003$ & 7.61 & $\mathrm{~T}$ \\
\hline & & & $11 / 20 / 2003$ & 7.28 & $\mathrm{~T}$ \\
\hline & & & $01 / 30 / 2004$ & 7.12 & $\mathrm{~T}$ \\
\hline \multirow[t]{10}{*}{3} & \multirow[t]{10}{*}{095 N24 E18 07ADAB1 } & \multirow[t]{10}{*}{395747119595401} & $11 / 13 / 2002$ & 9.00 & $\mathrm{R}$ \\
\hline & & & $11 / 19 / 2002$ & 6.11 & $\mathrm{~T}$ \\
\hline & & & $12 / 19 / 2002$ & 3.23 & $\mathrm{~T}$ \\
\hline & & & $12 / 23 / 2002$ & 3.20 & $\mathrm{~T}$ \\
\hline & & & $12 / 30 / 2002$ & 3.12 & $\mathrm{~T}$ \\
\hline & & & $01 / 07 / 2003$ & 2.95 & $\mathrm{~T}$ \\
\hline & & & $01 / 21 / 2003$ & 2.80 & $\mathrm{~T}$ \\
\hline & & & $01 / 22 / 2003$ & 2.80 & $\mathrm{~T}$ \\
\hline & & & $01 / 22 / 2003$ & 2.81 & $\mathrm{~T}$ \\
\hline & & & $01 / 23 / 2003$ & 2.81 & $\mathrm{~T}$ \\
\hline
\end{tabular}


Appendix-Selected ground-water levels measured in wells, Dry Valley, west-central Nevada--Continued

\begin{tabular}{|c|c|c|c|c|c|}
\hline $\begin{array}{c}\text { Site } \\
\text { number } \\
\text { (fig. 2) }\end{array}$ & Local identification & Standard identification & $\begin{array}{c}\text { Water-level } \\
\text { date }\end{array}$ & $\begin{array}{c}\text { Water level } \\
\text { below } \\
\text { land surface }\end{array}$ & $\begin{array}{l}\text { Measurement } \\
\text { method }\end{array}$ \\
\hline & & & $02 / 12 / 2003$ & 2.65 & $\mathrm{~T}$ \\
\hline & & & 03/06/2003 & 2.56 & $\mathrm{~T}$ \\
\hline & & & $03 / 28 / 2003$ & 2.52 & $\mathrm{~T}$ \\
\hline & & & $05 / 01 / 2003$ & 2.50 & $\mathrm{~T}$ \\
\hline & & & $05 / 01 / 2003$ & 2.51 & $\mathrm{~T}$ \\
\hline & & & $05 / 14 / 2003$ & 2.63 & $\mathrm{~T}$ \\
\hline & & & $06 / 19 / 2003$ & 2.95 & $\mathrm{~S}$ \\
\hline & & & $07 / 01 / 2003$ & 3.08 & $\mathrm{~T}$ \\
\hline & & & $07 / 08 / 2003$ & 3.20 & $\mathrm{~T}$ \\
\hline & & & $08 / 14 / 2003$ & 3.74 & $\mathrm{~T}$ \\
\hline & & & $11 / 20 / 2003$ & 3.91 & $\mathrm{~T}$ \\
\hline & & & $01 / 30 / 2004$ & 3.57 & $\mathrm{~T}$ \\
\hline \multirow[t]{10}{*}{4} & 095 N24 E18 09BCBD1 & 395743119582401 & $10 / 05 / 1980$ & 30. & $\mathrm{R}$ \\
\hline & & & $08 / 21 / 2002$ & 37.81 & $\mathrm{~S}$ \\
\hline & & & $11 / 19 / 2002$ & 37.71 & $\mathrm{~T}$ \\
\hline & & & $01 / 22 / 2003$ & 37.77 & $\mathrm{~T}$ \\
\hline & & & 03/06/2003 & 37.75 & $\mathrm{~T}$ \\
\hline & & & $05 / 05 / 2003$ & 37.49 & $\mathrm{~S}$ \\
\hline & & & $06 / 19 / 2003$ & 37.28 & $\mathrm{~S}$ \\
\hline & & & $08 / 14 / 2003$ & 37.47 & $\mathrm{~T}$ \\
\hline & & & $11 / 20 / 2003$ & 37.63 & $\mathrm{~T}$ \\
\hline & & & $01 / 30 / 2004$ & 37.79 & $\mathrm{~T}$ \\
\hline \multirow[t]{7}{*}{5} & 024N017E01F01M & 395740120012601 & $03 / 06 / 2003$ & 16.02 & $\mathrm{~S}$ \\
\hline & & & $03 / 28 / 2003$ & 15.94 & $\mathrm{~S}$ \\
\hline & & & $05 / 05 / 2003$ & 16.01 & $\mathrm{~S}$ \\
\hline & & & $06 / 19 / 2003$ & 15.90 & $\mathrm{~S}$ \\
\hline & & & 08/14/2003 & 16.43 & $\mathrm{~S}$ \\
\hline & & & $11 / 20 / 2003$ & 16.84 & $S$ \\
\hline & & & $01 / 30 / 2004$ & 16.78 & $\mathrm{~S}$ \\
\hline \multirow[t]{15}{*}{6} & 095 N24 E18 08ACCC1 & 395739119591401 & $10 / 21 / 2002$ & 7.85 & $\mathrm{~T}$ \\
\hline & & & $11 / 19 / 2002$ & 7.39 & $\mathrm{~T}$ \\
\hline & & & $01 / 07 / 2003$ & 6.39 & $\mathrm{~T}$ \\
\hline & & & $01 / 21 / 2003$ & 6.12 & $\mathrm{~T}$ \\
\hline & & & $01 / 22 / 2003$ & 6.11 & $\mathrm{~T}$ \\
\hline & & & $02 / 12 / 2003$ & 5.92 & $\mathrm{~T}$ \\
\hline & & & $03 / 06 / 2003$ & 5.75 & $\mathrm{~T}$ \\
\hline & & & $03 / 28 / 2003$ & 5.70 & $\mathrm{~T}$ \\
\hline & & & $05 / 05 / 2003$ & 5.65 & $\mathrm{~S}$ \\
\hline & & & $05 / 07 / 2003$ & 5.65 & $\mathrm{~T}$ \\
\hline & & & $05 / 14 / 2003$ & 5.65 & $\mathrm{~T}$ \\
\hline & & & $06 / 19 / 2003$ & 6.52 & $\mathrm{~S}$ \\
\hline & & & $08 / 14 / 2003$ & 7.94 & $\mathrm{~T}$ \\
\hline & & & $11 / 20 / 2003$ & 7.94 & $\mathrm{~T}$ \\
\hline & & & $01 / 30 / 2004$ & 7.40 & $\mathrm{~T}$ \\
\hline \multirow[t]{2}{*}{7} & 024N018E07G001M & 395737120001301 & $11 / 20 / 2003$ & 9.76 & $S$ \\
\hline & & & $01 / 30 / 2004$ & 9.55 & $\mathrm{~S}$ \\
\hline
\end{tabular}


Estimates of Natural Ground-Water Discharge and Characterization of Water Quality in Dry Valley, 2002-2003

Appendix-Selected ground-water levels measured in wells, Dry Valley, west-central Nevada--Continued

\begin{tabular}{|c|c|c|c|c|c|}
\hline $\begin{array}{c}\text { Site } \\
\text { number } \\
\text { (fig. 2) }\end{array}$ & Local identification & Standard identification & $\begin{array}{l}\text { Water-level } \\
\text { date }\end{array}$ & $\begin{array}{l}\text { Water level } \\
\text { below } \\
\text { land surface }\end{array}$ & $\begin{array}{l}\text { Measurement } \\
\text { method }\end{array}$ \\
\hline \multirow{31}{*}{8} & \multirow{31}{*}{095 N24 E18 17DAAB2 } & \multirow{31}{*}{395737119595502} & $11 / 10 / 2002$ & 9.00 & $\mathrm{R}$ \\
\hline & & & $11 / 14 / 2002$ & 7.62 & $\mathrm{~T}$ \\
\hline & & & $11 / 19 / 2002$ & 7.45 & $\mathrm{~T}$ \\
\hline & & & $12 / 19 / 2002$ & 6.48 & $\mathrm{~T}$ \\
\hline & & & $12 / 23 / 2002$ & 6.35 & $\mathrm{~T}$ \\
\hline & & & $12 / 30 / 2002$ & 6.28 & $\mathrm{~T}$ \\
\hline & & & $01 / 07 / 2003$ & 6.08 & $\mathrm{~T}$ \\
\hline & & & $01 / 21 / 2003$ & 5.76 & $\mathrm{~T}$ \\
\hline & & & $01 / 22 / 2003$ & 5.77 & $\mathrm{~T}$ \\
\hline & & & $01 / 23 / 2003$ & 6.53 & $\mathrm{~T}$ \\
\hline & & & $02 / 12 / 2003$ & 5.50 & $\mathrm{~T}$ \\
\hline & & & 03/06/2003 & 4.95 & $\mathrm{~T}$ \\
\hline & & & $03 / 28 / 2003$ & 4.50 & $\mathrm{~T}$ \\
\hline & & & $05 / 01 / 2003$ & 5.05 & $\mathrm{~T}$ \\
\hline & & & $05 / 01 / 2003$ & 5.03 & $\mathrm{~T}$ \\
\hline & & & 05/01/2003 & 5.04 & $\mathrm{~T}$ \\
\hline & & & $05 / 01 / 2003$ & 5.04 & $\mathrm{~T}$ \\
\hline & & & $05 / 01 / 2003$ & 5.04 & $\mathrm{~T}$ \\
\hline & & & $05 / 01 / 2003$ & 5.24 & $\mathrm{~T}$ \\
\hline & & & $05 / 14 / 2003$ & 6.97 & $\mathrm{~T}$ \\
\hline & & & $06 / 19 / 2003$ & 7.10 & $\mathrm{~S}$ \\
\hline & & & $07 / 01 / 2003$ & 7.24 & $\mathrm{~T}$ \\
\hline & & & $07 / 08 / 2003$ & 7.07 & $\mathrm{~T}$ \\
\hline & & & $07 / 10 / 2003$ & 7.91 & $\mathrm{~T}$ \\
\hline & & & $07 / 10 / 2003$ & 7.90 & $\mathrm{~T}$ \\
\hline & & & 07/10/2003 & 7.92 & $\mathrm{~T}$ \\
\hline & & & $07 / 10 / 2003$ & 7.95 & $\mathrm{~T}$ \\
\hline & & & $07 / 16 / 2003$ & 11.00 & $\mathrm{~T}$ \\
\hline & & & $08 / 14 / 2003$ & 9.71 & $\mathrm{~T}$ \\
\hline & & & $11 / 20 / 2003$ & 7.38 & $\mathrm{~T}$ \\
\hline & & & $01 / 30 / 2004$ & 7.01 & $\mathrm{~T}$ \\
\hline \multirow[t]{15}{*}{9} & \multirow[t]{15}{*}{095 N24 E18 07DAAB1 } & \multirow[t]{15}{*}{395737119595501} & $11 / 10 / 2002$ & 9.00 & $\mathrm{R}$ \\
\hline & & & $11 / 14 / 2002$ & 10.37 & $\mathrm{~T}$ \\
\hline & & & $11 / 19 / 2002$ & 10.59 & $\mathrm{~T}$ \\
\hline & & & $12 / 19 / 2002$ & 10.20 & $\mathrm{~T}$ \\
\hline & & & $12 / 23 / 2002$ & 10.12 & $\mathrm{~T}$ \\
\hline & & & $12 / 30 / 2002$ & 10.10 & $\mathrm{~T}$ \\
\hline & & & $01 / 07 / 2003$ & 9.88 & $\mathrm{~T}$ \\
\hline & & & $01 / 21 / 2003$ & 9.79 & $\mathrm{~T}$ \\
\hline & & & $01 / 22 / 2003$ & 9.81 & $\mathrm{~T}$ \\
\hline & & & $01 / 23 / 2003$ & 10.70 & $\mathrm{~T}$ \\
\hline & & & $02 / 12 / 2003$ & 9.71 & $\mathrm{~T}$ \\
\hline & & & $03 / 06 / 2003$ & 9.76 & $\mathrm{~T}$ \\
\hline & & & $03 / 28 / 2003$ & 8.80 & $\mathrm{~T}$ \\
\hline & & & $05 / 01 / 2003$ & 15.52 & $\mathrm{~T}$ \\
\hline & & & $05 / 01 / 2003$ & 10.25 & $\mathrm{~T}$ \\
\hline
\end{tabular}


Appendix-Selected ground-water levels measured in wells, Dry Valley, west-central Nevada--Continued

\begin{tabular}{|c|c|c|c|c|c|}
\hline $\begin{array}{c}\text { Site } \\
\text { number } \\
\text { (fig. 2) }\end{array}$ & Local identification & Standard identification & $\begin{array}{c}\text { Water-level } \\
\text { date }\end{array}$ & $\begin{array}{c}\text { Water level } \\
\text { below } \\
\text { land surface }\end{array}$ & $\begin{array}{l}\text { Measurement } \\
\text { method }\end{array}$ \\
\hline & & & $05 / 01 / 2003$ & 10.78 & $\mathrm{~T}$ \\
\hline & & & $05 / 01 / 2003$ & 12.59 & $\mathrm{~T}$ \\
\hline & & & $05 / 01 / 2003$ & 14.03 & $\mathrm{~T}$ \\
\hline & & & $05 / 14 / 2003$ & 10.14 & $\mathrm{~T}$ \\
\hline & & & $06 / 19 / 2003$ & 11.25 & $\mathrm{~S}$ \\
\hline & & & $07 / 01 / 2003$ & 10.43 & $\mathrm{~T}$ \\
\hline & & & $07 / 08 / 2003$ & 10.90 & $\mathrm{~T}$ \\
\hline & & & $07 / 10 / 2003$ & 12.44 & $\mathrm{~T}$ \\
\hline & & & $07 / 10 / 2003$ & 12.26 & $\mathrm{~T}$ \\
\hline & & & $07 / 10 / 2003$ & 12.19 & $\mathrm{~T}$ \\
\hline & & & $07 / 10 / 2003$ & 12.57 & $\mathrm{~T}$ \\
\hline & & & $07 / 16 / 2003$ & 8.19 & $\mathrm{~T}$ \\
\hline & & & $08 / 14 / 2003$ & 11.67 & $\mathrm{~T}$ \\
\hline & & & $11 / 20 / 2003$ & 10.69 & $\mathrm{~T}$ \\
\hline & & & $01 / 30 / 2004$ & 10.39 & $\mathrm{~T}$ \\
\hline \multirow[t]{10}{*}{10} & 095 N24 E18 08CBAA1 & 395736119593501 & $09 / 18 / 2002$ & 4.00 & $\mathrm{R}$ \\
\hline & & & $09 / 23 / 2002$ & 3.74 & $\mathrm{~T}$ \\
\hline & & & $11 / 19 / 2002$ & 3.38 & $\mathrm{~T}$ \\
\hline & & & $12 / 30 / 2002$ & 2.66 & $\mathrm{~T}$ \\
\hline & & & $01 / 07 / 2003$ & 2.43 & $\mathrm{~T}$ \\
\hline & & & $03 / 06 / 2003$ & 2.28 & $\mathrm{~T}$ \\
\hline & & & $05 / 01 / 2003$ & .98 & $\mathrm{~T}$ \\
\hline & & & $08 / 14 / 2003$ & 3.39 & $\mathrm{~T}$ \\
\hline & & & $11 / 20 / 2003$ & 3.82 & $\mathrm{~T}$ \\
\hline & & & $01 / 30 / 2004$ & 3.28 & $\mathrm{~T}$ \\
\hline \multirow[t]{16}{*}{11} & 095 N24 E18 08CBAA2 & 395735119593401 & $09 / 18 / 2002$ & 4.00 & $\mathrm{R}$ \\
\hline & & & $09 / 23 / 2002$ & 3.61 & $\mathrm{~T}$ \\
\hline & & & $11 / 19 / 2002$ & 3.20 & $\mathrm{~T}$ \\
\hline & & & $12 / 19 / 2002$ & 2.70 & $\mathrm{~T}$ \\
\hline & & & $12 / 30 / 2002$ & 2.33 & $\mathrm{~T}$ \\
\hline & & & $01 / 07 / 2003$ & 2.16 & $\mathrm{~T}$ \\
\hline & & & $01 / 21 / 2003$ & 1.97 & $\mathrm{~T}$ \\
\hline & & & $01 / 22 / 2003$ & 1.99 & $\mathrm{~T}$ \\
\hline & & & $02 / 12 / 2003$ & 1.79 & $\mathrm{~T}$ \\
\hline & & & 03/06/2003 & 1.53 & $\mathrm{~T}$ \\
\hline & & & $03 / 28 / 2003$ & 1.65 & $\mathrm{~T}$ \\
\hline & & & $05 / 01 / 2003$ & 1.85 & $\mathrm{~T}$ \\
\hline & & & $05 / 07 / 2003$ & 1.93 & $\mathrm{~T}$ \\
\hline & & & $08 / 14 / 2003$ & 3.53 & $\mathrm{~T}$ \\
\hline & & & $11 / 20 / 2003$ & 3.55 & $\mathrm{~T}$ \\
\hline & & & $01 / 30 / 2004$ & 3.11 & $\mathrm{~T}$ \\
\hline \multirow[t]{5}{*}{12} & 095 N24 E18 09CABB1 & 395735119582401 & $11 / 19 / 2002$ & 24.36 & $\mathrm{~T}$ \\
\hline & & & $01 / 22 / 2003$ & 24.46 & $\mathrm{~T}$ \\
\hline & & & $03 / 06 / 2003$ & 24.32 & $\mathrm{~T}$ \\
\hline & & & $05 / 05 / 2003$ & 24.45 & $\mathrm{~S}$ \\
\hline & & & $06 / 19 / 2003$ & 24.82 & $\mathrm{~S}$ \\
\hline
\end{tabular}


Estimates of Natural Ground-Water Discharge and Characterization of Water Quality in Dry Valley, 2002-2003

Appendix-Selected ground-water levels measured in wells, Dry Valley, west-central Nevada--Continued

\begin{tabular}{|c|c|c|c|c|c|}
\hline $\begin{array}{c}\text { Site } \\
\text { number } \\
\text { (fig. 2) }\end{array}$ & Local identification & Standard identification & $\begin{array}{c}\text { Water-level } \\
\text { date }\end{array}$ & $\begin{array}{c}\text { Water level } \\
\text { below } \\
\text { land surface }\end{array}$ & $\begin{array}{l}\text { Measurement } \\
\text { method }\end{array}$ \\
\hline & & & $08 / 14 / 2003$ & 24.46 & $\mathrm{~T}$ \\
\hline & & & $11 / 20 / 2003$ & 24.98 & $\mathrm{~T}$ \\
\hline & & & $01 / 30 / 2004$ & 25.21 & $\mathrm{~T}$ \\
\hline \multirow[t]{26}{*}{13} & 024N018E07J01M & 395734119595601 & $12 / 27 / 1990$ & 6.00 & $\mathrm{R}$ \\
\hline & & & 02/06/2002 & 10.37 & $\mathrm{~T}$ \\
\hline & & & $08 / 21 / 2002$ & 11.45 & $\mathrm{~T}$ \\
\hline & & & $11 / 19 / 2002$ & 11.40 & $\mathrm{~T}$ \\
\hline & & & $12 / 19 / 2002$ & 11.05 & $\mathrm{~T}$ \\
\hline & & & $12 / 23 / 2002$ & 10.98 & $\mathrm{~T}$ \\
\hline & & & $12 / 30 / 2002$ & 10.91 & $\mathrm{~T}$ \\
\hline & & & $01 / 07 / 2003$ & 10.75 & $\mathrm{~T}$ \\
\hline & & & $01 / 21 / 2003$ & 10.65 & $\mathrm{~T}$ \\
\hline & & & $01 / 23 / 2003$ & 11.24 & $\mathrm{~T}$ \\
\hline & & & $03 / 06 / 2003$ & 10.48 & $\mathrm{~T}$ \\
\hline & & & $03 / 28 / 2003$ & 10.55 & $\mathrm{~T}$ \\
\hline & & & $05 / 01 / 2003$ & 84.50 & $\mathrm{~T}$ \\
\hline & & & 05/01/2003 & 90.95 & $\mathrm{~T}$ \\
\hline & & & $05 / 01 / 2003$ & 89.60 & $\mathrm{~T}$ \\
\hline & & & $05 / 01 / 2003$ & 86.80 & $\mathrm{~T}$ \\
\hline & & & $05 / 01 / 2003$ & 81.50 & $\mathrm{~T}$ \\
\hline & & & $05 / 01 / 2003$ & 63.50 & $\mathrm{~T}$ \\
\hline & & & $05 / 01 / 2003$ & 10.96 & $\mathrm{~T}$ \\
\hline & & & $05 / 14 / 2003$ & 10.69 & $\mathrm{~T}$ \\
\hline & & & $06 / 19 / 2003$ & 12.35 & $\mathrm{~S}$ \\
\hline & & & 07/08/2003 & 12.19 & $\mathrm{~T}$ \\
\hline & & & $07 / 10 / 2003$ & 13.45 & $\mathrm{~T}$ \\
\hline & & & $08 / 14 / 2003$ & 12.92 & $\mathrm{~T}$ \\
\hline & & & $11 / 20 / 2003$ & 11.70 & $\mathrm{~S}$ \\
\hline & & & $01 / 30 / 2004$ & 11.56 & $\mathrm{~T}$ \\
\hline \multirow[t]{15}{*}{14} & 095 N24 E18 07DAAC3 & 395734119595503 & $11 / 05 / 2002$ & 8.00 & $\mathrm{R}$ \\
\hline & & & $11 / 09 / 2002$ & 5.3 & $\mathrm{~T}$ \\
\hline & & & $11 / 11 / 2002$ & 5.7 & $\mathrm{~T}$ \\
\hline & & & $11 / 12 / 2002$ & 8.66 & $\mathrm{~T}$ \\
\hline & & & $11 / 14 / 2002$ & 6.94 & $\mathrm{~T}$ \\
\hline & & & $11 / 19 / 2002$ & 6.94 & $\mathrm{~T}$ \\
\hline & & & $12 / 19 / 2002$ & 6.12 & $\mathrm{~T}$ \\
\hline & & & $12 / 23 / 2002$ & 6.02 & $\mathrm{~T}$ \\
\hline & & & $12 / 30 / 2002$ & 5.90 & $\mathrm{~T}$ \\
\hline & & & $01 / 07 / 2003$ & 5.83 & $\mathrm{~T}$ \\
\hline & & & $01 / 21 / 2003$ & 5.74 & $\mathrm{~T}$ \\
\hline & & & $01 / 22 / 2003$ & 5.72 & $\mathrm{~T}$ \\
\hline & & & $01 / 23 / 2003$ & 6.05 & $\mathrm{~T}$ \\
\hline & & & $02 / 12 / 2003$ & 5.64 & $\mathrm{~T}$ \\
\hline & & & 03/06/2003 & 5.60 & $\mathrm{~T}$ \\
\hline
\end{tabular}


Appendix-Selected ground-water levels measured in wells, Dry Valley, west-central Nevada--Continued

\begin{tabular}{|c|c|c|c|c|c|}
\hline $\begin{array}{c}\text { Site } \\
\text { number } \\
\text { (fig. 2) }\end{array}$ & Local identification & Standard identification & $\begin{array}{c}\text { Water-level } \\
\text { date }\end{array}$ & $\begin{array}{l}\text { Water level } \\
\text { below } \\
\text { land surface }\end{array}$ & $\begin{array}{l}\text { Measurement } \\
\text { method }\end{array}$ \\
\hline & & & $03 / 28 / 2003$ & 5.55 & $\mathrm{~T}$ \\
\hline & & & 05/01/2003 & 5.88 & $\mathrm{~T}$ \\
\hline & & & 05/01/2003 & 5.78 & $\mathrm{~T}$ \\
\hline & & & $05 / 01 / 2003$ & 5.58 & $\mathrm{~T}$ \\
\hline & & & 05/01/2003 & 5.96 & $\mathrm{~T}$ \\
\hline & & & $05 / 01 / 2003$ & 5.68 & $\mathrm{~T}$ \\
\hline & & & 05/01/2003 & 5.58 & $\mathrm{~T}$ \\
\hline & & & 05/01/2003 & 5.75 & $\mathrm{~T}$ \\
\hline & & & $05 / 14 / 2003$ & 6.05 & $\mathrm{~T}$ \\
\hline & & & $06 / 19 / 2003$ & 6.79 & $\mathrm{~S}$ \\
\hline & & & 07/08/2003 & 6.83 & $\mathrm{~T}$ \\
\hline & & & $07 / 10 / 2003$ & 7.43 & $\mathrm{~T}$ \\
\hline & & & 08/14/2003 & 7.46 & $\mathrm{~T}$ \\
\hline & & & $11 / 20 / 2003$ & 7.15 & $\mathrm{~T}$ \\
\hline & & & $01 / 30 / 2004$ & 6.75 & $\mathrm{~T}$ \\
\hline \multirow[t]{29}{*}{15} & 095 N24 E18 07DAAC2 & 395734119595502 & $11 / 05 / 2002$ & 13.00 & $\mathrm{R}$ \\
\hline & & & $11 / 09 / 2002$ & 11.90 & $\mathrm{~T}$ \\
\hline & & & $11 / 11 / 2002$ & 12.20 & $\mathrm{~T}$ \\
\hline & & & $11 / 12 / 2002$ & 15.20 & $\mathrm{~T}$ \\
\hline & & & $11 / 14 / 2002$ & 11.91 & $\mathrm{~T}$ \\
\hline & & & $11 / 19 / 2002$ & 12.46 & $\mathrm{~T}$ \\
\hline & & & $12 / 19 / 2002$ & 8.45 & $\mathrm{~T}$ \\
\hline & & & $12 / 23 / 2002$ & 8.44 & $\mathrm{~T}$ \\
\hline & & & $12 / 30 / 2002$ & 8.43 & $\mathrm{~T}$ \\
\hline & & & 01/07/2003 & 8.18 & $\mathrm{~T}$ \\
\hline & & & $01 / 22 / 2003$ & 7.75 & $\mathrm{~T}$ \\
\hline & & & $01 / 23 / 2003$ & 8.66 & $\mathrm{~T}$ \\
\hline & & & $02 / 12 / 2003$ & 7.51 & $\mathrm{~T}$ \\
\hline & & & 03/06/2003 & 7.51 & $\mathrm{~T}$ \\
\hline & & & $03 / 28 / 2003$ & 7.53 & $\mathrm{~T}$ \\
\hline & & & 05/01/2003 & 12.58 & $\mathrm{~T}$ \\
\hline & & & 05/01/2003 & 11.16 & $\mathrm{~T}$ \\
\hline & & & $05 / 01 / 2003$ & 8.26 & $\mathrm{~T}$ \\
\hline & & & 05/01/2003 & 8.53 & $\mathrm{~T}$ \\
\hline & & & 05/01/2003 & 8.21 & $\mathrm{~T}$ \\
\hline & & & 05/01/2003 & 9.83 & $\mathrm{~T}$ \\
\hline & & & 05/01/2003 & 8.21 & $\mathrm{~T}$ \\
\hline & & & $05 / 14 / 2003$ & 9.32 & $\mathrm{~T}$ \\
\hline & & & 06/19/2003 & 13.87 & $\mathrm{~S}$ \\
\hline & & & 07/08/2003 & 12.71 & $\mathrm{~T}$ \\
\hline & & & 07/10/2003 & 15.44 & $\mathrm{~T}$ \\
\hline & & & 08/14/2003 & 14.59 & $\mathrm{~T}$ \\
\hline & & & $11 / 20 / 2003$ & 11.92 & $\mathrm{~T}$ \\
\hline & & & 01/30/2004 & 11.57 & $\mathrm{~T}$ \\
\hline
\end{tabular}


Estimates of Natural Ground-Water Discharge and Characterization of Water Quality in Dry Valley, 2002-2003

Appendix-Selected ground-water levels measured in wells, Dry Valley, west-central Nevada--Continued

\begin{tabular}{|c|c|c|c|c|c|}
\hline $\begin{array}{c}\text { Site } \\
\text { number } \\
\text { (fig. 2) }\end{array}$ & Local identification & Standard identification & $\begin{array}{c}\text { Water-level } \\
\text { date }\end{array}$ & $\begin{array}{c}\text { Water level } \\
\text { below } \\
\text { land surface }\end{array}$ & $\begin{array}{l}\text { Measurement } \\
\text { method }\end{array}$ \\
\hline \multirow[t]{31}{*}{16} & \multirow[t]{31}{*}{095 N24 E18 07DAAC1 } & \multirow[t]{31}{*}{395734119595501} & $11 / 05 / 2002$ & 16.00 & $\mathrm{R}$ \\
\hline & & & $11 / 09 / 2002$ & 33.40 & $\mathrm{~T}$ \\
\hline & & & $11 / 11 / 2002$ & 38.70 & $\mathrm{~T}$ \\
\hline & & & $11 / 12 / 2002$ & 17.49 & $\mathrm{~T}$ \\
\hline & & & $11 / 14 / 2002$ & 15.40 & $\mathrm{~T}$ \\
\hline & & & $11 / 19 / 2002$ & 15.06 & $\mathrm{~T}$ \\
\hline & & & $12 / 03 / 2002$ & 20.76 & $\mathrm{~T}$ \\
\hline & & & $12 / 19 / 2002$ & 19.43 & $\mathrm{~T}$ \\
\hline & & & $12 / 23 / 2002$ & 19.37 & $\mathrm{~T}$ \\
\hline & & & $12 / 30 / 2002$ & 19.26 & $\mathrm{~T}$ \\
\hline & & & 01/07/2003 & 19.07 & $\mathrm{~T}$ \\
\hline & & & $01 / 21 / 2003$ & 16.39 & $\mathrm{~T}$ \\
\hline & & & $01 / 22 / 2003$ & 17.39 & $\mathrm{~T}$ \\
\hline & & & $01 / 23 / 2003$ & 17.30 & $\mathrm{~T}$ \\
\hline & & & $02 / 12 / 2003$ & 17.24 & $\mathrm{~T}$ \\
\hline & & & 03/06/2003 & 17.09 & $\mathrm{~T}$ \\
\hline & & & $03 / 28 / 2003$ & 17.04 & $\mathrm{~T}$ \\
\hline & & & 05/01/2003 & 17.13 & $\mathrm{~T}$ \\
\hline & & & $05 / 01 / 2003$ & 18.95 & $\mathrm{~T}$ \\
\hline & & & 05/01/2003 & 17.10 & $\mathrm{~T}$ \\
\hline & & & 05/01/2003 & 17.10 & $\mathrm{~T}$ \\
\hline & & & 05/01/2003 & 17.10 & $\mathrm{~T}$ \\
\hline & & & $05 / 01 / 2003$ & 18.37 & $\mathrm{~T}$ \\
\hline & & & 05/01/2003 & 18.23 & $\mathrm{~T}$ \\
\hline & & & $05 / 14 / 2003$ & 16.93 & $\mathrm{~T}$ \\
\hline & & & $06 / 19 / 2003$ & 16.87 & $\mathrm{~S}$ \\
\hline & & & $07 / 08 / 2003$ & 16.98 & $\mathrm{~T}$ \\
\hline & & & $07 / 10 / 2003$ & 16.93 & $\mathrm{~T}$ \\
\hline & & & $08 / 14 / 2003$ & 17.04 & $\mathrm{~T}$ \\
\hline & & & $11 / 20 / 2003$ & 17.19 & $\mathrm{~T}$ \\
\hline & & & $01 / 30 / 2004$ & 16.69 & $\mathrm{~T}$ \\
\hline \multirow[t]{8}{*}{17} & \multirow[t]{8}{*}{095 N24 E18 08CCDC1 } & \multirow[t]{8}{*}{395716119593801} & $06 / 21 / 1973$ & 29.00 & $\mathrm{R}$ \\
\hline & & & $11 / 21 / 2002$ & 34.35 & $\mathrm{~S}$ \\
\hline & & & $01 / 22 / 2003$ & 33.87 & $\mathrm{~S}$ \\
\hline & & & $03 / 06 / 2003$ & 33.50 & $\mathrm{~S}$ \\
\hline & & & 05/05/2003 & 33.30 & $\mathrm{~S}$ \\
\hline & & & $06 / 24 / 2003$ & 34.03 & $\mathrm{~S}$ \\
\hline & & & $08 / 14 / 2003$ & 34.60 & $\mathrm{~S}$ \\
\hline & & & $01 / 30 / 2004$ & 35.40 & $S$ \\
\hline \multirow[t]{2}{*}{18} & \multirow[t]{2}{*}{095 N24 E18 08CDDD1 } & \multirow[t]{2}{*}{395711119591501} & $11 / 20 / 2003$ & dry & $\mathrm{S}$ \\
\hline & & & $01 / 30 / 2004$ & dry & $\mathrm{S}$ \\
\hline \multirow[t]{5}{*}{19} & \multirow[t]{5}{*}{095 N24 E18 15BACC1 } & \multirow[t]{5}{*}{395657119571601} & $11 / 19 / 2002$ & 10.36 & $\mathrm{~T}$ \\
\hline & & & $01 / 22 / 2003$ & 9.48 & $\mathrm{~T}$ \\
\hline & & & 03/06/2003 & 7.02 & $\mathrm{~T}$ \\
\hline & & & $05 / 05 / 2003$ & 7.15 & $\mathrm{~S}$ \\
\hline & & & $06 / 24 / 2003$ & 9.09 & $\mathrm{~S}$ \\
\hline
\end{tabular}


Appendix-Selected ground-water levels measured in wells, Dry Valley, west-central Nevada--Continued

\begin{tabular}{|c|c|c|c|c|c|}
\hline $\begin{array}{c}\text { Site } \\
\text { number } \\
\text { (fig. 2) }\end{array}$ & Local identification & Standard identification & $\begin{array}{l}\text { Water-level } \\
\text { date }\end{array}$ & $\begin{array}{c}\text { Water level } \\
\text { below } \\
\text { land surface }\end{array}$ & $\begin{array}{l}\text { Measurement } \\
\text { method }\end{array}$ \\
\hline & & & 08/14/2003 & 9.89 & $\mathrm{~T}$ \\
\hline & & & $11 / 20 / 2003$ & 10.51 & $\mathrm{~T}$ \\
\hline & & & 01/30/2004 & 10.03 & $\mathrm{~T}$ \\
\hline \multirow[t]{2}{*}{20} & 95 N24 E18 05CCCD1 & 395805119593801 & 01/13/2004 & dry & $\mathrm{T}$ \\
\hline & & & 01/30/2004 & dry & $\mathrm{T}$ \\
\hline \multirow[t]{4}{*}{21} & 095 N24 E18 08BDDD1 & 395753119593201 & $08 / 21 / 2002$ & 16.85 & $\mathrm{~T}$ \\
\hline & & & $08 / 14 / 2003$ & dry & $\mathrm{T}$ \\
\hline & & & 01/13/2004 & 17 & $\mathrm{~T}$ \\
\hline & & & 01/30/2004 & 17.1 & $\mathrm{~T}$ \\
\hline \multirow[t]{4}{*}{22} & 95 N24 E18 08BCBA1 & 395750119593701 & $08 / 21 / 2002$ & dry & $\mathrm{T}$ \\
\hline & & & $08 / 14 / 2003$ & dry & $\mathrm{T}$ \\
\hline & & & $01 / 13 / 2004$ & dry & $\mathrm{T}$ \\
\hline & & & 01/30/2004 & dry & $\mathrm{T}$ \\
\hline \multirow[t]{3}{*}{23} & 95 N24 E18 08ADAD1 & 395745119583901 & 02/06/2002 & 26.83 & $\mathrm{~S}$ \\
\hline & & & $08 / 21 / 2002$ & 27.35 & $\mathrm{~T}$ \\
\hline & & & $01 / 30 / 2004$ & 29.39 & $\mathrm{~T}$ \\
\hline
\end{tabular}


Since 1879, the U.S. Geological Survey has been providing maps, reports, and information to help others who manage, develop, and protect our Nation's water, energy, mineral, land, and biological resources. We help find natural resources, and we supply scientific understanding needed to help minimize or mitigate the effects of natural hazards and the environmental damage caused by human activities. The results of our efforts touch the daily lives of almost everyone. 